University of Texas at El Paso

ScholarWorks@UTEP

Open Access Theses \& Dissertations

2019-01-01

\title{
Fault Kinematics Of The Southern Rio Grande Rift: Exploring The Possibility Of Fault Reactivation
}

Georgina Rodriguez Gonzalez

University of Texas at El Paso

Follow this and additional works at: https://digitalcommons.utep.edu/open_etd

Part of the Geology Commons

\section{Recommended Citation}

Rodriguez Gonzalez, Georgina, "Fault Kinematics Of The Southern Rio Grande Rift: Exploring The Possibility Of Fault Reactivation" (2019). Open Access Theses \& Dissertations. 2895.

https://digitalcommons.utep.edu/open_etd/2895

This is brought to you for free and open access by ScholarWorks@UTEP. It has been accepted for inclusion in Open Access Theses \& Dissertations by an authorized administrator of ScholarWorks@UTEP. For more information, please contact Iweber@utep.edu. 


\title{
FAULT KINEMATICS OF THE SOUTHERN RIO GRANDE RIFT: EXPLORING THE POSSIBILITY OF FAULT REACTIVATION
}

\author{
GEORGINA RODRIGUEZ GONZALEZ \\ Master's Program in Geological Sciences
}

APPROVED:

Jason W. Ricketts, Ph.D., Chair

Terry Pavlis, Ph.D.

Raed AlDouri, Ph.D.

Stephen L. Crites, Jr., Ph.D.

.Dean of the Graduate School 
Copyright (C)

by

Georgina Rodriguez Gonzalez

2019 


\section{DEDICATION}

This thesis is dedicated to every single person that had some type of impact on me throughout my education. Thank you for the knowledge, lessons and joy you brought into my life. 


\title{
FAULT KINEMATICS OF THE SOUTHERN RIO GRANDE RIFT: EXPLORING THE POSSIBILITY OF FAULT REACTIVATION
}

\author{
by \\ GEORGINA RODRIGUEZ GONZALEZ, B.S
}

\author{
THESIS \\ Presented to the Faculty of the Graduate School of \\ The University of Texas at El Paso \\ in Partial Fulfillment \\ of the Requirements \\ for the Degree of \\ MASTER OF SCIENCE \\ Department of Geological Sciences \\ THE UNIVERSITY OF TEXAS AT EL PASO
}

December 2019 


\begin{abstract}
The region in and around the southern Rio Grande rift has experienced a long and complex tectonic history since the Precambrian era. In addition to recording extension directions due to the opening of the Rio Grande rift, faults can also possibly record contractional deformation related to the Laramide orogeny, extension along the boundary of the Mesozoic Chihuahua Trough, and possibly strike - slip movement since the Precambrian related to the Texas Lineament. The northern and central segments of the Rio Grande rift preserve mostly N - S-trending faults, whereas the southern segment preserves NW - SE-trending faults. The main hypothesis to test is that although both fault sets were active during extension of the rift, the NW - SE trending faults may preserve evidence for underlying reactivated older faults, possibly dating back to the Precambrian. Using exposed faults in the southern rift, a paleostrain analysis was performed to determine maximum extension $\left(\mathrm{S}_{1}\right)$ and maximum shortening $\left(\mathrm{S}_{3}\right)$ directions. Fault kinematic data was collected from six mountain ranges in southern New Mexico and western Texas.
\end{abstract}

Results support a model where the entire Rio Grande rift evolved within a general EWdirected extensional stress field. This resulted in extension along NS-trending dip-slip faults in the northern and central segments of the rift. In contrast, in the southern rift EW-directed extension may have been accomplished through reactivation of much older underlying structures in the crust, resulting in NW-trending dip-slip and oblique-slip faults. This observation could help explain the geometric "bend" in the Rio Grande rift as it continues south into Texas and northern Mexico. Further investigation of the kinematics is underway and is critical to understanding the importance of reactivation during continued extension within the southern Rio Grande rift. 


\section{TABLE OF CONTENTS}

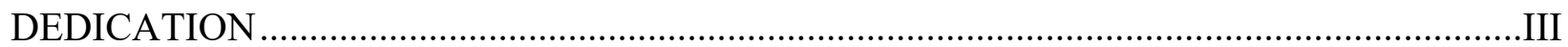

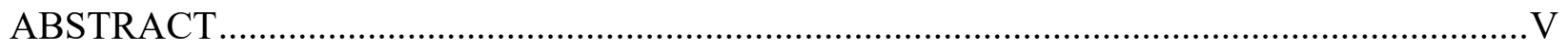

TABLE OF CONTENTS .................................................................................................

LIST OF FIGURES ...............................................................................................

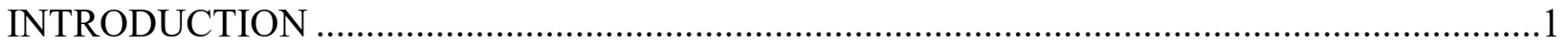

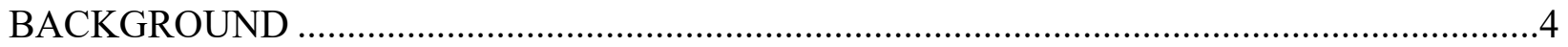

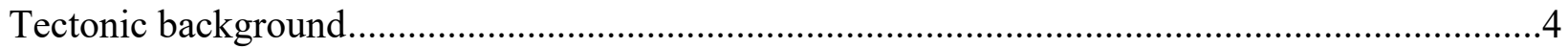

Texas Lineament (Precambrian to Mesozoic?).............................................................4

Western Texas Lineament................................................................................4

Eastern Texas Lineament.......................................................................................

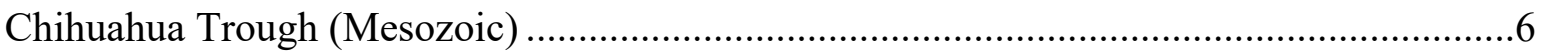

Laramide orogeny (Late Cretaceous $\sim 80 \mathrm{Ma}$ - Late Eocene $\sim 40 \mathrm{Ma}$ )............................ 7

Rio Grande rift (Early oligocene $~ 35 / 32 \mathrm{Ma}$ - present) .............................................

Previous fault kinematic studies done in the Rio Grande rift .................................................. 10

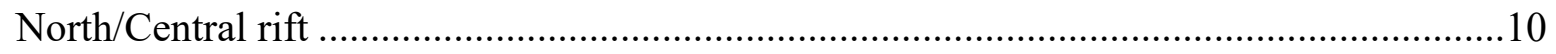

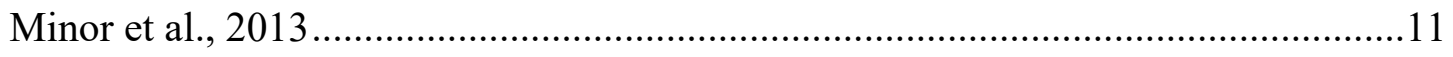

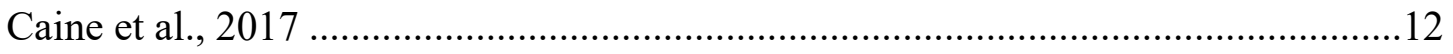

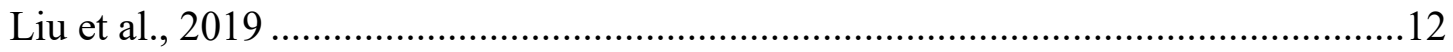

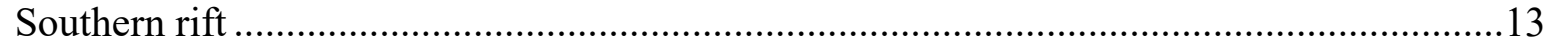

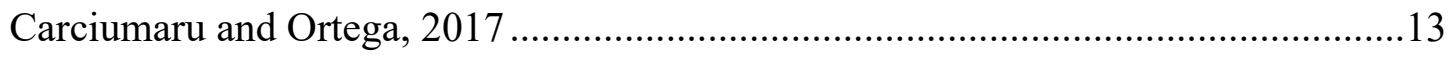

Common models proposed to explain changes in fault strike through the Rio Grande rift..........14

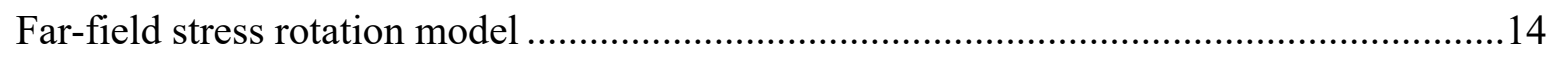

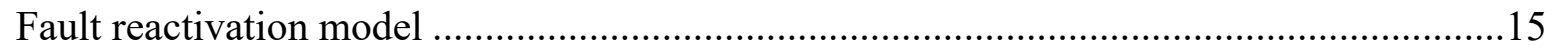


METHODS

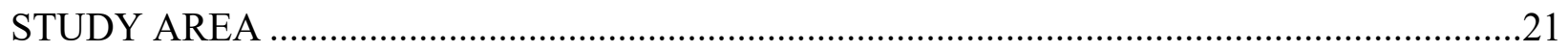

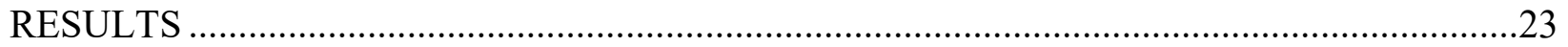

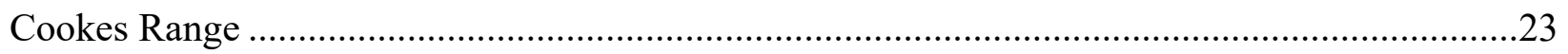

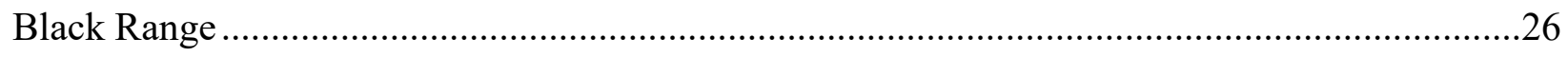

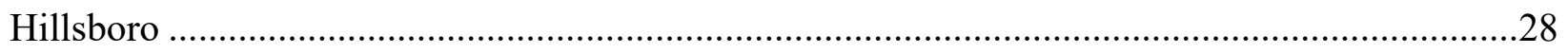

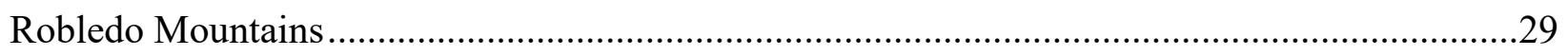

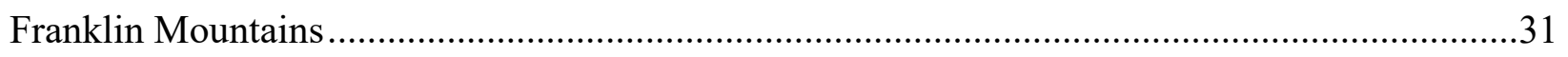

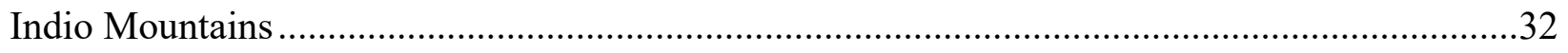

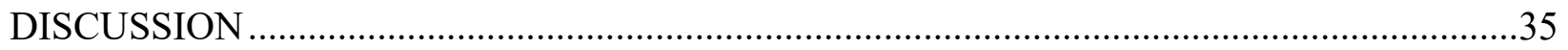

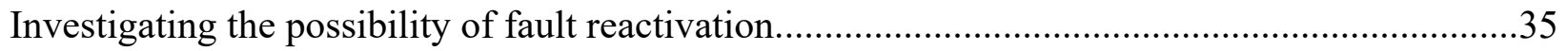

Comparing kinematic data from the southern and northern/central Rio Grande rift............36

Expected fault strike and rake orientations for the rift .....................................................36

Comparing compiled and collected data for both segments of the Rio Grande rift ..............37

Comparing 2-D and 3-D histograms for both segments of the rift ........................................39

Collected and compiled data for both segments of the rift ...................................................40

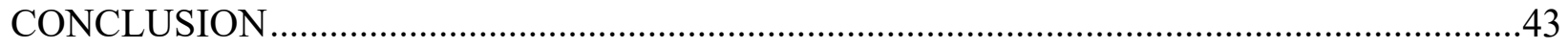

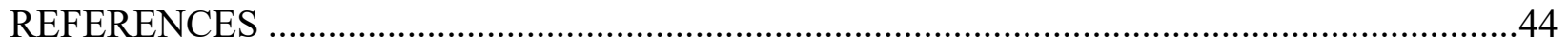

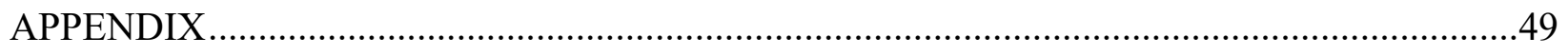

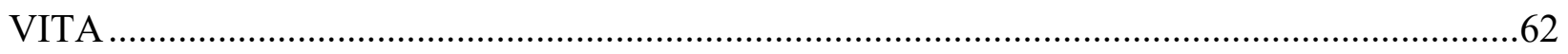




\section{LIST OF FIGURES}

Fig. 1 Location of Rio Grande rift and other geologic features of the region. The rectangles represent the two segments of the rift: central/northern and southern rift.

Fig. 2 Trend of previous tectonic events throughout southern New Mexico. Texas lineament green, Chihuahua trough - yellow, Laramide orogeny - blue, Rio Grande rift - red Compiled from: Mack and Giles, 2004. 2

Fig. 3 Diagram illustrating different shear sense indicators that can be identified off of fault planes.

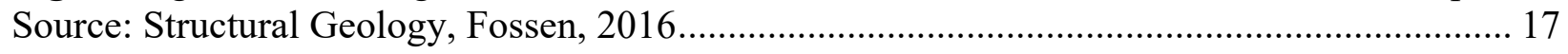

Fig. 4 Lower hemisphere stereonet using hypothetical measurements to illustrate the different components of the study's results................................................................................ 18

Fig. 5 Geologic map of the southern Rio Grande rift region. The two study areas are marked by the black rectangles and the six ranges are labeled by name................................................ 22

Fig. 6 Fault data for the Cookes Range. The overall direction of extension is E-W................. 26

Fig. 7 Fault plane in the Black Range with cross-cutting slickenlines.................................... 27

Fig. 8 Fault data for the Black Range. The overall direction of extension is E-W. Fault population 2 suggests N-S extension and E-W contraction.................................................................. 28

Fig. 9 Fault data for the Hillsboro Mountains. The overall direction of extension is E-W......... 29

Fig. 10 Fault data for the Robledo Mountains. The overall direction of extension is N-S although fault population 2 shows mostly E-W extension. ........................................................... 30

Fig. 11 Fault data for the Franklin Mountains. The overall direction of extension is SE-NW. The data on the "rotated" stereonets still suggests SE-NW extension.......................................... 32

Fig. 12 Fault data for the Franklin Mountains. The overall direction of extension is SE-NW. The data on the "rotated" stereonets still suggests SE-NW extension.............................................. 33

Fig. 13 Histogram showing expected fault orientation through the rift. $\mathrm{X}$ axis- Fault strike (vertical bars), Y axis- Rake (horizontal bars). Data is expected to plot at the intersection of the bars and should shift from N-S normal faults (north rift) to NW-SE oblique faults (south rift).............. 37 Fig. 14 Histograms showing expected fault orientation for the rift. X axis - strike, Y axis - rake. A) Scatter plots from northern/central rift overlaying the expected measurements bars. Data plot as 3 discrete bull's eyes at the intersection of the bars (as expected). B) Data collected from the southern rift (color coded by range) overlaying data from the northern rift (black dots) and bars. The is a shift in data from more N-S normal faults to NW-SE oblique faults, highlighted for the red arrow. 39

Fig. 15 A and C: 3-D Histograms fault data for the rift. B and D: bird-s eye view of the 3-D histograms. X axis - strike, $\mathrm{Y}$ axis - rake. A and B: fault data for the northern rift plots as 3 discrete bull's eyes- indicating NW-trending normal faults. C and D: data for the southern rift spreads out towards more NW-trending oblique slip faults (highlighted by the white arrows)................... 40 Fig. 16 Histograms and kernel density estimations showing rake trends throughout the rift. X: fault rake, Y: number of measurements. A) Central/northern: a single peak in rake data at $90^{\circ}$, indicating pure normal $\left(90^{\circ}\right)$ faults formed under E-W extension B) Southern: a similar peak to the norther rift at $96^{\circ}$ and a secondary peak at $131^{\circ}$, indicating pure normal and oblique slip $\left(135^{\circ}-180^{\circ}\right)$ faults formed under E-W extension. 41 


\section{INTRODUCTION}

The Rio Grande rift is a north

- south trending continental rift that

extends from central Colorado down

to southern New Mexico and into

western Texas and northern

Chihuahua (Fig. 1). Although it is

debatable, a general consensus is that

extension began about $32 \mathrm{Ma}$ in New

Mexico based on paleostress

orientation from radiometrically

dated dikes (K-Ar dating) (Aldrich et

al., 1986). Extension rates have

slowed since approximately $10 \mathrm{Ma}$

based on ages of sedimentary basin

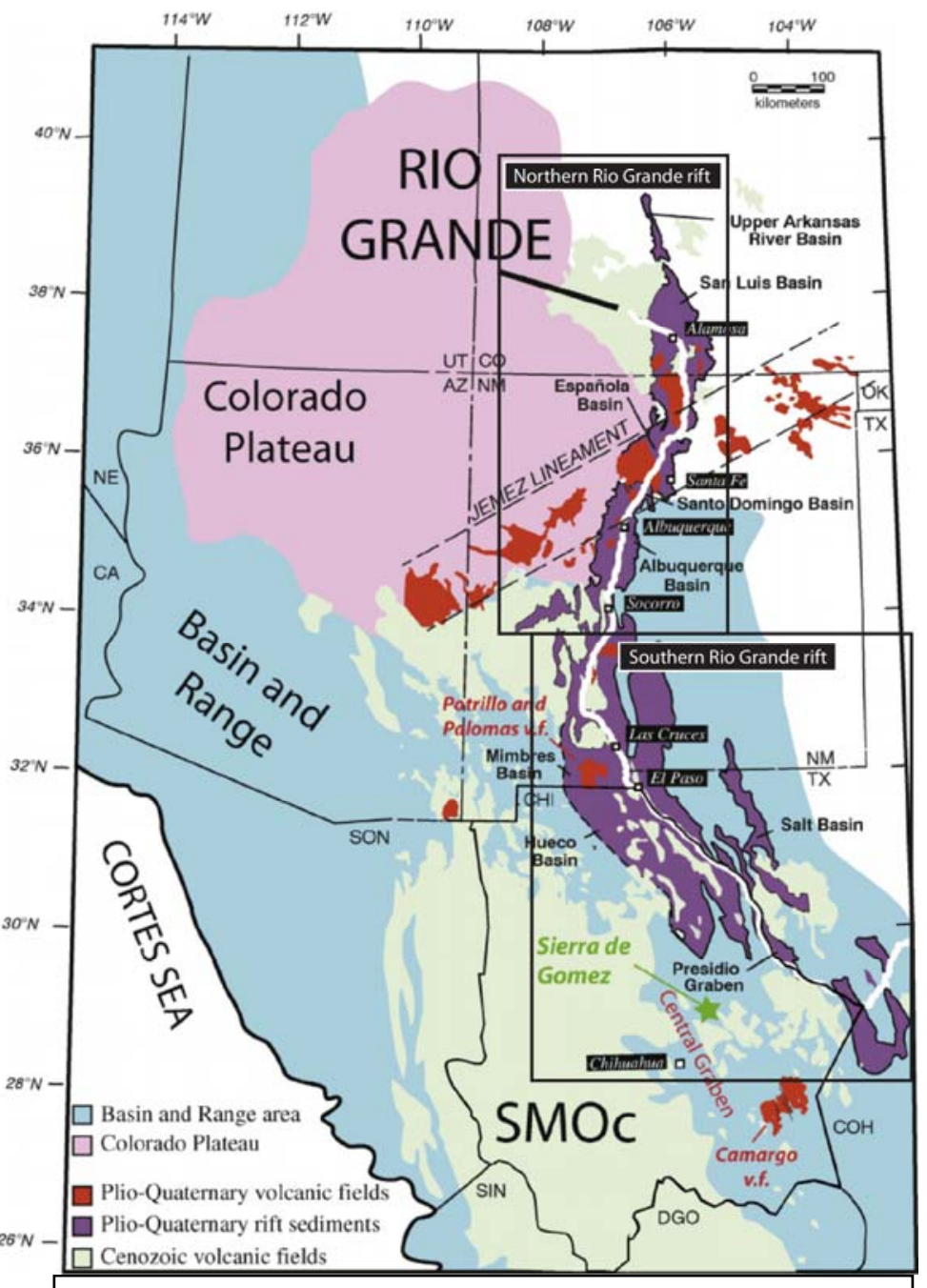

fill (e.g. Baldridge et al., 1980; Ingersoll

et al., 1990) and thermochronologic

analysis (Kelley and Chapin, 1997,

Fig. 1 Location of Rio Grande rift and other geologic features of the region. The rectangles represent the two segments of the rift: central/northern and southern rift.

Modified from J. Villareal Fuentes et al., 2016

House et al., 2003; Landman and

Flowers, 2013; Ricketts et al., 2015, 2016). Although extension has slowed, the rift is still active based on recent and ongoing GPS studies (Berglund et al., 2012; Murray et al., 2018), deformed travertine deposits (Ricketts et al., 2014), and paleoseismology work (McCalpin and Harrison, 2000; Machette et al., 1999). 
The northern/central segment of the rift, extending south as far as Socorro, New Mexico, is characterized by N-S trending basins bounded by N-S trending normal faults. A narrow rift geometry is composed of a series of north-trending half grabens (axial basins) (Liu et al., 2019). In the northern/central, rift axial basins are bounded by regional-scale normal faults at mountain fronts and are separated from adjacent basins by transfer faults and zones of accommodation (Muehlberger, 1979; Faulds and Varga, 1998; Kelson et al., 2004; Koning et al., 2004; Minor et al., 2013).

In contrast, the southern segment of the rift is characterized by NW-SE trending basins that are bounded by NWSE trending faults. This trend is parallel to the

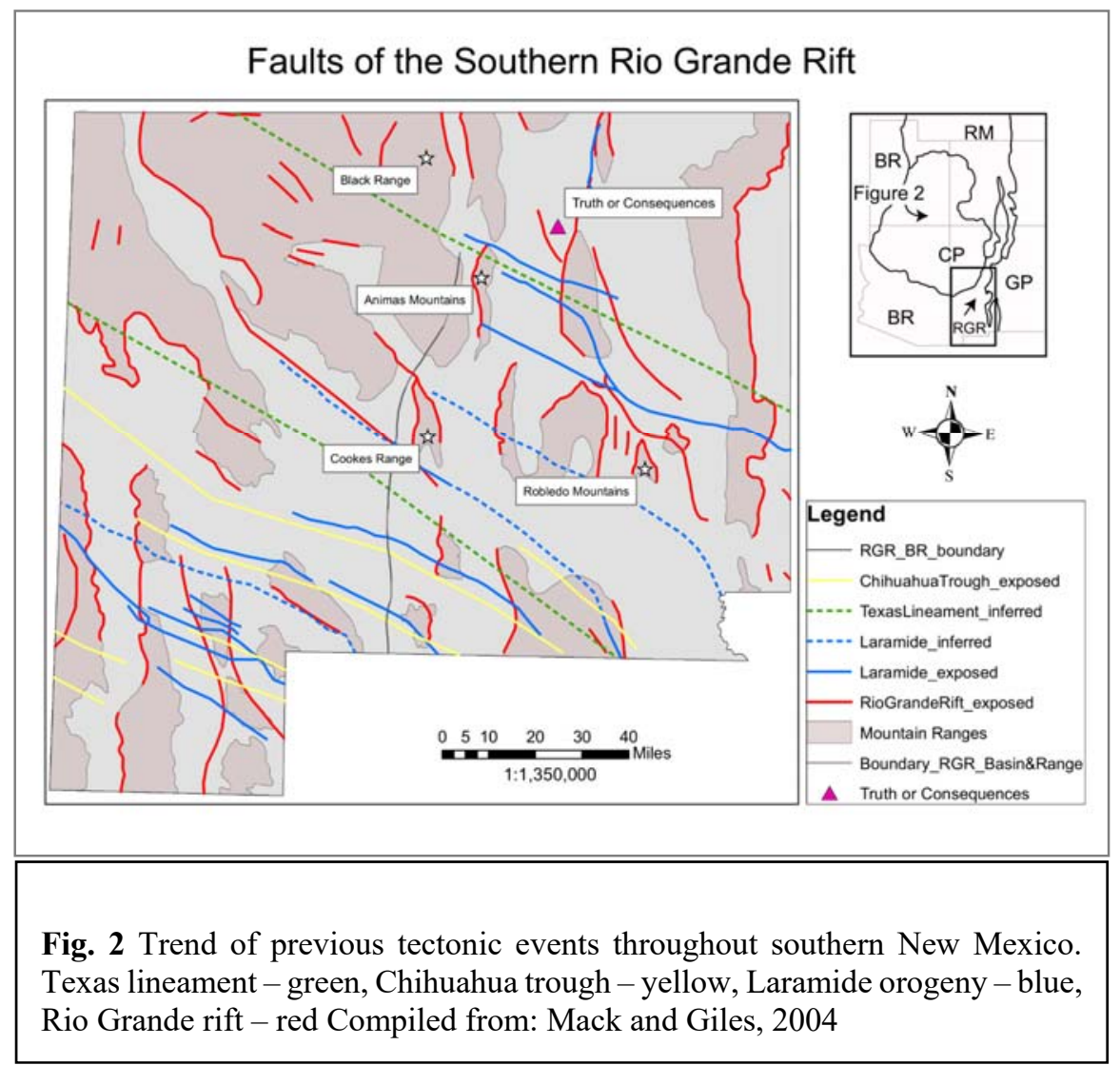
trend of older tectonic events such as the trend of Laramide faults and basins (Seager, 1984), the trend of the Chihuahua Mesozoic Trough (Haenggi, 2002) and the trend of the long-recognized Texas Lineament (King, 1969), which likely has Precambrian ancestry and has been reactivated multiple times (Fig. 2).

Most fault kinematic studies for the Rio Grande rift have been performed in the northern/central portion of the rift. Studies indicate that basins and faults in this segment of the rift 
formed under an E-W extension regime (Aldrich et al., 1986). Very little fault kinematic data has been collected for the southern portion of the rift. Existing studies have focused on understanding the importance of scattered low-angle normal faults throughout southern New Mexico (Carciumaru and Ortega, 2017). Fault kinematic studies with the research objective of understanding patterns of extension in the southern rift are virtually non-existent. There are 2 models that attempt to explain why there is a change in orientation of the rift, at the latitude of El Paso, TX.

1. The NW-SE trending faults and basins formed under a NE-SW regime of extension (e.g. Zoback et al., 1981). Such a stress field would be expected to produce NWtrending normal faults with rake measurements of $90^{\circ}$.

2. The entire rift formed under regional E-W extension, but the southern segment of the rift reactivated older, underlying structures during extension (Morgan_1986). This scenario would likely result in slip along NW- trending faults with oblique sense of slip.

In this study we describe new fault kinematic data from the southern segment of the Rio Grande rift in southern New Mexico and western Texas. These new data are then compared to a compilation of fault kinematic data from the central and northern segments of the rift to further understand patterns of extension during the development of the Rio Grande rift and test between competing hypotheses. The data show significant differences between the central and southern segments of the rift, and support a model where the southern rift reactivated older existing structures due to EW extension. 


\section{BACKGROUND}

\section{Tectonic background}

The region in and around the southern Rio Grande rift has experienced a long and complex tectonic history since the Precambrian. Although a thorough synthesis of these various tectonic events is beyond the scope of this thesis, some of the more prominent periods of deformation that are likely recorded in exposed faults throughout the region are highlighted below.

\section{Texas Lineament (Precambrian to Mesozoic?)}

The Texas Lineament (Fig. 2) is hypothesized to extend from the Transverse Ranges of southern California to the Gulf of Mexico (King, 1937) with left lateral strike - slip motion (Hildebrand, 2015). These features are characterized by a remarkable alignment of geological or topographical features, too precise to be coincidental. Structural features north of the lineament are the Rio Grande rift, Colorado Plateau, the High Planes province and Ouachita - Marathon orogenic belt. It has been proposed that the southwestern edge of the North American craton is a product of rifting approximately $1400 \mathrm{Ma}$ (Sears and Price, 1978). This ancestral boundary is thought to separate a cratonic margin on the north from accreted terrain on the south (Sears and Price, 1978). This region, along with the Cordilleran Belt of western North America, has accreted blocks but has never undergone continent - continent collision since the rifting event (Muehlberger, 1980). There has been no paleostress analysis to document the kinematics of the few identified faults that comprise the lineament, mostly because there are very few faults that can be directly related to the Texas Lineament. Rather, the Texas Lineament is inferred from various geologic data, and can be subdivided in eastern and western segments, as described below.

\section{Western Texas Lineament}

Evidence supporting the existence of the Texas Lineament is preserved in southeastern Arizona, where Wertz (1970) document a belt of WNW-trending fracture sets with different lengths and orientations. The belt extends $100-130 \mathrm{~km}$ as a whole, without any similar structural 
trends to the north or south. The strands of this belt, or lineament, appear to be broken showing a slight concavity in the northeast. Several of the long segments along the belt indicate that there has been some scissor movement. A downthrown block is present in one location on one side of a major fault, then a downthrown block is located approximately a hundred miles away, on the other side of the same fault (Wertz, 1970). It has been proposed that such deep faults may be of wrench type (Moody and Hill, 1956), although they are common and the reversal of apparent dip - slip replacement occurs where zones of transcurrent movement cuts obliquely into existing folds.

\section{Eastern Texas Lineament}

Previous studies using LANDSTAT imagery suggest that the eastern section of the Texas Lineament, within the corridor between Van Horn and Sierra Blanca, TX, shows recurrent movement that separates more stable crust on the north from less stable crust on the south (Muehlberger, 1980). The northern stable platform is a Permian and lower Cretaceous thin carbonate shelf on Precambrian rocks in the Diablo Plateau. The thinner crust to the south is a mobile subsiding trough comprising thick Cretaceous carbonates and clastics on Mesozoic evaporite within the Chihuahua Tectonic belt (thrusted northeastward against the margin of the platform during the Laramide orogeny). Dip-slip movement has been extensively verified. Strike - slip movement has been documented episodically although it has been observed that the amount of slip necessary to produce the observed structural patterns is less than previous studies concluded from the western portion of the lineament (kilometers, rather than hundreds of kilometers) (Muehlberger, 1980).

The East Texas Lineament is further described as an abrupt termination or bend in the strike of Rio Grande rift basins. Late Cenozoic structures, such as the southern ends of grabens related to Rio Grande rift, extend into the corridor between Van Horn and Sierra Blanca. These grabens end abruptly or turn southeast along the northern border of the Texas Lineament (Hueco Bolson 
and Salt Basin). While some suggest the Texas Lineament has Precambrian ancestry (Muehlberger, 1980), many of the features used to describe it can also be attributed to later tectonic events.

\section{Chinuahua Trough (Mesozoic)}

Located in the northeastern state of Chihuahua and adjacent parts of Texas and New Mexico, the Chihuahua Trough has undergone deformation from the late Mesozoic to Quaternary (Haenggi, 2002) (Fig. 2). Haenggi (2002) proposed that Chihuahua trough formed during a relative counterclockwise rotation of the North American Plate (159 to $156 \mathrm{Ma}$ ) as a right lateral pull apart basin. This interpretation is problematic, however, given the more widespread view that this period saw sinistral motion between the SW margin of North America and Gondwana, prior to the opening of the south Atlantic (Anderson, 2005; Amato et al., 2009). Throughout the remainder of the Jurassic to middle Cretaceous time, there was little change in the basin geometry. Following the development of the basin and its adjacent platforms, a marine regression event throughout eastern Chihuahua occurred during the Tithonian and Neocomian time, resulting in extensive evaporite deposits (Haenggi, 2002). Near the end of Aptian time, tectonic activity began to subside. This caused the seas to transgress onto adjacent platform areas until the middle Albian time, when the sea had progressed onto previously exposed areas. Through this period, the Chihuahua Trough became a region of shallow water carbonate deposition known as the Cretaceous Sea. Retreat of the sea can be identified in the transition from marine to non - marine beds.

The present northwestern section of the trough (southern NM, west Texas and northern Chihuahua) is characterized by normal faults trending from N - S to NW - SE (Haenggi, 2002). The presence of two extensive left lateral strike - slip faults striking N-S to NW - SE have been

proposed and have been described as late Oligocene/early Miocene wrench fault system in 
northern Mexico which show displacements of tens of kilometers (Enguiluz de A., 1984). This argument is based on fracture, flexures, dislocated structures, geomorphic features and alignment of plutons. One of the hypothetical strike-slip faults is located within the area of interest of this project, striking from western El Paso, TX to eastern Chihuahua City.

\section{LARAMIDE OROGENy (LATE CRETACEOUS 80 MA - LATE EOCENE 40 MA)}

The Laramide orogeny (late Cretaceous - middle Eocene) caused regional deformation and is characterized by general uplift of basement rock relative to adjacent syn-orogenic basins (Seager, 1984; 2004). During the Late Cretaceous, oceanic lithosphere was subducting beneath the western boundary of North America. At approximately $80 \mathrm{Ma}$, the dip of the Farallon plate shallowed due to subduction of a thick, buoyant section of oceanic lithosphere (Liu et al., 2010), which drove deformation inland as far as central Colorado and New Mexico. As the Farallon plate was undergoing flat slab subduction along the southern part of the North American plate, compressional stresses migrated to the interior of the continent producing a regional pattern of uplifts and basins Seager, 1984). Uplifts generally trend west - northwest, are asymmetric, and are bounded by steeply dipping reverse faults along the northeast margins (Seager, 1984). The first stages of the Laramide (late Cretaceous - late Paleocene) shows evidence of east - northeast directed compression. The later stages (latest Paleocene - middle Eocene) indicate northeast compression. Major uplift margins near Las Cruces suggest that $\sigma_{1}$ (greatest principal stress) was oriented more north - northeast, closer to late stages of the Laramide rather than the earlier stages (Chapin and Cather, 1983).

Due to compression from the Laramide Orogeny, the Chihuahua Trough was inverted to form the Chihuahua Tectonic Belt (Haenggi, 2002). Left lateral transpression reactivated movement 
along the pre-existing fabric on the North American block (Haenggi, 2002). In the eastern areas of the basin (the evaporite section), basin - boundary - faults were reactivated as Laramide reverse faults, with probable left lateral component motion, along with the development of mild ancestral folds. The amplification of folds in post - evaporite rocks was caused by the flow of evaporites towards the crests of anticlines. In the northwestern portion of the trough located in southern New Mexico, structures suggest NE - SW oriented compression and development of minor SW directed thrusting towards the adjacent platforms. Precambrian and Paleozoic formations were thrusted, therefore all faulting can be interpreted as a product of faulted basement, rather than superficial deformation. Laramide deformation ceased $\sim 40 \mathrm{Ma}$, possibly $\sim 30 \mathrm{Ma}$, in the southern New Mexico region; when the Farallon plate steepened, delaminated, and ultimately foundered into the asthenosphere (Copeland et al., 2017; Coney and Reynolds, 1977; Humphreys, 1995, 2009; Dickinson, 2009).

\section{RIO GRANDE RIFT (EARLY OLIGOCENE 35/32 MA - PRESENT)}

The Rio Grande rift is one of the world's active continental rift systems (Morgan, 1986). It is characterized by a series of asymmetrical grabens that extends more than 1,000 kilometers from central Colorado and into Chihuahua, Mexico (Fig. 2).

Following the termination of the Laramide Orogeny, most of southern New Mexico was topographically characterized by a NW-SE trending series of basement block uplifts and basins (Morgan, 1986). At about 35 Ma, Tertiary magmatism was prominent in southwestern New Mexico, mostly as eruptions of large ash flow tuffs from widespread calderas. Individual episodes of volcanism in the region suggests that neither extension nor compression produced the 
topography that controlled the distribution of volcanic rocks. The orientation of stresses during the middle Tertiary volcanism is still debated.

Structural development of the rift occurred during two phases. In contrast to the wellstudied and understood younger stages of rifting, the early history of the rift is still widely debated (Liu et al., 2019). Rifting began at $\sim 32 \mathrm{Ma}$ in the southern portion of the rift, during the earlier phase of regional extension (Chapin, 1979) and lasted $\sim 10-12$ m.y. It is suggested that this first phase of extension was directed NE-SW directed in the southern rift. The onset of extension in the Basin and Range in southern Arizona, west of the Rio Grande rift, correlated to the onset of extension in the Rio Grande rift. It is important to note that the rates of extension were much higher in the Basin and Range but were also unequivocally NE-SW directed (Zoback, 1980). By $26 \mathrm{Ma}$ the developing rift had "thinned-out" the crust sufficiently to form broad, shallow basins which were filled by mafic lava flows, volcanic ash and alluvial fill. The crust of the Rio Grande rift had been moderately thinned and the depth of the Moho ranges from $45 \mathrm{~km}$ under the rift flanks to 33 $\mathrm{km}$ under the rift axis (Olsen et al., 1987). Seismic and structural studies indicate that the brittleductile transition is at depths $-15 \mathrm{~km}$ except for major volcanic fields where it ranges from 2-3 km. From 20 to 13 Ma there was a pause in magmatism (Morgan_1986). This period of declined tectonic and volcanic activity was followed by the second phase of extension from $\sim 10$ to 3 Ma. The earlier extension phase is characterized by extensive low-angle normal faulting which was later offset by high-angle normal faults during the second phase. The far-field stress "clockwise" rotation models proposed by Aldrich et al. (1986) suggests that the regional extension axes rotated during the early Miocene from WSW-ENE to WNW - ESE (Aldrich et al., 1986). Although the stress rotation model is applicable to the southern rift, it lacks data from the northern segment of 
the rift. Therefore, the clockwise rotation model best described the opening history of the entire rift (Liu et al., 2019).

The southern segment of the rift has undergone the most extension with evidence showing parallel basins and ranges about 2.5 times wider than the northern segment of the rift. Earlier phases of rifting are characterized by weakly bi-modal, but mostly extrusive basaltic andesite, and the formation of NW-SE trending faults and basins (Morgan, 1986). The later phase of extension (latest Miocene-Pliocene) produced N-S, NW-SW and even E-W trending faults that bound the modern mountain blocks and basins (Morgan, 1986). Basin geometries consist of uplifted blocks that are structurally adjacent to down-dropped grabens or half-grabens. Although the structural grain of extension of the Rio Grande rift trends north, many fault segments show a different strike orientation. Fault strike in the southern rift ranges from N-S, to NW-SE to E-W.

Neogene and Quaternary faulting related to growth of the southern Rio Grande rift extends

from New Mexico through El Paso to Big Bend, Texas (Fig. 1). This segment has been affected by extensive Neogene and Quaternary faulting (Haenggi_2002). Haenggi (2002) suggests the region between el Paso and Big Bend is a continuation of a postulated intracontinental transform along the southern edge of the Colorado Plateau and has been the core of faulting related to right transtension over the past $24 \mathrm{Ma}$. It has been noted that any of the rift structures present in this region could have potentially been influenced by past structures such as the Chihuahua Trough since they occur along elements of pre - existing structural fabrics (Haenggi, 2002).

\section{Previous fault kinematic studies done in the Rio Grande rift}

\section{NORTH/CENTRAL RIFT}


Fault kinematic studies for the north - central Rio Grande rift have been used to investigate patterns of deformation from the Cretaceous to the present. Most paleostrain studies performed in this region have focused on the Tusas - Abiquiu segment of the north-central Rio Grande rift (e.g. Liu et al., 2019). They specifically assess the kinematics and pre-existing crustal weaknesses of the rift. Smaller scale studies within the Tusas - Abiquiu segment have focused on the Proterozoic and Paleozoic rocks flanking the Española Basin (e.g. Caine et al., 2017). Other fault kinematic studies in the central rift assessed strain transfer within basins in the central Rio Grande rift (Minor et al., 2013). Below I briefly summarize the main conclusions of several important fault kinematic studies from the central Rio Grande rift.

\section{Minor et al., 2013}

Results from paleostress studies performed by Minor (2013) in the central Rio Grande rift focused on understanding extensional strain adjacent to and within the Santo Domingo basin of northern New Mexico. The Santo Domingo basin structurally links the N-S trending Albuquerque and Española rift basins (Fig. 1). Minor (2013) found that the NE-SW trending segments of the Sant Domingo basin is dominated by NE- trending, normal oblique faults, rather than N-S normal faults. The NE-SW trending oblique faults preserve large arrays of strike and rake measurements. Cross-cutting relationships of fault planes and slickenlines within the Santo Domingo basin suggests that $\mathrm{E}-\mathrm{W}$ trending $\sigma_{3}$ stress was rotated to NW/N trends in the later stages of rifting and lasted until 2.7 - 1.1 Ma (Minor et al., 2013). Findings from the central rift propose that the clockwise rotation of $\sigma_{3}$ is consistent with increased bulk sinistral-normal oblique shear along the central Rio Grande rift segment. Regional geologic evidence suggests that in the late Miocene, the width of active faulting was confined to the Santo Domingo basin and along the axis of adjacent 
basins. Minor (2013) infers that the clockwise stress rotations developed mutually with the oblique rift segment, suggesting that the oblique segment of the central rift is a product of mechanical interactions of large faults propagating toward each other from adjoining basins as the rift narrowed.

\section{Caine et al., 2017}

The Española Basin is a result of multiple deformation events that happened in a progressive counterclockwise-rotating, far field reverse fault stress regime (Caine et al., 2017). This suggests that the Proterozoic and Paleozoic rift - flanking rocks have recorded incremental strains from early Laramide to late Tertiary. Field observations and cross - cutting relationships provide good constraints that suggest the maximum horizontal extension was dominantly $\mathrm{E}-\mathrm{W}$ during the late Tertiary. This indicates that normal faulting occurred after contractional and strike - slip faulting (Caine et al., 2017). Additionally, Caine (2017) suggests that the extensional slip reactivated major and minor structures that possibly formed during the Laramide Orogeny. The evidence includes closely located and similar orientation of reverse and strike - slip faults with major and minor normal faults and their related structures (Caine et al., 2017). Finally, few of the more outstanding NE - striking, steeply dipping faults in the Española Proterozoic flank, such as the Santa Fe fault, contain slickenlines and shear sense data that indicate sinistral strike - slip movement. Caine et al. (2017) propose that rift flank faults are "wrench" faults between the Picuris - Pecos and another northerly striking basement structures (Caine et al., 2017).

\section{Liu et al., 2019}

Fault kinematic data from the NW-trending Tusas - Abiquiu segment of the Rio Grande rift preserves almost pure dip slip faults and minor dextral oblique slip faults (Liu et al., 2019). These rift border faults accommodate SW, W, and NW oriented extension. Similarly, reactivated faults from the NE- trending Abiquiu segment also preserves mostly dip-slip faults as well as 
normal-sinistral and normal-dextral sense of shear. Faults within the rift are preserved within riftfilled sediments and preserve N, NE and NEE striking dip slip normal faults. Findings by Lui et al (2019) favor the multi-directional rotational extension model which hypothesizes a rotation from NE-SW to NW-SE directed extension between 29-26 Ma. Finally, Liu et al (2019) further support that the landscape evolution and deposition in the early phases of rift opening may be attributed to tectonic reactivation.

\section{SOUTHERN RIFT}

\section{Carciumaru and Ortega, 2017}

Existing fault kinematic data from the southern region of the rift is restricted to the Franklin and East Potrillo Mountains (Scharman, 2006; Carciumaru and Ortega, 2017). Data collected from the Franklin Mountains and East Potrillo Mountains focused on low-angle normal faults. Their results indicate that these faults preserve a polyphase deformation history and that deformation cannot be attributed to one single continuous event. The fault kinematics and geometry imply that the formation of low-angle normal faults is consistent with two phases of extension. The first phase showed a $\mathrm{N}-\mathrm{NE}$ extension direction followed by a second phase that involved $\mathrm{E}-\mathrm{W}$ extension (Carciumaru and Ortega, 2017).

The oldest fault population in the East Potrillo Mountains formed during N - NE horizontal extension. This fault population is hypothesized to have formed during N-NE horizontal extension in the early Miocene (Carciumaru and Ortega, 2017) due to consistency with previously calculated directions of extension (Mack et al., 1994). It has been demonstrated, using kinematics data and fault slip analyses, that this fault population was formed in a different stress field than previously thought. The second fault population in the Potrillo Mountains records East - West extension with 
moderate southeast plunge. Even though the extension direction correlates with the one recorded at the Franklin Mountains, the shortening direction does not. A probable explanation is that the orientation of the present-day faults is controlled by the orientation of pre-existing low-angle normal faults. Hence, this fault set may be a product of the same deformation events recorded in faults from the Franklin Mountains or the faults may have formed during an intermediate stage of extension. If it is attributed to an intermediate stage of extension, this stage would be highly transtensional due to the oblique nature of the slickenlines. A flaw in this hypothesis is that similar faults have not been found throughout the region. For this reason, the reactivation hypothesis is favored (Carciumaru and Ortega, 2017).

\section{Common models proposed to explain changes in fault strike through the Rio Grande rift}

\section{FAR-FIELD STRESS ROTATION MODEL}

During the late Cretaceous - Early Tertiary the western boundary of the United States underwent Laramide "flat slab" subduction which produced compression-oriented NE-SW and E-W. The period between 40-20 Ma is characterized by the transition from "flat slab" subduction to "steep slab" subduction and ultimate foundering of the Farallon slab. Eaton (1979b) suggests that this transition resulted in a change from compressional to extensional stresses.

The Rio Grande rift is hypothesized to have developed in two phases of extension (Morgan, 1986). The two-phase extension hypothesis is consistent with the contemporary regional stress field associated with the Basin and Range province (Zoback, 1980). The early phase began in the midOligocene (about $30 \mathrm{Ma}$ ) and continued until the Early Miocene (18 Ma) and is temporarily and spatially association with major magmatism. The trend of late Oligocene to middle Miocene faults, basins, and dikes were used to calculate the orientation of the regional stress field (Morgan, 1986). 
It has been observed that the most common trend of structures is between N-S and NW-SE $\left(\mathrm{N} 60^{\circ} \mathrm{W}\right)$, averaging $\mathrm{N} 30^{\circ}-40^{\circ} \mathrm{W}$. The trend of major structures plus low-angle faults, relatively broad, shallow basins are all characteristic of the first phase of extension and indicate approximately NE-SW extension. This early phase is possibly closely related, if not an extension to the broader Basin and Range extension where early extension is suggested to also be NE-SW oriented (Zoback, 1980). Although the cause of the stress field rotation is widely debated, a common observation is that the transition from early to late phase extension occurred across the span of the middle Miocene magma gap (Morgan, 1986). This could possibly indicate that the rotation of stresses is thoroughly related to change in the style of volcanism and may even be related to activity in the upper mantle (Morgan, 1986). The later phase of extension mostly occurred in the late Miocene (10-5 Ma) and is ongoing until the present day. Fault-related horsts and grabens trend N-, although many fault segments trend NW-SE or even E-W. Because the structural trend is N-S, this results in a structural truncation of older tectonic trends. The trend of: high-angle faults, graben/half-graben basins and tilted fault blocks suggest that these major structures were produced during second phase, E-W extension.

To summarize, the "far-field stress rotation model" is based on strike trends of faults, basins, dikes, horsts and grabens in the southern Rio Grande rift. It calculates a stress field based on the presentday orientation of structures. Furthermore, results are correlated with contemporary regional stress field models associated with the Basin and Range province (Zoback, 1980).

\section{FAUlt REACTIVATION MODEL}

The hypothesis of reactivation along the Rio Grande rift has been previously proposed and documented (Mack, 2004). Isolated cases of reactivated faults throughout the rift may indicate that 
extension in the southern rift was influenced by the structural grain of underlying bedrock. For example, Morgan (1986) suggests that the change in fault strike cannot be explained by different phases of extension of the Rio Grande rift but rather as a product of E-W extension acting upon older structures. In addition, basin boundary faults that formed during the opening of the Chihuahua Trough were later re-activated during compression of the Laramide orogeny to highangle reverse faults, with a left lateral component of motion (Haenggi, 2002). Another example is from the region near the Emory cauldron, which records multiple reactivated faults (Jones et al., 1967). Faults near the ring-fractures are re-activated Laramide structures that were once again reactivated during extension of the Rio Grande rift, long after the extinction of the cauldron. A final example is the strike-slip Picuris-Pecos fault located in the Sangre de Cristo Mountains (Baur and Ralser, 1995). Parts of the Picuris-Pecos fault are Paleozoic structures that were reactivated during the Laramide and again during Neogene rifting. Field data indicate that the Picuris-Pecos fault and adjacent sub-parallel structures produce a Laramide-age positive flower structure. These examples, coupled with the protracted tectonic history of the southern rift since the Proterozoic, highlight the potential that many faults in the southern Rio Grande rift may have also reactivated older structures. 


\section{METHODS}

In order to analyze faults that were active during extension of the Rio Grande rift, it is necessary to constrain the age of each fault. The principle of cross-cutting relationships establishes that a fault must be younger than the rocks it cuts through. While absolute ages of faults are typically unknown, for this study I focused on faults that cut units that are younger than $40 \mathrm{Ma}$ (termination of the Laramide Orogeny).

The methods to conduct a paleostrain analysis can be divided into two categories: field and computational methods. This is in order to statistically interpret the "minimum stretching

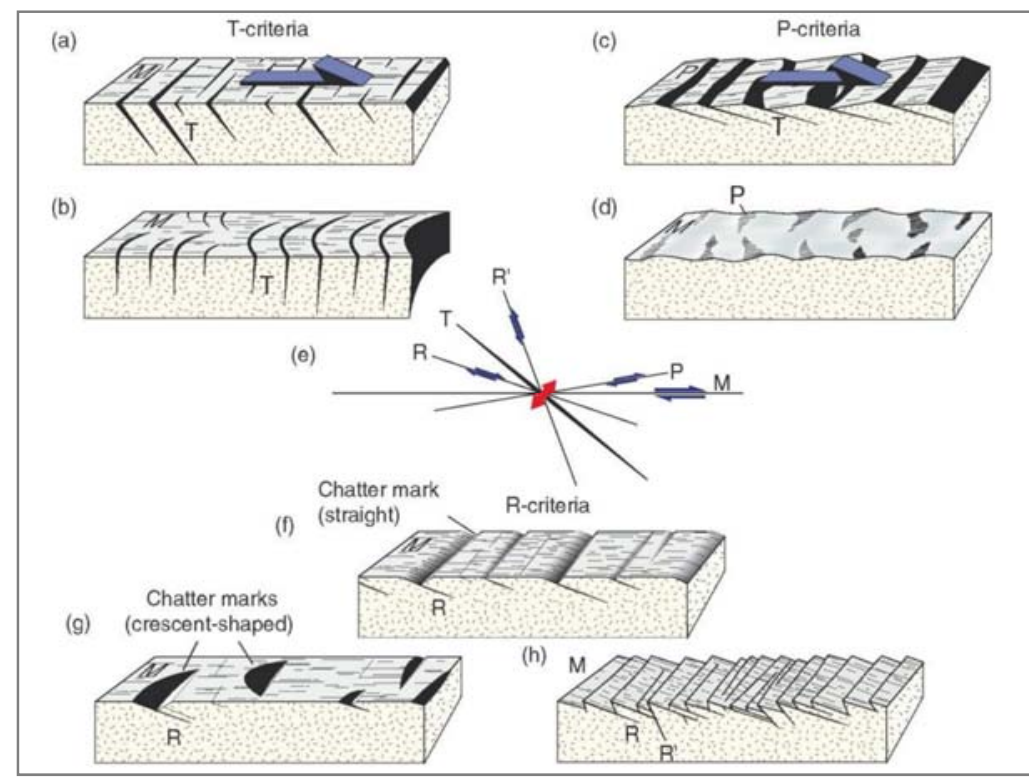

Fig. 3 Diagram illustrating different shear sense indicators that can be identified off of fault planes.

Source: Structural Geology, Fossen, 2016 direction" $\left(\mathrm{S}_{1}\right)$ and the "maximum shortening direction" $\left(\mathrm{S}_{3}\right)$. Field methods consist of measuring and classifying fault slip surfaces (Burg, 2017). For each slip surface, measurements and observations involve: (1) strike and dip of fault slip plane; (2) a rake value for each set of slickenlines; and (3) a slip - sense determination with a certainty

ranking for each set of slickenlines. Fault zones may produce a system of shears that may serve as indicators of the orientation of the fault zone boundary, therefore allowing for the shear sense to be determined. Brittle shear sense indicators may include Reidel shears, chatter marks, and enechelon veins, among others (Fig. 3). For slip surfaces that expose multiple sets of slickenlines, 
the relative timing of each set should be assessed with the use of a hand loupe, cross-cutting relationships and a favorable sun angle (Minor et al., 2013).

In order to understand the computational methodology, it is necessary to describe key terms and principles. The "Kinematic Axes" represent the orientations of the minimum and maximum shortening $\left(\mathrm{S}_{1}\right.$ and $\left.\mathrm{S}_{3}\right)$ directions and their relative magnitude (shape of strain ellipsoid). The paleostrain method assumes that the studied faults formed during the same deformational event, the rocks are

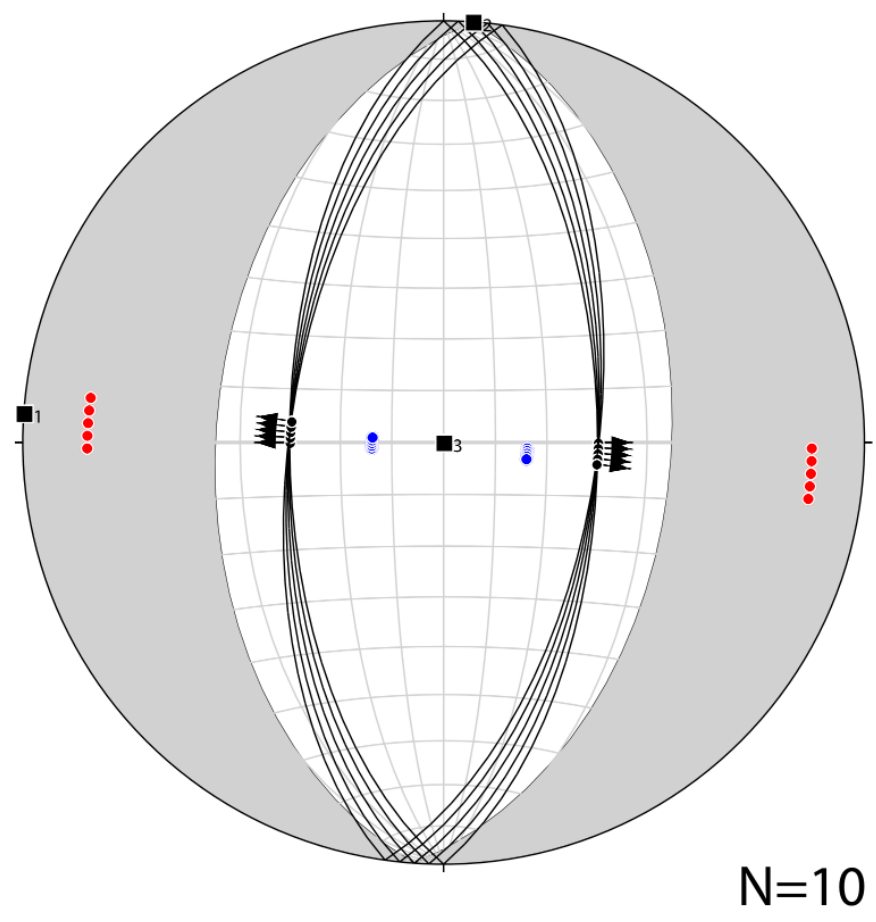
homogenous, strain remained relatively low and that the structures have not rotated significantly (Fossen, 2016).

Measurements and observations were plotted on stereonets using FaultKin v. 7.5 (Fig. 4) (Marrett and Allmendinger, 1990). Fault sets with 5 or less measurements were not considered to

Fig. 4 Lower hemisphere stereonet using hypothetical measurements to illustrate the different components of the study's results.

All data- all fault measurements collected

Population 1-average - the P \& T axes fall within the best fit conjugate fields (fault plane solution).

Population 2 - outlier - the P \& T axes do not fall within the best fit conjugate fields (fault plane solution).

Misfits - additional faults measurements that do not fit any of the deconvolutions nor makes geologic sense

produce reliable results. Kinematic axes were plotted for each fault plane measurement. For each fault plane and slip vector measurement, a "movement plane" is calculated. The movement plane is defined as "the plane that contains the slip vector and pole to the fault." The P- (shortening) and 
$\mathrm{T}$ - (extension) axes each plot $45^{\circ}$ from the pole to the fault plane and within the movement plane, where the sense of slip is used to distinguish between the two kinematic axes. Individual P- and T-axes can be plotted for each fault plane and slickenline measurements (Plot $>$ Scatter $>$ Both P \& $\mathrm{T})(\mathrm{Ctrl}+\mathrm{L})$, and the results contoured by density (Plot $>$ Scatter $>$ Both) $(\mathrm{Ctrl}+\mathrm{K})$, (Marrett and Allmendinger, 1990).

Once the kinematic axes for each fault set are plotted, the following process can be applied in order to compare if fault sets are kinematically compatible to one another. After the collected fault data (strike, dip, rake and shear sense) is input into FaultKin all fault data are plotted on stereonets (Plot $>$ Faults $>$ Plot All) $(\mathrm{Ctrl}+\mathrm{G})$ (Fig. 4). Once the faults are categorized based on fault type, the Kinematic Axes are calculated using Bingham statistics (Plot $>$ Kinematic Axes $>$ Linked Bingham) $(\mathrm{Ctrl}+\mathrm{B})$. For each fault type grouping, all individual $\mathrm{P}-\mathrm{T}$ axes were superimposed on a fault plane solution (Plot $>$ Fault Plane Solution $>$ From Linked Bingham) (Ctrl + Y) (Fig. 4). This fault plane solution represents the average or best-fit conjugate fields for $\mathrm{P}-\mathrm{T}$, based on the Bingham statistics for the fault set. For the fault plane solution, the gray area represents contraction and the white represent tension. Individual faults, whose $\mathrm{P}-\mathrm{T}$ axes do not fall within the best fit conjugate fields, are hand-picked and removed until only the faults whose P-T axis (from fault data) match the contraction / tension zones (from fault plane solution). If both the $\mathrm{P}$ and $\mathrm{T}$ axes plot on one single zone (either contraction or tension), they are not considered outliers. The misfit faults are re-tested using the linked Bingham method to evaluate their kinematic compatibility. The results can either indicate that the misfits pertain to a different set of faults or a combination of faults that might require future simplification of data. If after simplification, the misfit data does not fit any of the deconvolutions nor makes geologic sense, the faults are considered outliers. The measured orientations of the $\mathrm{P}-\mathrm{T}$ axes and $\mathrm{P}-\mathrm{T}$ fields are then 
compared among all the other calculated fault sets for the purpose of determining similarity between them and later on, compare them to previously estimated regional strain fields. This unweighted approach solely relies on the geometry of the studied faults and provides a consistent foundation for comparison (Caine et al., 2017).

In addition to the paleostrain analysis, Geographic Information System (GIS) software were used to analyze and present data. GIS is a computational mapping system used for analyzing data on the Earth, according to the geographic location (Clarke, 1999). The map figures used for this project were created and compiled using ArcMap. Paper maps were scanned as TIFF format images, georeferenced using ground control points and digitized, in order to present the region of interest and its geologic features. 


\section{STUDY AREA}

The study area for this project is in southern New Mexico and western Texas (Fig. 5). In southern New Mexico, fault kinematic data were collected from four mountains ranges: Black Range, Hillsboro, Cookes Range, and the Robledo Mountains. In western Texas, data were collected from two ranges: The Franklin Mountains and the Indio Mountains. All six ranges had exposures of rift-related faults. To find these locations, geologic maps were used to locate NWtrending normal faults that cut rift-related geologic units. Furthermore, additional Bureau of Land Management (BLM) maps were also consulted to determine whether the ranges were accessible to the public. 


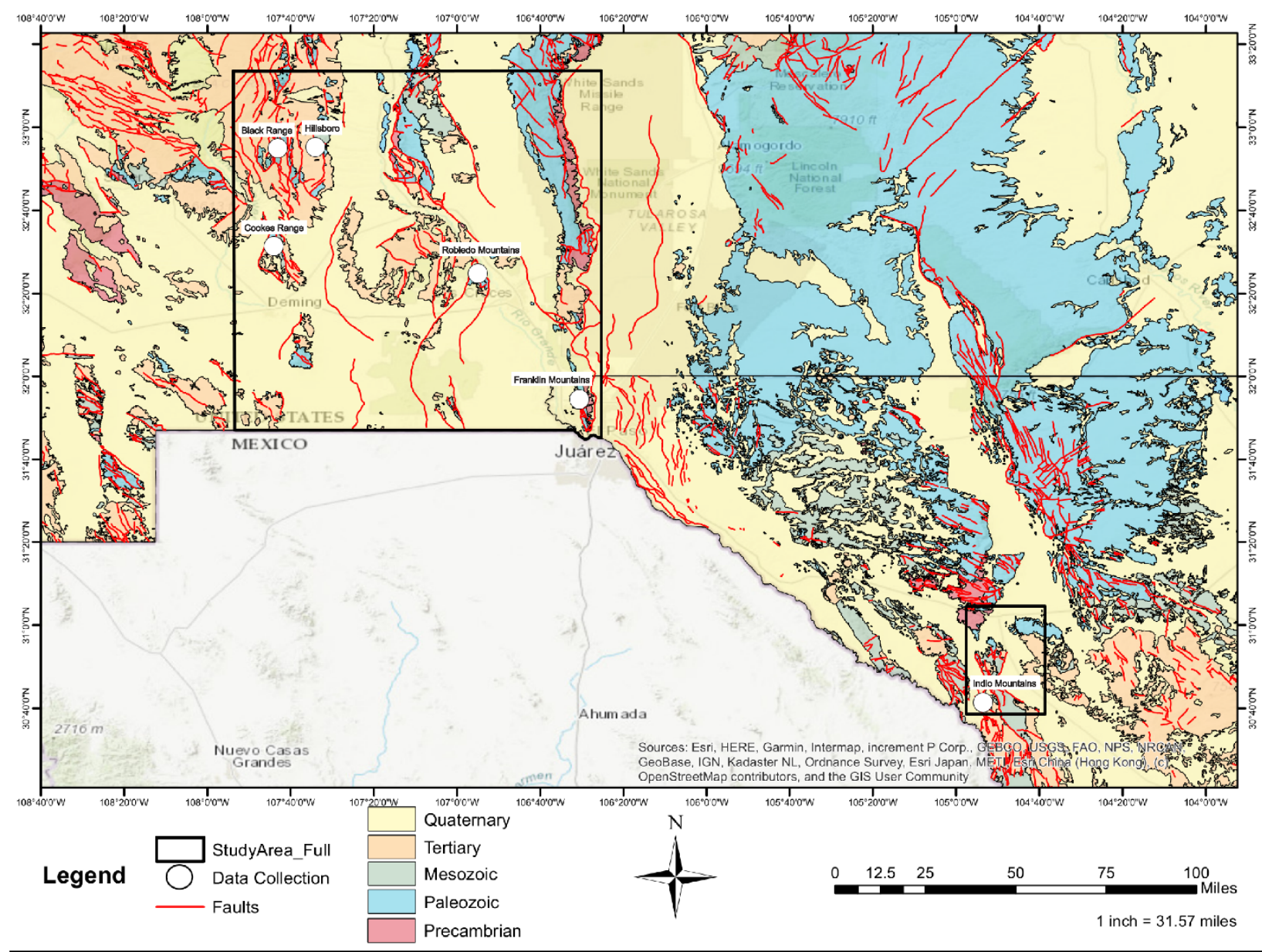

Fig. 5 Geologic map of the southern Rio Grande rift region. The two study areas are marked by the black rectangles and the six ranges are labeled by name. 


\section{RESULTS}

The measurements collected throughout six mountain ranges are plotted on lower hemisphere stereonets. In the following figures, the stereonet located on top contains all the data collected for the mentioned range. Measurements labeled "population 1" indicate that the P \& T axes fall within the best fit conjugate fields (fault plane solution). Measurements labeled "population two" indicate that the P \& T axes do not fall within the best fit conjugate fields-

outliers. For certain ranges, additional faults measurements that do not fit any of the deconvolutions nor makes geologic sense are labeled "misfits". For specific fault measurements and locations, refer to the appendix.

\section{Cookes Range}

The stratigraphic section of the Cookes range is nearly complete, including rocks ranging from Proterozoic basement to late Cenozoic in age (Jicha, 1954). At least 650 m.y. of rock record is missing across the Great Unconformity between Proterozoic basement and Cambrian sandstone. During the Early Mesozoic, the Cookes range was a highland on the flank of a Jurassic rift basin. Early Mesozoic rocks are also missing from the rock record; likely because they were never deposited or were eroded (Lawton, 2000).

During compression of the Laramide orogeny, a NW-trending basin formed in the southern Cookes range, preserving Paleocene to Eocene conglomerate, sandstones and mudstones (Clemons and Mack, 1988). The conglomerates preserved in the basin were derived from the Laramide-age Burro uplift. Eocene intrusives were associated with early volcanic activity in the Mogollon-Datil volcanic field (MDVF). Later, regionally extensive ash flow tuffs have been sourced to eruption of calderas in the MDVF. Early phases of extension began to uplift the Cookes block, which is 
bounded on three sides by normal faults and tilted south. This tilting exposes older rocks in the northern section of the range.

Data were collected from three normal faults with an age younger than $\sim 38 \mathrm{Ma}$. The age of the faults is constrained using cross-cutting relations because all three faults offset Eocene and/or Oligocene rocks. Relative age constraints of the faults were approximated using crosscutting relationships. Fault A places Eocene Rubio Peak on the hanging wall against Cretaceous Sarten sandstone in the footwall. For fault B, the hanging wall preserved Rubio Peak and the hanging wall was Oligocene Granodiorite. For Fault C, the hanging wall showed Eocene Rubio Peak and the footwall was Cretaceous Sarten sandstone. 
Fault data from the Cookes range show fault plane orientations (fault strike) that range from N-S to NW-SE and slickenline orientations that range from dip slip to strike slip (Fig. 6). The overall direction of extension for all faults collected in the Cookes range is E-W. Although there is a change in both fault strike and slickenline orientation; the results suggest that E-W extension remains constant. A kinematic compatibility analysis calculates the T-axis (tension) trends 092 degrees towards 006 degrees, and it suggests E-W extension. The P-axis (contraction) trends 307.2 degrees towards 82.8 degrees, and it suggests vertical shortening. The outlying fault measurements were further analyzed $(\mathrm{n}=90)$ and the $\mathrm{T}$-axis remained $\mathrm{E}-\mathrm{W}$.

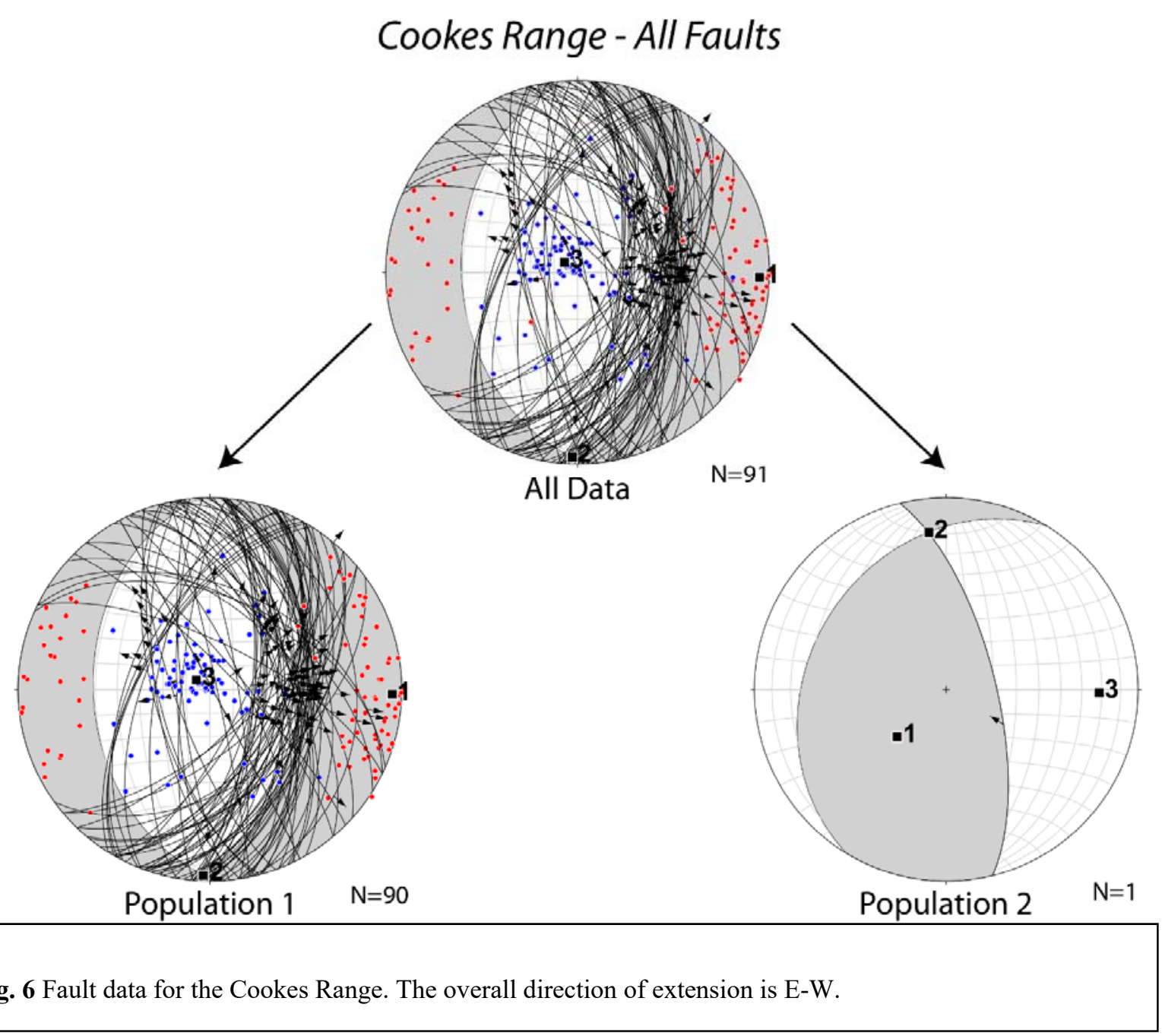




\section{Black Range}

The Black Range (Fig. 5) has small exposures of Precambrian age rocks. Overlying the Precambrian rock, Paleozoic strata were deposited in a continuous sequence from the Cambrian(?) to Permian periods (Clemons, 1982). Tertiary rocks in the Black Range can be divided into three groups. From oldest to youngest: 1) andesitic and latitic rocks, 2) rhyolitic intrusives and extrusives and 3) andesitic volcanic rocks. The older andesitic and latitic rocks have been altered on a regional scale, whereas the younger rocks have not (Kuellmer_1954). The region near Emory cauldron, in the Black Range, records multiple tectonic events and cross-cutting relationships between geologic structures is difficult to distinguish. Reactivation of faults is common in this region (Elston_1975).

Data were collected from four faults in the Black Range. The four faults cut rhyolitic ashflow tuffs, which are lower Oligocene to upper Eocene (31-36 Ma) in age. All the faults expose rhyolitic ash-flow tuff in both hanging wall and footwall, except for fault A which exposes Paleozoic Abo Formation in the footwall.

Results from the Black Range show a wide range in fault strike orientation (Fig. 8). Most faults have dip-slip slickenlines, although some were oblique slip. Some of the observed faults in the Black range preserve cross-cutting relationships between oblique slickenlines, suggesting the possibility that these faults may have experienced multiple deformation events (Fig. 7). The kinematic T-axis for all the faults in the Black Range is mostly E-W and the P-axis is

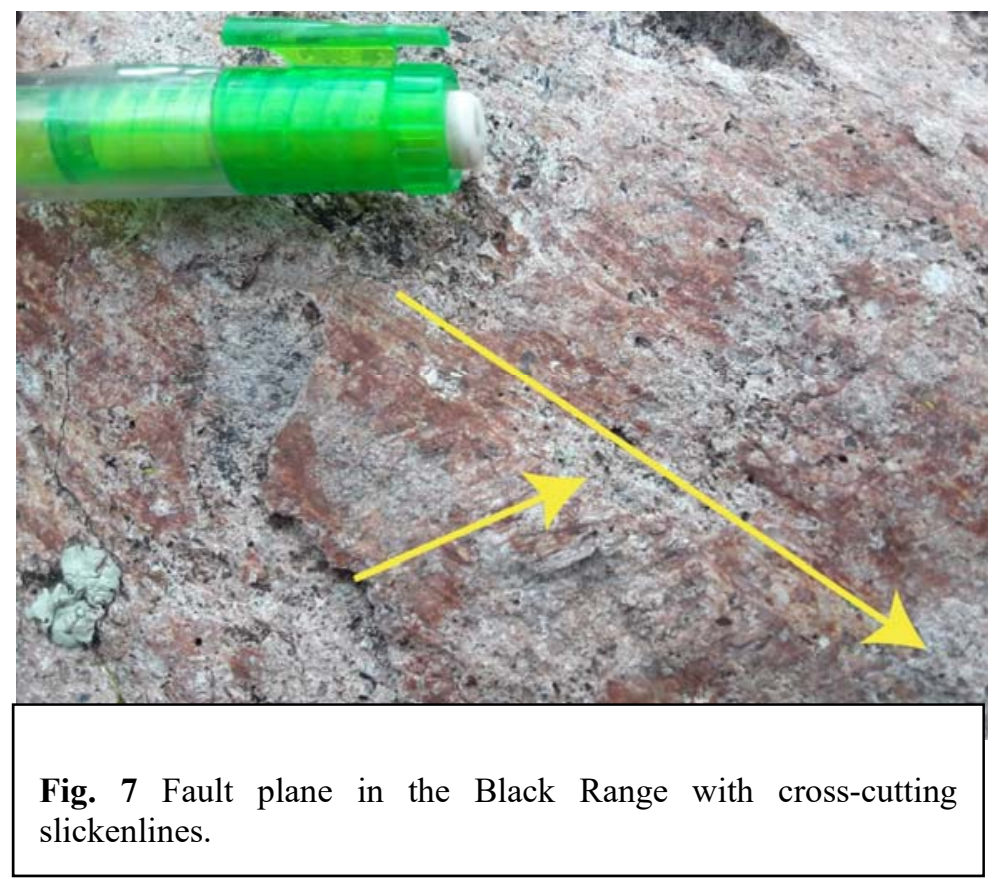


approximately vertical. Compatible faults in population 1 were further analyzed, the calculated Taxis $(n=34)$ plunges 284 degrees towards 005 degrees, and the P-axis is approximately vertical. Incompatible faults in population $2(\mathrm{n}=9)$ suggest a calculated T-axis oriented N-S with some vertical component and the P-axis is oriented E-W. Finally, a second compatibility analysis was performed on a single outlying fault, but due to the low number of measurements the results are considered unreliable.

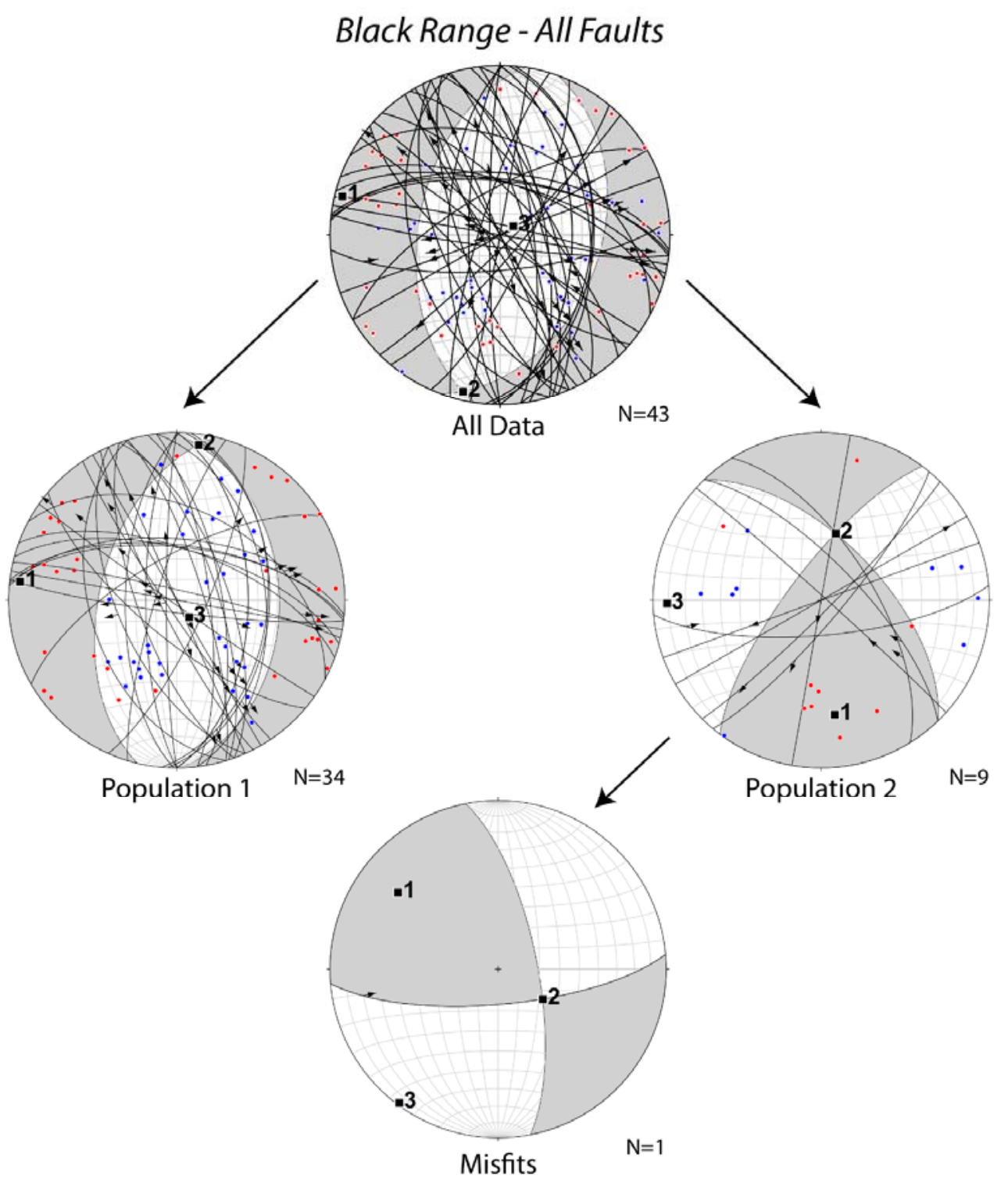

Fig. 8 Fault data for the Black Range. The overall direction of extension is E-W. Fault population 2 suggests N$\mathrm{S}$ extension and E-W contraction. 


\section{Hillsboro}

Exposures of Proterozoic rocks are present in the northern section of the Hillsboro caldera. The Paleozoic stratigraphic section is complete from the Cambrian to Permian (Kelley et al., 2014). The collapsed caldera preserves mostly late Cretaceous volcanic and intrusive rocks. Tertiary and volcanoclastic units are preserved mostly surrounding the caldera. Finally, Tertiary - Quaternary basin fill units were deposited. The Cretaceous caldera preserves many dikes that radiate outward from the center. Normal faults in the region range from NW-SE to N-S trending. These faults mostly cut through younger Tertiary and Quaternary units, although some of them displace Cretaceous units as well. Cross-cutting relationships indicate that these normal faults formed between $\sim 35$ and $1 \mathrm{Ma}$, most likely related to the opening of the Rio Grande rift.

Fault kinematic data from Hillsboro were collected from normal faults that contain Tertiary Santa Fe Group deposits in the hanging wall and mainly Ordovician El Paso Group in the footwall. Other footwall units included Cretaceous andesite flows and Quaternary colluvium.

The collected data show a large range of fault plane orientation with predominantly oblique slip to almost strike-slip slickenlines (Fig. 9). The T-axis plunges 282 degrees towards 015 degrees and the P-axis plunges 169 degrees towards 055 degrees. Once the incompatible fault measurements were analyzed, population $1(\mathrm{n}=17)$ still shows $\mathrm{E}-\mathrm{W}$ extension and population 2 $(\mathrm{n}=3)$ indicates that the $\mathrm{T}$-axis plots is $\mathrm{N}-\mathrm{S}$ and the P-axis E-W. 


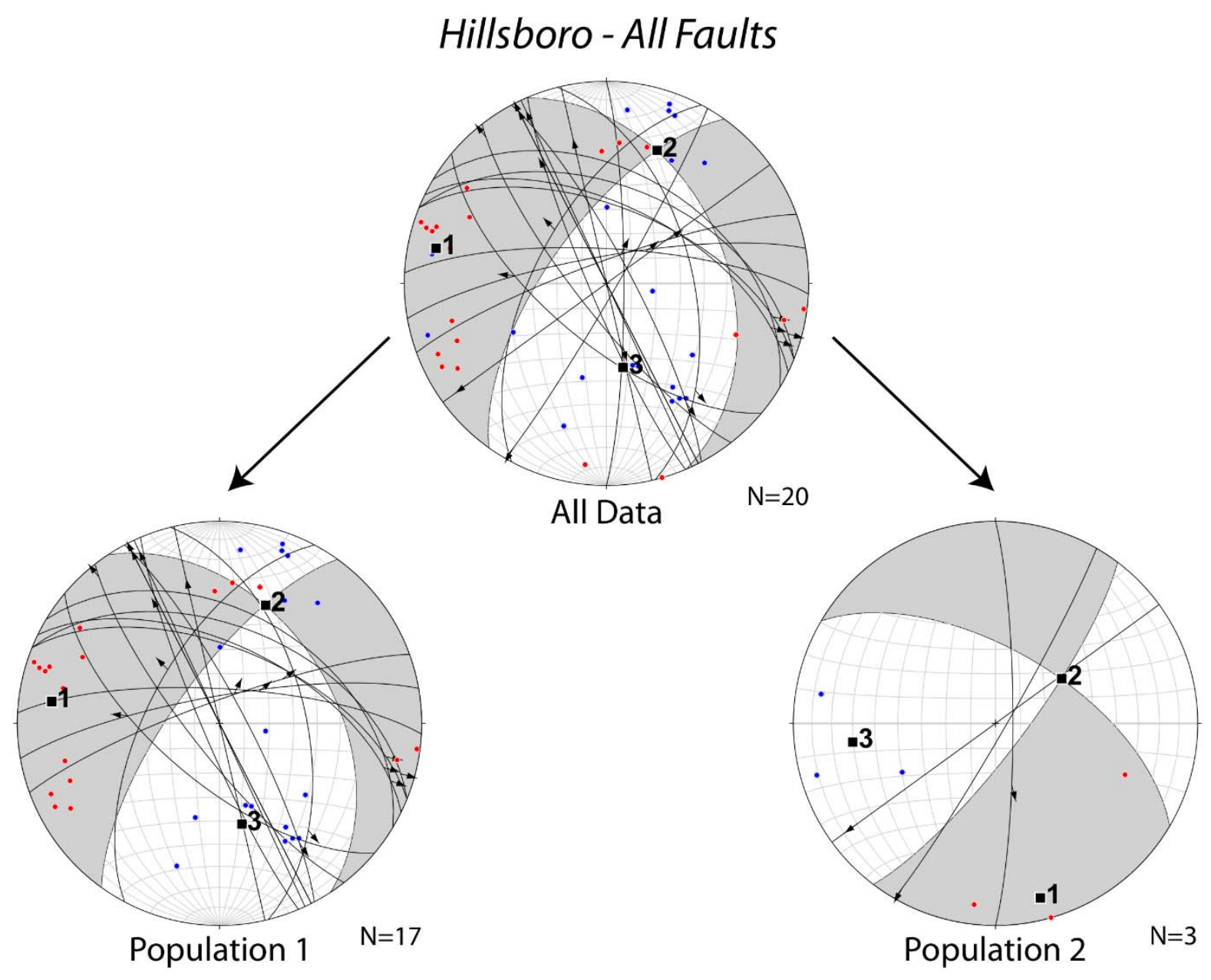

Fig. 9 Fault data for the Hillsboro Mountains. The overall direction of extension is E-W.

\section{Robledo Mountains}

Paleozoic rocks make up the bulk of the bedrock of the Robledo Mountains (King and Haley, 1975). Mostly complete stratigraphic sections from the Cambrian-Ordovician to Permian are exposed along the eastern and western edges of the uplift. The uplift is bounded on both sides by $\mathrm{N}-\mathrm{S}$ trending conjugate normal faults, and the range formed during extension of the Rio Grande rift. Kinematic data were collected from the northwest end of the Robledo Mountains in the lower Tertiary sedimentary rocks which consist of Palm Park volcaniclastic facies and Rincon Valley 
fanglomerates (interbedded conglomeratic sandstone, sandstone and mudstone) (King and Haley, 1975). These units crop out along the flanks of the range.

Stereonet plots for fault data collected from the Robledo Mountains show a very wide range of fault strike orientations, although slickenlines show predominantly dip-slip normal faults (Fig. 10). The fault measurements collected from the Robledo Mountains $(n=114)$ suggest that the Taxis plunges 171 degrees towards 009 degrees and the P-axis is approximately vertically. The compatible population 1 fault measurements $(\mathrm{n}=77)$ were further analyzed and the calculated $\mathrm{T}$ axis is N-S and P-axis is vertical. Furthermore, another fault plane solution was plotted for fault population $2(\mathrm{n}=37)$ that shows an $\mathrm{E}-\mathrm{W}$ extension direction.

\section{Robledo Mountains - All Faults}

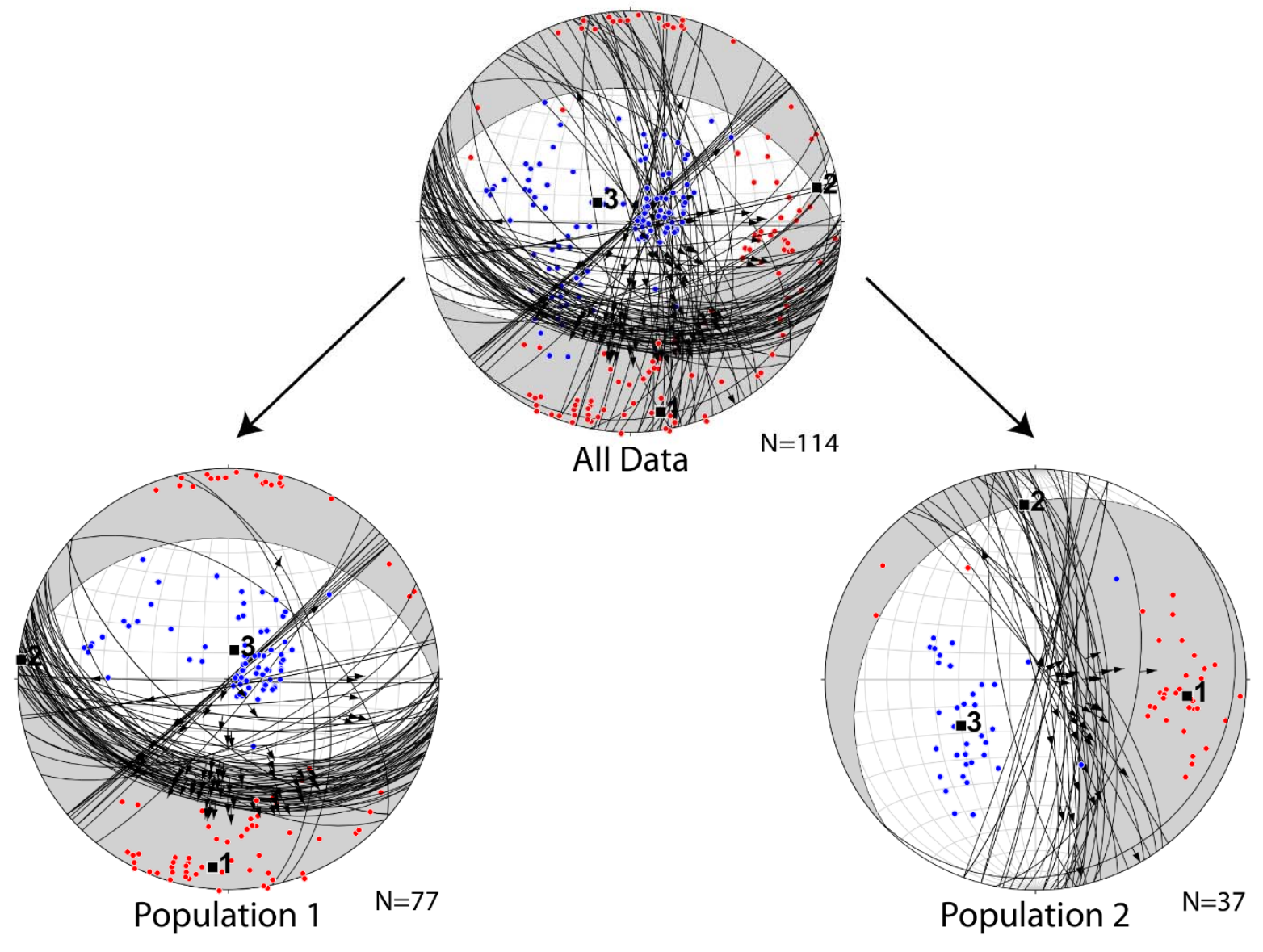

Fig. 10 Fault data for the Robledo Mountains. The overall direction of extension is N-S although fault population 2 shows mostly E-W extension. 


\section{Franklin Mountains}

Rocks in the Franklin Mountains range from Proterozoic to Holocene in age. A near-complete stratigraphic column is preserved except the Triassic and Jurassic, which do not crop out throughout the range (Harbour, 1972). Proterozoic rocks consist of plutonic, volcanic and sedimentary rocks that are unconformably overlain by a complete Paleozoic section. Paleozoic rocks were deposited during episodes of regression and transgression of a shallow sea, preserving many marine fossils. During the Mesozoic, little deposition occurred until the Cretaceous period when shallow marine sediments were deposited (Lucas et al., 1998). At the beginning of the Cenozoic $(66 \mathrm{Ma})$ the Laramide Orogeny caused both brittle and ductile deformation in the western United States (Carciumaru and Ortega, 2008). It is still debated whether initial uplift of the Franklin Mountains occurred during the early Cenozoic (due to compression) or mid-Cenozoic (due to extension). During the mid-Cenozoic ( $\sim 35 \mathrm{Ma})$, extension of the Rio Grande rift tilted and uplifted the Franklin Mountains block (Chapin, 1979) while producing surrounding basins such as the Hueco Bolson to the east and the Mesilla Basin to the west. Evidence for tilting during extension of the rift is based on cross-cutting relationships of the East Franklin Mountain fault. Studies performed on this fault found fault scarps that displace Quaternary deposits (Keaton and Barnes., 1996; Raney and Collins, 1990; Lovejoy, 1976). The basins surrounding the Franklin Mountains not only preserve sediment sourced from the range but also sediment that was carried by the ancestral Rio Grande river (e.g. Armour et al., 2018).

For the purpose of this project, fault kinematic data were collected from two different sets of faults which had different orientations than the main East Franklin Mountain fault, which trends $\mathrm{N}-\mathrm{S}$ along the eastern edge of the range. Knowing that the faults had been tilted by the Eastern Franklin fault the data were rotated. The azimuth of rotation axis was set at $0^{\circ}$, the plunge of 
rotation axis at $0^{\circ}$ and the magnitude of rotation at $30^{\circ}$. The data $(n=9)$ plot as NW-SE and NESW trending oblique-slip faults that yield a T-axis oriented NW-SE trending 144 degrees towards 00.3 degrees and a P-axis oriented NE-SW trending 234 degrees towards 40 degrees (Fig. 11). There were no misfit data for this mountain range, indicating that the different fault sets for the 1Franklin Mountains are kinematically compatible.

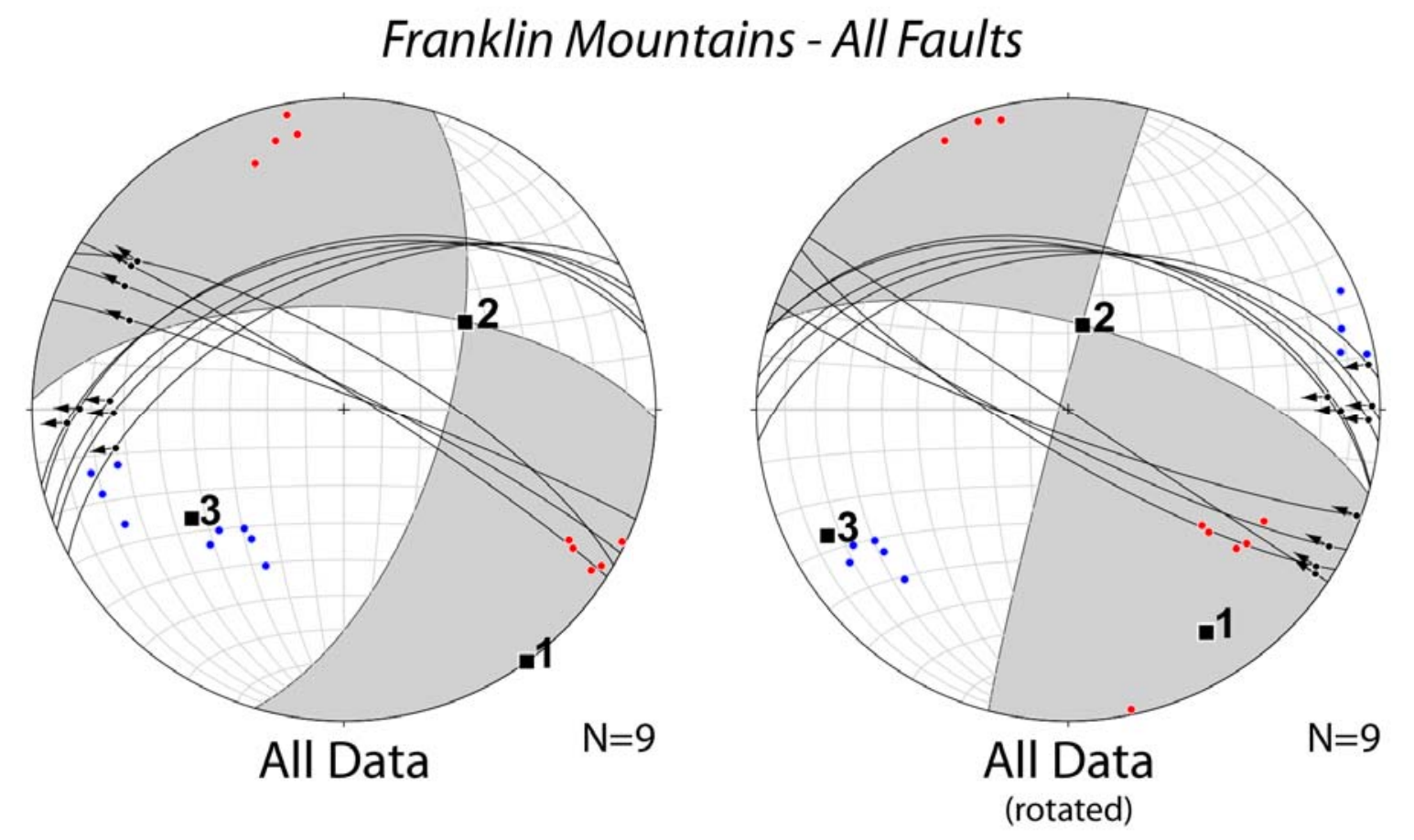

Fig. 11 Fault data for the Franklin Mountains. The overall direction of extension is SE-NW. The data on the "rotated" stereonets still suggests SE-NW extension.

\section{Indio Mountains}

The Indio Mountains in western Texas and are mostly composed of sedimentary rocks (Underwood, 1962). Rocks ranging from the Ordovician - Pennsylvanian are missing in the section, possibly due to erosion (Underwood, 1962). Transgression of the Permian sea is recorded as alternating siliciclastic and carbonate rocks (Hills, 1972) that were deposited at the western margin of the Diablo platform the adjacent Chihuahua Trough. Most structural features are a 
product of compression during the Laramide orogeny (Underwood, 1962). Sediments from the Chihuahua Trough were asymmetrically folded and thrust towards the northeast (Underwood, 1962; De Sitter., 1956). Mid-Tertiary volcanism consisted of widespread ash flows and pyroclastic flows (Price and Henry, 1984). Regional uplift continued during the formation of the Rio Grande rift which created the currently horst and graben geometry present on the Indio Mountains (Seager and Morgan, 1979).

\section{Indio Mountains - All Faults}

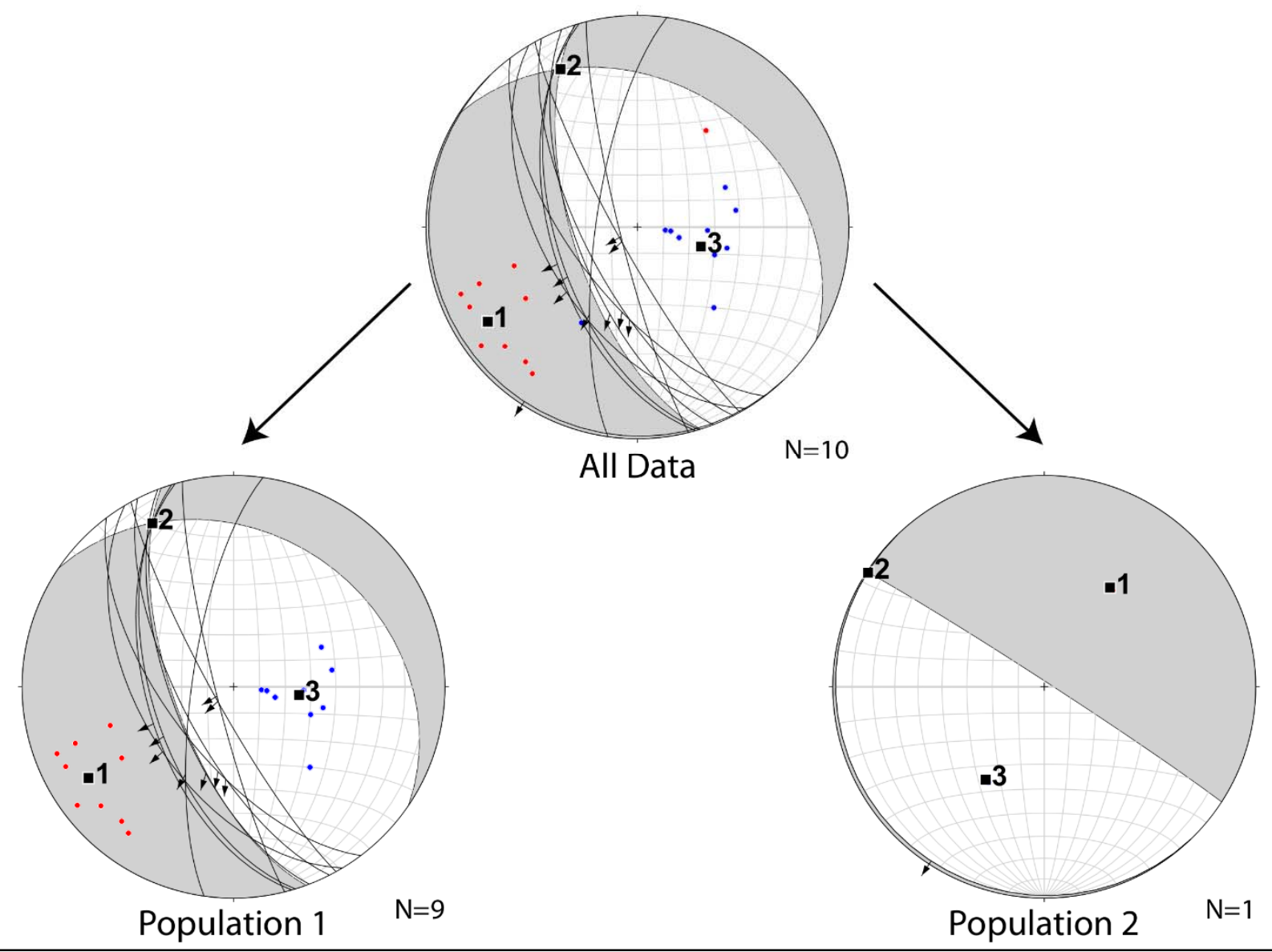

Fig. 12 Fault data for the Franklin Mountains. The overall direction of extension is SE-NW. The data on the "rotated" stereonets still suggests SE-NW extension.

Kinematic data were collected from a NW-trending normal fault in the Indio Mountains.

Once the data were plotted, the T-axis plunges 238 degrees towards 17 degrees and the $\mathrm{P}$-axis is approximately vertical (Fig. 12). Compatible population 1 measurements $(\mathrm{n}=9)$ show a $\mathrm{T}$-axis that 
plunges 238 degrees towards 20 degrees and a $\mathrm{P}$-axis that is almost vertical. For incompatible population 2 , there was one single measurement, but due to the low number of measurements the results are considered unreliable. 


\section{DISCUSSION}

\section{Investigating the possibility of fault reactivation}

Kinematic analysis from the southern Rio Grande rift suggests predominantly E-W extension for the majority of faults investigated. This is supported by faults with a wide range of fault strike and slickenline orientations (Figs. 6-12). Field observations and cross - cutting relationships in the northern/central rift suggest that maximum horizontal extension was dominantly E - W during the late Tertiary (Caine et al., 2017). Furthermore, cross-cutting relationships of fault planes and slickenlines within the Santo Domingo basin (central rift) also suggest Tertiary E - W trending extension until rotation to NW/N during the later stages of rifting (Minor et al., 2013). The results from this in the southern segment of the Rio Grande rift are similar to results from the central rift in northern New Mexico, supporting a regional geological model where the entire Rio Grande rift formed under regional E-W extension. If such a model were accurate, then this would imply that the southern segment of the rift may have re-activated older, underlying structures. This would help explain the change from N-S trending basins that extend from central Colorado to southern New Mexico to NW-SE trending basins, causing a geometric "bend" of the rift at the latitude of southern New Mexico. Faults were further analyzed by ranges to test for kinematic compatibility among faults sets.

The results indicate that several ranges could preserve evidence for fault reactivation. Besides cross-cutting slickenlines recorded in the Black Range, there are other ranges that may record reactivation. The Black Range (population 2) (Fig. 8), the Hillsboro Mountains (population

2) (Fig. 9) and the Robledo Mountains (population 1) (Fig. 10) all preserve fault populations with S1 plotting in the south and S3 to the east. The orientation of the kinematic axes cannot be correlated to extension of the Rio Grande rift. A model that could help explain this could be that 
these faults preserve older stresses- possibly related to the Texas Lineament. Using purely fault kinematic data, the Texas lineament is characterized by NW-SE trending pure strike-slip faults (left or right lateral is still debated). The calculated S1 plots in the north/south and S3 plots to the east.

COMPARING KINEMATIC DATA FROM THE SOUTHERN AND NORTHERN/CENTRAL RIO GRANDE RIFT

In order to more carefully document similarities and differences between fault kinematic data from the southern and central segments of the rift, all available fault measurements were compiled from studies conducted in the central rift (Minor et al., 2013; Caine et al., 2017; Liu et al., 2019). In this section, the two datasets (including 323 measurements from the southern rift and 1,621 measurements from the central rift) are compared using scatter plots and histograms.

\section{EXPECTED FAULT STRIKE AND RAKE ORIENTATIONS FOR THE RIFT}

The expected orientation of fault planes and slickenlines for the northern segment of the rift can be represented using simple $\mathrm{X}$ and $\mathrm{Y}$ plots. Figure 13A is a hypothetical plot of fault strike vs. rake using right-hand rule convention. The northern Rio Grande rift is dominated by N-S trending faults, where faults should ideally have strike values of $0^{\circ} / 360^{\circ}$ and $180^{\circ}$. This population of faults is represented by the vertical red bars. In addition, if they are pure normal faults, which would be expected if they formed under region EW extension, then they should have a rake value of $90^{\circ}$. This value is represented by the horizontal bar. Fault kinematic data collected from the northern and central segments of the rift are expected to plot at the intersection of these vertical and horizontal bars, represented by the hypothetical red circles. 
In contrast, Figure 13B is constructed to test the hypothesis that the southern segment of the rift reactivated older structures, but also formed under regional EW extension. In this region, faults trend NW-SE (strike values of approximately $315^{\circ}$ and $135^{\circ}$ ), which are represented by the vertical blue bars. If faults of this orientation were reactivated under E-W extension, as is hypothesized for this project, rake values of these faults would be oblique and range from $135^{\circ}$ to $180^{\circ}$, represented by the horizontal blue bar. Thus, under EW extension, fault kinematic data collected from the southern rift should plot at the intersection of the vertical and horizontal blue bars, represented by the blue circles. The predicted shift from the northern/central rift to the southern rift is represented by the two arrows.

A) Northern/ Central Rift

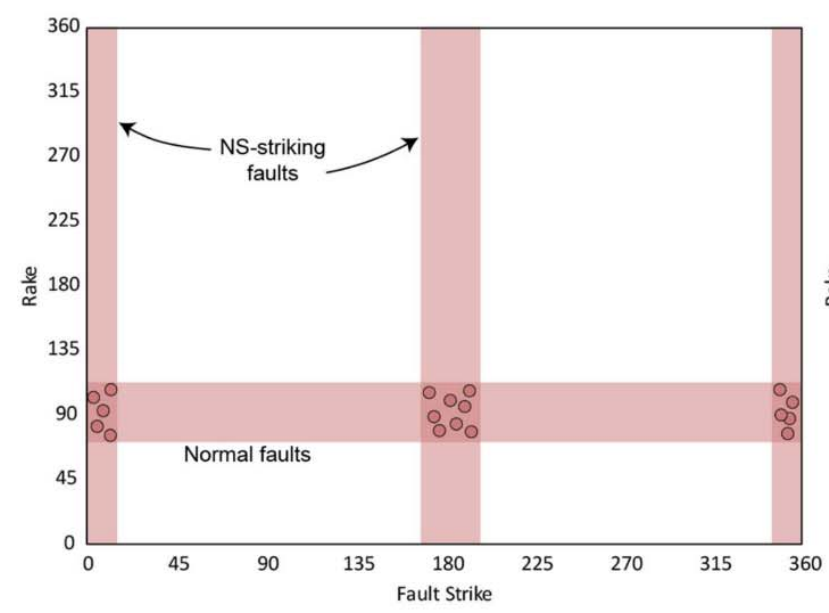

B) Southern Rift

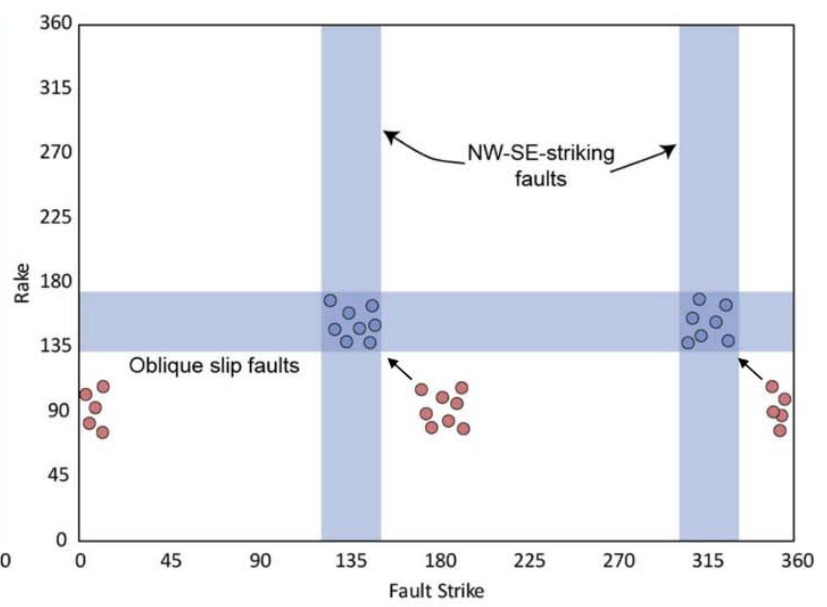

Fig. 13 Histogram showing expected fault orientation through the rift. X axis- Fault strike (vertical bars), Y axisRake (horizontal bars). Data are expected to plot at the intersection of the bars and should shift from N-S normal faults (north rift) to NW-SE oblique faults (south rift).

\section{COMPARING COMPILED AND COLLECTED DATA FOR BOTH SEGMENTS OF THE RIO GRANDE RIFT}


Figure 14A plots fault strike vs. rake for data compiled from the northern and central segments of the rift. The intersection of the blue vertical and horizontal bars represents the expected fault orientations of faults that are NS-trending and purely normal $\left(90^{\circ}\right)$ dip slip faults. The large data set $(n=1621)$ compiled from the northern/central Rio Grande rift shows some scatter, but generally plots as three discrete bull's eyes at the intersection of expected orientations for N-S striking normal faults that formed under regional EW extension. Data that do not fall into the bull's eyes are possibly related to transfer zones (strike of $045^{\circ}$, rake of $90^{\circ}$ )- especially in the Tusas-Abiquiu segment (central rift) where strains have been primarily accommodated in the adjacent San Luis and Española basins (Liu et al., 2019). These transfer zones may be an explanation to widespread fault values ranging from $000^{\circ}$ to $090^{\circ}$.

Figure 14B shows the same compiled data from the northern/central Rio Grande rift plotted as small black dots. Overlying these data are the data collected for this study from the southern Rio Grande rift ( $n=323$ ), color coded by location. Many of the fault measurements collected from the southern rift plot on top of the discrete bull's eyes from the northern/central rift data. However, there appears to be a larger spread in both strike and rake for data collected from the southern rift (Fig. 14B). More specifically, the data appear to form an array that spreads from the discrete bull's eyes to the predicted orientation of faults represented by the blue bars. This trend is highlighted by the red arrows. Southern New Mexico lies at the intersection of the NS-trending and the NW-SEtrending segments of the rift, so both fault populations are expected to be present. However, the shift in rake values from approximately 090 to $135-180$ suggests a transition from pure normal to more oblique-slip faults in the southern rift, consistent with regional EW extension. The results 
indicate that as the fault strikes rotate due to $\mathrm{E}-\mathrm{W}$ extension, the rake values also rotate to accommodate E-W extension.

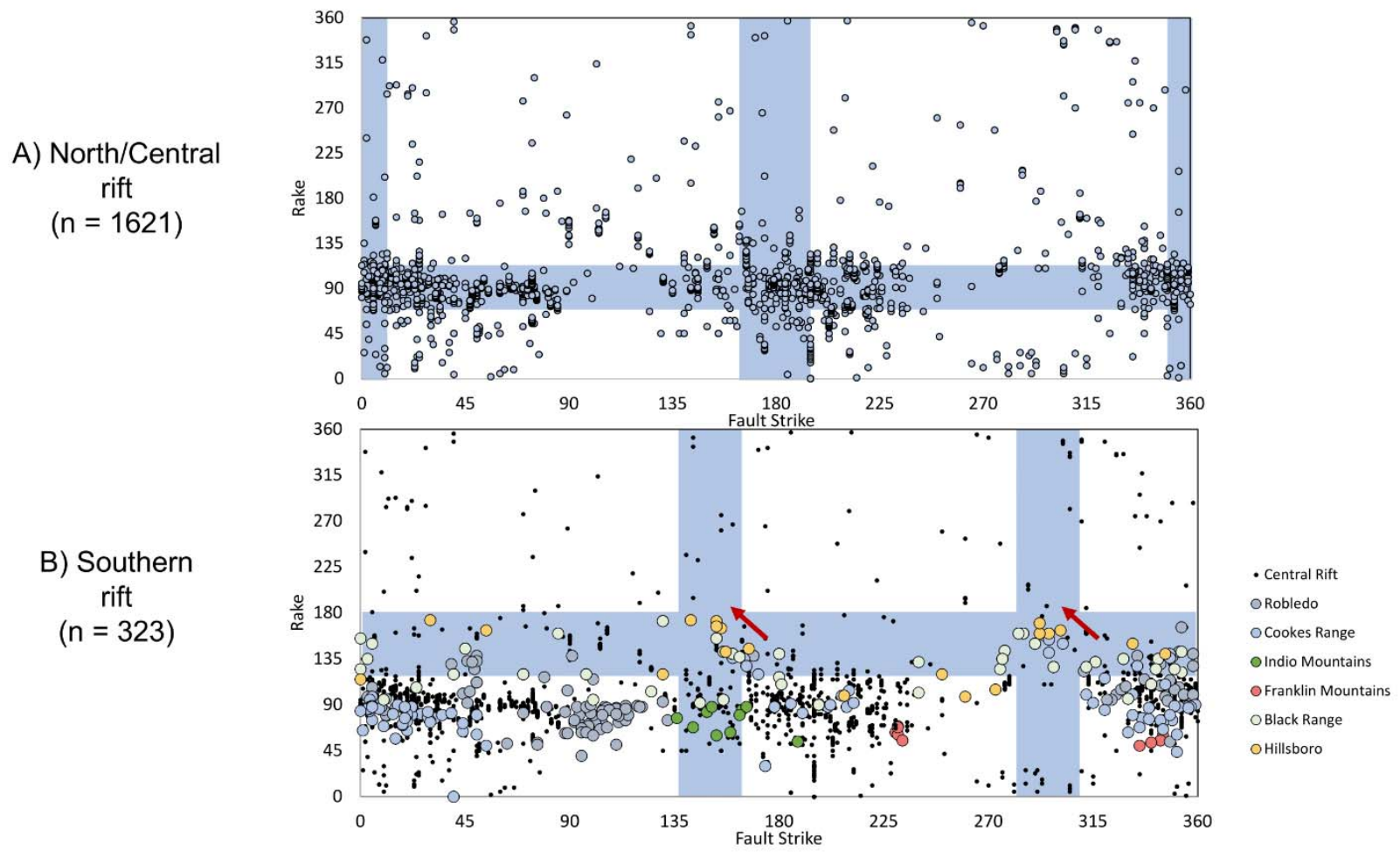

Fig. 14 Histograms showing expected fault orientation for the rift. $\mathrm{X}$ axis - strike, $\mathrm{Y}$ axis - rake. A) Scatter plots from northern/central rift overlaying the expected measurements bars. Data plot as 3 discrete bull's eyes at the intersection of the bars (as expected). B) Data collected from the southern rift (color coded by range) overlaying data from the northern rift (black dots) and bars. There is a shift in data from more N-S normal faults to NW-SE oblique faults, highlighted for the red arrow.

\section{COMPARING 2-D AND 3-D HISTOGRAMS FOR BOTH SEGMENTS OF THE RIFT}

The fault strike and rake data presented for both segments of the rift can also be visualized using 2-D and 3-D histograms. For the plots used in this section, the x-axis is fault strike and yaxis is fault rake. In the 3-D histograms the taller bars represent areas of higher density and in the 2-D ones, these areas are represented by warmer colors.

Figure 15A-B show the data compiled for the northern/central rift. The 3 bull's eyes are evident in both 2-D and 3-D plots at fault strikes of $0^{\circ}, 180^{\circ}$ and $360^{\circ}$ and fault rakes of $90^{\circ}$. Figure 
$15 \mathrm{C}$ shows the data collected from the southern rift in this study. The bull's eyes geometry is not apparent for the southern rift. Rather, there appears to be a wider spread in fault strike and rake values. The trend in fault kinematic data to more NW-trending oblique faults is highlighted by the white arrows in Figure 15D.
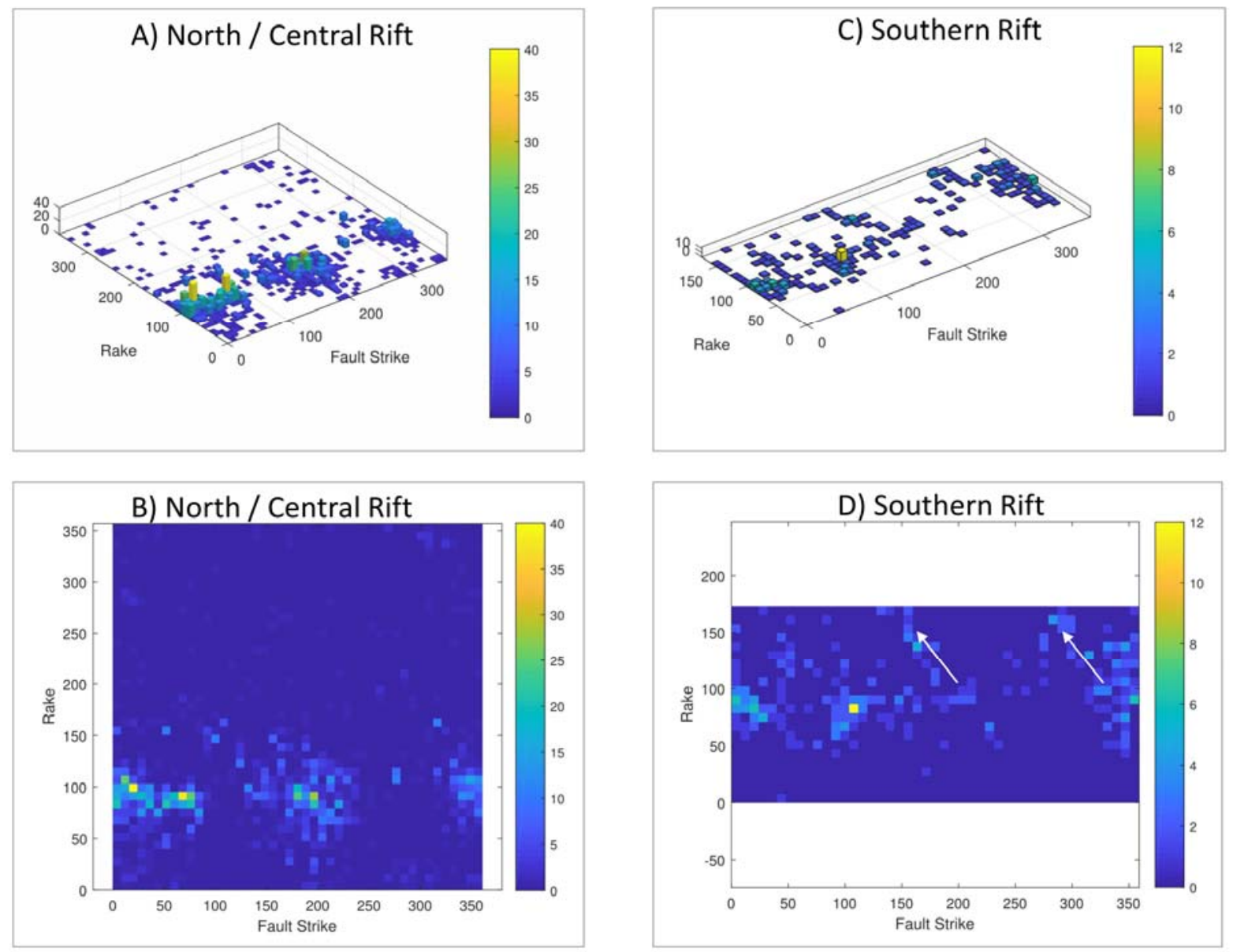

Fig. $15 \mathrm{~A}$ and C: 3-D Histograms fault data for the rift. B and D: bird-s eye view of the 3-D histograms. X axis strike, Y axis - rake. A and B: fault data for the northern rift plots as 3 discrete bull's eyes- indicating NW-trending normal faults. $\mathrm{C}$ and D: data for the southern rift spreads out towards more NW-trending oblique slip faults (highlighted by the white arrows).

\section{COLLECTED AND COMPILED DATA FOR BOTH SEGMENTS OF THE RIFT}

The trend to more oblique faults can also be represented using histograms and kernel density estimations (Vermeesch, 2012). The following histograms compare rake data compiled for 
the northern/central rift to rake data collected for the southern rift. The x-axis is fault rake and the $\mathrm{y}$-axis are number of measurements.

In Figure $16 \mathrm{~A}$, there is a single peak at $90^{\circ}$, representing pure normal faults for the northern/central rift. In Figure $16 \mathrm{~B}$, there is a similar peak at $86^{\circ}$ but there is also an additional peak at $131^{\circ}$. This may indicate that there is a transition from pure normal $\left(90^{\circ}\right)$ to more oblique slip faults $\left(135^{\circ}-180^{\circ}\right)$ under E-W extension, at the latitude of southern New Mexico. An

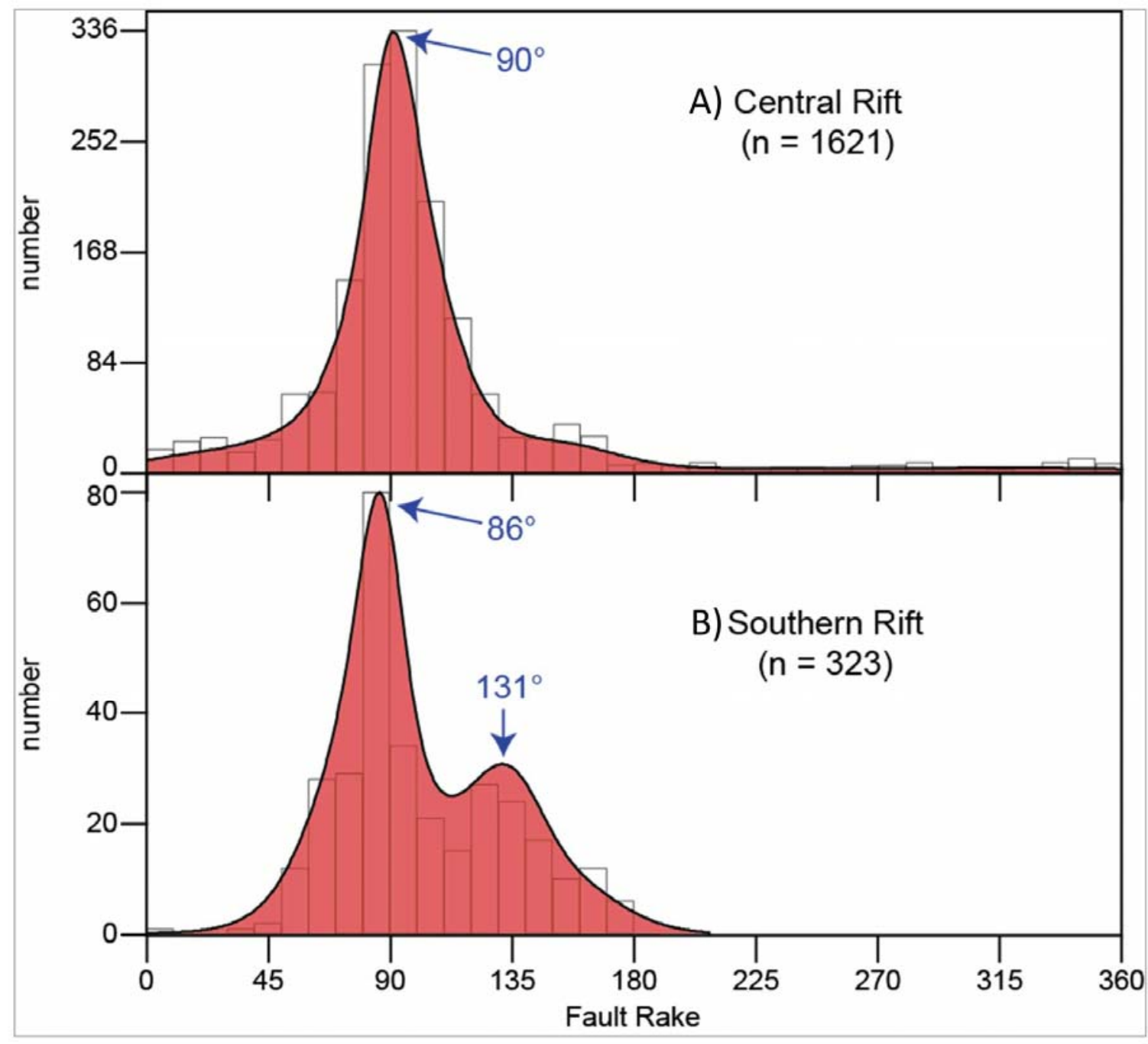

Fig. 16 Histograms and kernel density estimations showing rake trends throughout the rift. X: fault rake, Y: number of measurements. A) Central/northern: a single peak in rake data at $90^{\circ}$, indicating pure normal $\left(90^{\circ}\right)$ faults formed under E-W extension B) Southern: a similar peak to the norther rift at $96^{\circ}$ and a secondary peak at $131^{\circ}$, indicating pure normal and oblique slip $\left(135^{\circ}-180^{\circ}\right)$ faults formed under E-W extension. 
alternative possibility is that the measurements represent two generations of faults where the older generation faults is not recorded due to overprinting of younger generational faults. 


\section{CONCLUSION}

The Rio Grande rift preserves faults with a wide range of strike and rake orientations that range from N-S trending normal faults (northern/central rift) to NW-SE trending oblique faults (southern rift). Two models have been proposed for the opening of the southern rift. The first one suggests that extension began with a NE-SW orientation and later rotated to E-W. If extension

rotated, it may be possible that the older faults (formed under NE-SW extension) were overprinted by younger faults (formed under E-W extension). The second model suggests that the extension direction was constantly E-W throughout the rift. In this model, the southern rift likely reactivated older, underlying structures to produce a large bend in the rift as it continues into western Texas and northern Chihuahua. The results of this study cannot rule out the stress rotation model but rather endorses that the newly collected fault kinematic data from the southern Rio Grande rift, coupled with a synthesis of existing data from the northern/central segment of the rift are compatible with the second model where the entire Rio Grande rift formed under regional E-W extension. Previous studies have documented similar findings and have proposed similar geologic models to help explain the change in geometry through the Rio Grande rift. 


\section{REFERENCES}

Alaniz-Álvarez, S.A., Nieto-Samaniego, Á.F., and Mexicana, S.G., 2007, Geology of México: Celebrating the Centenary of the Geological Society of México: Geological Society of America, $478 \mathrm{p}$.

Aldrich, M.J., Chapin, C.E., and Laughlin, A.W., 1986, Stress history and tectonic development of the Rio Grande Rift, New Mexico: Journal of Geophysical Research: Solid Earth, v. 91, p. 61996211, doi:10.1029/JB091iB06p06199.

Amato, J.M., Lawton, T.F., Mauel, D.J., Leggett, W.J., González-León, C.M., Farmer, G.L., and Wooden, J.L., 2009, Testing the Mojave-Sonora megashear hypothesis: Evidence from Paleoproterozoic igneous rocks and deformed Mesozoic strata in Sonora, Mexico: Geology, v. 37, p. 75-78, doi:10.1130/G25240A.1.

Anderson, T.H., 2005, The Mojave-Sonora Megashear Hypothesis: Development, Assessment, and Alternatives: Geological Society of America, 726 p.

Armour, L.K., Langford, R.P., and Ricketts, J.W., 2018, Pliocene-Holocene deformation in the southern Rio Grande rift as inferred from topography and uplifted terraces of the Franklin Mountains, southern New Mexico and western Texas: Geosphere, v. 14, p. 1677-1689, doi:10.1130/GES01572.1.

Baldridge, W.S., Damon, P.E., Shafiqullah, M., and Bridwell, R.J., 1980, Evolution of the central Rio Grande rift, New Mexico: New potassium-argon ages: Earth and Planetary Science Letters, v. 51, p. 309-321, doi:10.1016/0012-821X(80)90213-7.

Bauer, P.W., and Ralser, S. The Picuris-Pecos fault--Repeatedly reactivated, from Proterozoic (?) to Neogene:, p. 7.

Berglund, H.T., Sheehan, A.F., Murray, M.H., Roy, M., Lowry, A.R., Nerem, R.S., and Blume, F., 2012, Distributed deformation across the Rio Grande Rift, Great Plains, and Colorado Plateau: Geology, v. 40, p. 23-26, doi:10.1130/G32418.1.

Bird, P., 1998, Kinematic history of the Laramide orogeny in latitudes $35^{\circ}-49^{\circ} \mathrm{N}$, western United States: Tectonics, v. 17, p. 780-801, doi:10.1029/98TC02698.

Burg, J.-P., 2017, Paleo-"Stress" Analysis from Fault Data.

Caine, J.S., Minor, S.A., Grauch, V.J.S., Budahn, J.R., and Keren, T.T., 2017, A comprehensive survey of faults, breccias, and fractures in and flanking the eastern Española Basin, Rio Grande rift, New Mexico: Geosphere, v. 13, p. 1566-1609, doi:10.1130/GES01348.1.

Carciumaru, D., and Ortega, R., 2008, Geologic structure of the northern margin of the Chihuahua trough: Evidence for controlled deformation during Laramide Orogeny: Boletín de la Sociedad Geológica Mexicana, v. 60.

Carciumaru, D., and Ortega, R., 2017, Paleostress and Geometric Analysis of the Southern Rio Grande Rift in the Northern Chihuahua Trough: Franklin and Potrillos Mountains as examples: Boletín de la Sociedad Geológica Mexicana, v. 69, p. 669-689, doi:10.18268/BSGM2017v69n3a9.

Chapin, C.E., 2013, Evolution of the Rio Grande Rift - A Summary, in Riecker, R.E. ed., Special Publications, Washington, D. C., American Geophysical Union, p. 1-6, doi:10.1029/SP014p0001.

Chapin, C.E., and Cather, S.M., 1983, Eocene Tectonics and Sedimentation in the Colorado Plateau Rocky Mountain Area:, http://archives.datapages.com/data/rmag/ForelandBasinUp83/chapin.htm (accessed October 2019).

Clarke, K., 1999, Getting started with GIS: 
Clemons, R.E., 1982, Geology of Massacre Peak Quadrangle, Luna County, New Mexico: New Mexico Bureau of Mines \& Mineral Resources.

Clemons, R.E., Mack, G.H., Lawton, T.F., and Lucas, S.G., 1988, Geology of southwestern New Mexico: Cretaceous and laramide tectonic evolution of southwestern New Mexico: New Mexico, New Mexico Geological Society, Guidebook, p. 45-57.

Coney, P.J., and Reynolds, S.J., 1977, Cordilleran Benioff zones: Nature, v. 270, p. 403-406, doi: $10.1038 / 270403 \mathrm{a} 0$.

Copeland, P., Currie, C.A., Lawton, T.F., and Murphy, M.A., 2017, Location, location, location: The variable lifespan of the Laramide orogeny: Geology, v. 45, p. 223-226, doi:10.1130/G38810.1.

De Sitter, L.U., 1956, Structural geology: McGraw-Hill New York, v. 552.

DeCelles, P.G., 2004, Late Jurassic to Eocene evolution of the Cordilleran thrust belt and foreland basin system, western U.S.A.: American Journal of Science, v. 304, p. 105-168, doi:10.2475/ajs.304.2.105.

Drewes, H., 1978, The Cordilleran orogenic belt between Nevada and Chihuahua: GSA Bulletin, v. 89, p. 641-657, doi:10.1130/0016-7606(1978)89<641:TCOBBN>2.0.CO;2.

Drewes, H., and Thorman, C.H., 1980, Geologic map of the Steins quadrangle and the adjacent part of the Vanar quadrangle, Hidalgo County, New Mexico: IMAP USGS Numbered Series 1220, http://pubs.er.usgs.gov/publication/i1220 (accessed March 2019).

Eaton, G.P., 1979, 1979 Basin and Range Symposium:

Elston, W.E., Seager, W.R., and Clemons, R.E., 1975, Emory cauldron, Black Range, New Mexico, source of the Kneeling Nun Tuff, in Field Conf Guide NM Geol Soc, v. 26, p. 283-292.

Faulds, J.E., and Stewart, J.H., 1998, Accommodation zones and transfer zones; the regional segmentation of the Basin and Range Province: Geological Society of America, $269 \mathrm{p}$.

Faulds, J.E., and Vargas, R.J., 1998, The role of accommodation zones and transfer zones in the regional segmentation of extended terranes: Geological Society of America.

Fossen, H., 2017, Structural Geology (2nd edition): Cambridge University Press, v. 23.

Haenggi, W.T., 2002, Tectonic history of the Chihuahua trough, Mexico and adjacent USA, Part II: Mesozoic and Cenozoic: Boletín de la Sociedad Geológica Mexicana, v. 55, p. 38-94, doi:10.18268/BSGM2002v55n1a4.

Harbour, R.L., 1972, Geology of the northern Franklin Mountains, Texas and New Mexico:

Hildebrand, R.S., 2015, Dismemberment and northward migration of the Cordilleran orogen: Baja-BC resolved: GSA Today, v. 25, p. 4-11.

Hills, J.M., 1972, Late Paleozoic Sedimentation in West Texas Permian Basin: AAPG Bulletin, v. 56, p. 2303-2322.

Humphreys, E.D., 1995, Post-Laramide removal of the Farallon slab, western United States: Geology, v. 23, p. 987-990, doi:10.1130/0091-7613(1995)023<0987:PLROTF>2.3.CO;2.

Ingersoll, R.V., 1990, Actualistic sandstone petrofacies: Discriminating modern and ancient source rocks: Geology, v. 18, p. 733-736, doi:10.1130/0091-

7613(1990)018<0733:ASPDMA>2.3.CO;2.

Jicha, H.L. Bulletin 37: Geology and Mineral Deposits of Lake Valley Quadrangle, Grant, Luna, and Sierra Counties, New Mexico: , p. 108.

Jones, W.R., Hernon, R.M., and Moore, S.L., 1967, General geology of Santa Rita quadrangle, Grant County, New Mexico: US Govt. Print. Off.,.

Keaton, J., and Barnes, J.B., 1996, Paleoseismic Evaluation of the East Franklin Mountains Fault, El Paso, Texas: Final Report, under award: US Geological Survey, National Earthquake Hazards Reduction Program, Program Element, v. 3, p. 1434-94. 
Kelley, S.A., 1997, Cooling histories of mountain ranges in the southern Rio Grande rift: , p. 14.

Kelley, S.A., Mine, T., Mine, C., and Valley, L. Cookes Peak:

Kelley, S.A., Seager, W.R., Cikoski, C.T., Jochems, A.P., and Koning, D.J., 2014, Geologic Map of the Hillsboro 7.5-Minute Quadrangle, Sierra County, New Mexico: , p. 1.

Kelson, K.I., Bauer, P.W., Unruh, J.R., and Bott, J.D.J., 2004, Late Quaternary characteristics of the northern Embudo fault, Taos County, New Mexico, in New Mexico Geological Society Guidebook: 55th Field Conference, Geology of the Taos Region, p. 147-157.

King, P.B., 1937, Geology of the Marathon region, Texas.:

King, W.E., and Hawley, J.W. GEOLOGY AND GROUND-WATER RESOURCES OF THE LAS CRUCES AREA, NEW MEXICO: , p. 12.

Koning, D.J., Ferguson, J.F., Paul, P.J., and Baldridge, W.S., 2004, Geologic structure of the Velarde Graben and the southern Embudo fault system, north-central N.M.: New Mexico Geol. Soc. 55th Field Conference Guidebook, v. Geology of the Taos Region., 158-171 p.

Koning, D.J., Rawling, G.C., Kelley, S., Goff, F., McIntosh, W., and Peters, L., 2014, Structure and tectonic evolution of the Sierra Blanca basin, in Geology of the Sacramento Mountains Region: New Mexico Geological Society 65th Field Conference Guidebook: Socorro, New Mexico, New Mexico Geologi cal Society, p. 209-226.

Kuellmer, F.J., 1954, Geologic Section of the Black Range at Kingson, New Mexico: New Mexico Bureau of Mines and Mineral Resources, New Mexico Institute of ....

Landman, R.L., and Flowers, R.M., 2013, (U-Th)/He thermochronologic constraints on the evolution of the northern Rio Grande Rift, Gore Range, Colorado, and implications for rift propagation models: , p. 18.

Lawton, T.F., 2000, Inversion of Late Jurassic-Early Cretaceous extensional faults of the Bisbee basin, southeastern Arizona and southwestern New Mexico: Southwest passage — a trip through the Phanerozoic: New Mexico Geological Society, Guidebook, v. 51, p. 95-102.

Liu, L., Gurnis, M., Seton, M., Saleeby, J., Muller, R.D., and Jackson, J.M. The role of oceanic plateau subduction in the Laramide orogeny | Nature Geoscience:, https://www.nature.com/articles/ngeo829 (accessed November 2019).

Liu, Y.A., Murphy, M.A., van Wijk, J., Koning, D.J., Smith, T., and Andrea, R.A., 2019, Progressive opening of the northern Rio Grande rift based on fault structure and kinematics of the TusasAbiquiu segment in north-central New Mexico, U.S.: Tectonophysics, v. 753, p. 15-35, doi:10.1016/j.tecto.2019.01.004.

Lovejoy, E.M.P., 1975, An interpretation of the structural geology of the Franklin Mountains, Texas, in New Mexico Geological Society, 26th Annual Field Conference Guidebook, p. 261-268.

Lucas, S.G., Corbitt, L.L., and Estep, J.W., 1998, Cretaceous stratigraphy and biostratigraphy, western Franklin Mountains, El Paso, Texas: New Mexico Geological Society Guidebook, v. 49, p. 197-203.

Machette, M.N., Personius, S.F., and Kelson, K.I., 1999, Quaternary faults in the Albuquerque area-An update: New Mexico Geological Society Guidebook, p. 14.

Mack, G.H., Galemore, J.A., and Kaczmarek, E.L. The Cretaceous foreland basin in southwestern New Mexico: , p. 10.

Mack, G.H., and Giles, K.A. (Eds.), 2004, The Geology of New Mexico: A Geologic History: 474 p., https://geoinfo.nmt.edu/publications/nmgs/special/11/SPL PUB 11.pdf.

Marrett, R., and Allmendinger, R.W., 1990, Kinematic analysis of fault-slip data: Journal of Structural Geology, v. 12, p. 973-986, doi:10.1016/0191-8141(90)90093-E. 
McCalpin, J., and Harrison, J.B.J., 2000, Paleoseismicity of Quaternary faults near Albuquerque, New Mexico: GEO-HAZ Consulting.

Minor, S.A., Hudson, M.R., and Caine, J.S., 2013, Oblique transfer of extensional strain between basins of the middle Rio Grande rift, New Mexico: fault kinematic and paleostress constraints, in New Perspectives on Rio Grande Rift Basins: From Tectonics to Groundwater, Geol. Soc. Am. Spec. Paper 494., p. 345-382, https://books.google.com/books?hl=en\&lr=\&id=YMUzJmFqlgUC\&oi=fnd\&pg=PA345\&dq=Mi nor, + S.A., + Hudson,,+ M.R., + Caine, + J.S., + Thompson,,+ R.A., $+2013 .+$ Oblique + transfer + of + extens ional + strain + between + basins + of + the + middle + Rio + Grande + rift,+ New + Mexico: + fault + kinemati c+and+paleostress+constraints.+In:+Hudson, + M.R., + Grauch, + V.J.S. $+($ Eds. $),+$ New + Perspec\&ot

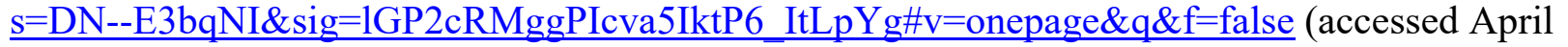
2019).

Moody, J.D., and Hill, M.J., 1956, Wrench-fault tectonics: Geological Society of America Bulletin, v. 67, p. 1207-1246.

Morgan, P., Seager, W.R., and Golombek, M.P., 1986, Cenozoic thermal, mechanical and tectonic evolution of the Rio Grande Rift: Journal of Geophysical Research: Solid Earth, v. 91, p. 62636276, doi:10.1029/JB091iB06p06263.

Muehlberger, W.R., 1980, Texas lineament revisited, in Trans-Pecos region, southeastern New Mexico and west Texas, New Mexico Geological Society Fall Field Conference Guidebook, v. 31, p. $113-121$.

Muehlberger, W.R., 1979, The Embudo fault between Pilar and Arroyo Hondo, New Mexico: an active intracontinental transform fault.:

Murray, K.D., Murray, M.H., and Sheehan, A.F., 2019, Active Deformation Near the Rio Grande Rift and Colorado Plateau as Inferred from Continuous Global Positioning System Measurements: Journal of Geophysical Research: Solid Earth, v. 124, p. 2166-2183, doi:10.1029/2018JB016626.

Olsen, K.H., Scott Baldridge, W., and Callender, J.F., 1987, Rio Grande rift: An overview: Tectonophysics, v. 143, p. 119-139, doi:10.1016/0040-1951(87)90083-7.

Price, J.G., and Henry, C.D., 1984, Stress orientations during Oligocene volcanism in Trans-Pecos Texas: Timing the transition from Laramide compression to Basin and Range tension: Geology, v. 12, p. 238-241, doi:10.1130/0091-7613(1984)12<238:SODOVI >2.0.CO;2.

Raney, J.A., and Collins, E.W., 1990, Regional Geologic Seting of the Fort Hancock Study Area: Hudspeth Country, Texas: Bureau of Economic Geology, Final Contract Report Prepared for Texas Low-Level Radioactive Waste Disposal Authority, p. 69.

Ricketts, J.W., Kelley, S.A., Karlstrom, K.E., Schmandt, B., Donahue, M.S., and Wijk, J. van, 2016, Synchronous opening of the Rio Grande rift along its entire length at 25-10 Ma supported by apatite (U-Th)/He and fission-track thermochronology, and evaluation of possible driving mechanisms: GSA Bulletin, v. 128, p. 397-424, doi:10.1130/B31223.1.

Scharman, M.R., 2006, Structural constraints on Laramide shortening and Rio Grande rift extension in the central Franklin Mountains, El Paso County, Texas [M.S.]: The University of Texas at El Paso, 80 p., https://search.proquest.com/docview/304960009/abstract/7003C00BC8544DD3PQ/1 (accessed October 2019).

Seager, W.R., and Morgan, P., 1979, Rio Grande Rift in Southern New Mexico, West Texas, and Northern Chihuahua, in Riecker, R.E. ed., Special Publications, Washington, D. C., American Geophysical Union, p. 87-106, doi:10.1029/SP014p0087. 
Seager, W.R., Shafiqullah, M., Hawley, J.W., and Marvin, R.F., 1984, New K-Ar dates from basalts and the evolution of the southern Rio Grande rift: GSA Bulletin, v. 95, p. 87-99, doi:10.1130/0016-7606(1984)95<87:NKDFBA>2.0.CO;2.

Sears, J.W., and Price, R.A., 1978, The Siberian connection: a case for Precambrian separation of the North American and Siberian cratons: Geology, v. 6, p. 267-270.

Smith, T.M., Sundell, K.E., Johnston, S.N., Andrade, C.N.G., Andrea, R.A., Dickinson, J.N., Liu, Y.A., Murphy, M.A., Lapen, T.J., and Saylor, J.E. Drainage reorganization and Laramide tectonics in north-central New Mexico and downstream effects in the Gulf of Mexico: Basin Research, v. n/a, doi: $10.1111 /$ bre. 12373 .

Underwood, J.R., 1962, Geology of Eagle Mountains and vicinity, Trans-Pecos Texas [Thesis], doi:10.15781/T2VX06K26.

Vermeesch, P., 2012, On the visualisation of detrital age distributions: Chemical Geology, v. $312-$ 313, p. 190-194, doi:10.1016/j.chemgeo.2012.04.021.

Wertz, J.B., 1970, The Texas lineament and its economic significance in southeast Arizona: Economic Geology, v. 65, p. 166-181.

Wilcox, R.E., Harding, T.P., and Seely, D.R., 1981, Basic Wrench Tectonics: , p. 74-74.

Zoback, M.L., Anderson, R.E., and Thompson, G.A., 1981, Cainozoic Evolution of the State of Stress and Style of Tectonism of the Basin and Range Province of the Western United States: Philosophical Transactions of the Royal Society A: Mathematical, Physical and Engineering Sciences, v. 300, p. 407-434, doi:10.1098/rsta.1981.0073. 


\section{APPENDIX}

\begin{tabular}{|c|c|c|c|c|c|c|c|c|}
\hline \multicolumn{9}{|c|}{ Black Range } \\
\hline $\begin{array}{l}\text { Fault } \\
\text { strike }\end{array}$ & $\begin{array}{l}\text { Fault } \\
\text { dip }\end{array}$ & $\begin{array}{l}\text { Striae } \\
\text { trend }\end{array}$ & $\begin{array}{l}\text { Striae } \\
\text { plunge }\end{array}$ & $\begin{array}{l}\text { Sense of } \\
\text { Slip }\end{array}$ & $\mathrm{T}$ trend & T plunge & $\mathrm{P}$ trend & $\begin{array}{l}\mathrm{P} \\
\text { plunge }\end{array}$ \\
\hline & & & & & 307.34 & 25.9773 & 216.65 & 1.4061 \\
\hline 85 & 73 & 258.9258 & 19.09137 & $\mathrm{TL}$ & 18 & 2 & 65 & 38 \\
\hline & & & & & 104.98 & 44.7823 & 275.01 & 44.782 \\
\hline 10 & 90 & 190 & 85 & NR & 11 & 8 & 89 & 38 \\
\hline & & & & & 84.890 & 7.17580 & & 18.185 \\
\hline 130 & 72 & 307.5132 & 7.606075 & $\mathrm{NR}$ & 41 & 7 & 352.52 & 94 \\
\hline & & & & & 283.55 & 11.5103 & 23.863 & 41.297 \\
\hline 160 & 71 & 324.7205 & 37.42826 & $\mathrm{NR}$ & 88 & 6 & 72 & 44 \\
\hline & & & & & 127.67 & 29.0163 & 272.41 & 55.810 \\
\hline 24 & 76 & 165.6458 & 68.10953 & NR & 49 & 1 & 32 & 93 \\
\hline & & & & & 284.23 & 25.8068 & 27.761 & 25.806 \\
\hline 156 & 90 & 336 & 38 & NR & 85 & 3 & 51 & 83 \\
\hline & & & & & 283.82 & 11.3918 & 18.783 & 23.224 \\
\hline 153 & 82 & 329.2869 & 24.74026 & NR & 38 & 4 & 84 & 71 \\
\hline & & & & & 69.851 & 44.1360 & 230.14 & 44.136 \\
\hline 330 & 90 & 150 & 80 & NR & 08 & 3 & 89 & 03 \\
\hline & & & & & 249.67 & 15.8597 & 53.454 & 73.517 \\
\hline 156 & 61 & 256.2295 & 60.60907 & NR & 33 & 8 & 27 & 88 \\
\hline & & & & & 104.95 & 19.1547 & 212.06 & 40.259 \\
\hline 343 & 77 & 150.3223 & 43.54971 & NR & 85 & 4 & 52 & 42 \\
\hline & & & & & 106.91 & 22.4282 & 226.93 & 50.473 \\
\hline 353 & 74 & 149.1972 & 54.60676 & NR & 45 & 2 & 03 & 99 \\
\hline & & & & & 104.92 & 15.7930 & 217.24 & 53.315 \\
\hline 350 & 68 & 141.8535 & 49.42054 & NR & 87 & 8 & 23 & 54 \\
\hline & & & & & 304.08 & & 46.226 & 38.465 \\
\hline 180 & 75 & 347.7471 & 38.3808 & NR & 01 & 14.834 & 37 & 61 \\
\hline & & & & & 237.84 & 39.9679 & 53.801 & 49.961 \\
\hline 146 & 85 & 257.8345 & 84.61578 & NR & 52 & 1 & 53 & 77 \\
\hline & & & & & 97.182 & 17.6049 & 210.98 & 51.826 \\
\hline 342 & 70 & 135.9666 & 50.33155 & NR & 86 & 1 & 72 & 33 \\
\hline & & & & & 314.23 & 14.4774 & 207.20 & 48.590 \\
\hline 5 & 45 & 162.7923 & 20.70485 & $\mathrm{NR}$ & 15 & 9 & 76 & 41 \\
\hline & & & & & 297.48 & 10.2556 & 193.31 & 53.547 \\
\hline 353 & 46 & 144.5101 & 26.28716 & NR & 94 & 8 & 09 & 93 \\
\hline & & & & & 104.43 & 7.44378 & 3.0028 & 56.609 \\
\hline 163 & 47 & 310.5447 & 29.91946 & NR & 56 & 8 & 3 & 37 \\
\hline & & & & & 359.14 & 13.7199 & 104.91 & 48.071 \\
\hline 240 & 69 & 38.29705 & 43.93051 & NR & 65 & 2 & 98 & 97 \\
\hline & & & & & 113.98 & 3.95058 & 211.34 & 61.649 \\
\hline 0 & 55 & 140.6773 & 42.14508 & NR & 8 & 2 & 12 & 07 \\
\hline & & & & & 310.48 & 9.25260 & 212.47 & 40.569 \\
\hline 0 & 55 & 165.026 & 20.25437 & NR & 92 & 7 & 15 & 66 \\
\hline
\end{tabular}




\begin{tabular}{|c|c|c|c|c|c|c|c|c|}
\hline 3 & 44 & 147.271 & 29.41935 & NR & 303.44 & 9.28356 & $\begin{array}{r}197.73 \\
81\end{array}$ & $\begin{array}{r}58.868 \\
11\end{array}$ \\
\hline & & & & & 29.211 & 8.51525 & 133.51 & 58.779 \\
\hline 275 & 60 & 59.47036 & 45.18664 & NR & 15 & 4 & 26 & 57 \\
\hline 240 & 90 & 60 & 20 & NR & $\begin{array}{r}13.219 \\
18\end{array}$ & $\begin{array}{r}13.9954 \\
5\end{array}$ & $\begin{array}{r}106.78 \\
08\end{array}$ & $\begin{array}{r}13.995 \\
45\end{array}$ \\
\hline 197 & 80 & 287 & 80 & NL & 287 & 35 & 107 & 55 \\
\hline 180 & 85 & 350.2933 & 62.57518 & NR & $\begin{array}{r}292.91 \\
71\end{array}$ & $\begin{array}{r}34.4725 \\
2\end{array}$ & $\begin{array}{r}63.698 \\
97\end{array}$ & $\begin{array}{r}43.572 \\
17\end{array}$ \\
\hline 285 & 65 & 96.25527 & 18.05776 & NR & $\begin{array}{r}236.80 \\
37 \\
\end{array}$ & 4.56847 & 144.03 & $\begin{array}{r}31.199 \\
67 \\
\end{array}$ \\
\hline 283 & 85 & 101.1831 & 19.92066 & NR & $\begin{array}{r}55.485 \\
83\end{array}$ & $\begin{array}{r}10.3287 \\
6\end{array}$ & $\begin{array}{r}148.80 \\
23\end{array}$ & 17.611 \\
\hline 40 & 80 & 203.2604 & 58.52505 & NR & $\begin{array}{r}153.77 \\
13\end{array}$ & $\begin{array}{r}28.7037 \\
8\end{array}$ & $\begin{array}{r}279.06 \\
93\end{array}$ & $\begin{array}{r}46.540 \\
18\end{array}$ \\
\hline 45 & 85 & 221.5077 & 34.84748 & NR & $\begin{array}{r}173.06 \\
06\end{array}$ & $\begin{array}{r}20.0236 \\
5\end{array}$ & $\begin{array}{r}274.11 \\
65\end{array}$ & $\begin{array}{r}27.753 \\
26\end{array}$ \\
\hline 290 & 65 & 96.28783 & 26.94622 & NR & $\begin{array}{r}57.771 \\
59 \\
\end{array}$ & $\begin{array}{r}1.23722 \\
7\end{array}$ & $\begin{array}{r}148.74 \\
76\end{array}$ & $\begin{array}{r}38.262 \\
44\end{array}$ \\
\hline 340 & 65 & 110.7359 & 58.39168 & NR & $\begin{array}{r}84.702 \\
84\end{array}$ & $\begin{array}{r}17.6602 \\
4\end{array}$ & $\begin{array}{r}216.11 \\
03\end{array}$ & $\begin{array}{r}64.295 \\
68\end{array}$ \\
\hline 277 & 63 & 78.11386 & 32.42676 & NR & $\begin{array}{r}41.449 \\
36 \\
\end{array}$ & $\begin{array}{r}3.33338 \\
9 \\
\end{array}$ & $\begin{array}{r}134.72 \\
39 \\
\end{array}$ & $\begin{array}{r}44.441 \\
87 \\
\end{array}$ \\
\hline 276 & 64 & 72.32874 & 39.4603 & NR & $\begin{array}{r}36.326 \\
81 \\
\end{array}$ & $\begin{array}{r}8.01439 \\
2 \\
\end{array}$ & $\begin{array}{r}135.78 \\
47 \\
\end{array}$ & $\begin{array}{r}49.408 \\
89 \\
\end{array}$ \\
\hline 100 & 90 & 280 & 85 & NR & $\begin{array}{r}194.98 \\
11\end{array}$ & $\begin{array}{r}44.7823 \\
8\end{array}$ & $\begin{array}{r}5.0189 \\
31\end{array}$ & $\begin{array}{r}44.782 \\
38 \\
\end{array}$ \\
\hline 97 & 84 & 266.7378 & 59.46074 & NR & $\begin{array}{r}211.74 \\
07\end{array}$ & $\begin{array}{r}32.3510 \\
3\end{array}$ & $\begin{array}{r}338.05 \\
31\end{array}$ & $\begin{array}{r}43.073 \\
07\end{array}$ \\
\hline 70 & 90 & 250 & 60 & NR & $\begin{array}{r}186.56 \\
51\end{array}$ & $\begin{array}{r}37.7612 \\
4\end{array}$ & $\begin{array}{r}313.43 \\
49\end{array}$ & $\begin{array}{r}37.761 \\
24\end{array}$ \\
\hline 181 & 65 & 311.7359 & 58.39168 & NR & $\begin{array}{r}285.70 \\
28\end{array}$ & $\begin{array}{r}17.6602 \\
4\end{array}$ & $\begin{array}{r}57.110 \\
27\end{array}$ & $\begin{array}{r}64.295 \\
68\end{array}$ \\
\hline 125 & 88 & 296.4039 & 76.84967 & NR & $\begin{array}{r}227.28 \\
06\end{array}$ & $\begin{array}{r}41.5969 \\
4\end{array}$ & $\begin{array}{r}21.883 \\
18\end{array}$ & $\begin{array}{r}45.499 \\
28\end{array}$ \\
\hline 298 & 45 & 74.82132 & 34.38289 & NR & $\begin{array}{r}233.32 \\
3 \\
\end{array}$ & $\begin{array}{r}5.77845 \\
7 \\
\end{array}$ & $\begin{array}{r}131.31 \\
11 \\
\end{array}$ & $\begin{array}{r}64.068 \\
54 \\
\end{array}$ \\
\hline 328 & 65 & 125.0902 & 39.85571 & TL & $\begin{array}{r}188.66 \\
57\end{array}$ & $\begin{array}{r}48.7630 \\
6\end{array}$ & $\begin{array}{r}88.401 \\
87\end{array}$ & $\begin{array}{r}8.8772 \\
25\end{array}$ \\
\hline 316 & 72 & 117.0579 & 44.97294 & TL & $\begin{array}{r}183.15 \\
32\end{array}$ & $\begin{array}{r}45.9119 \\
8\end{array}$ & $\begin{array}{r}75.541 \\
23\end{array}$ & $\begin{array}{r}16.335 \\
17\end{array}$ \\
\hline 312 & 88 & 129.3483 & 52.95371 & $\mathrm{TL}$ & $\begin{array}{r}190.22 \\
35 \\
\end{array}$ & $\begin{array}{r}36.0899 \\
2 \\
\end{array}$ & $\begin{array}{r}72.363 \\
62 \\
\end{array}$ & $\begin{array}{r}32.663 \\
14 \\
\end{array}$ \\
\hline \multicolumn{9}{|c|}{ Cookes Range } \\
\hline 50 & 65 & 117.4 & 63.20195 & NL & $\begin{array}{r}132.53 \\
65\end{array}$ & $\begin{array}{r}19.4101 \\
4\end{array}$ & 339.47 & $\begin{array}{r}68.434 \\
9\end{array}$ \\
\hline
\end{tabular}




\begin{tabular}{|c|c|c|c|c|c|c|c|c|}
\hline 210 & 61 & 327.2 & 58.06769 & NR & $\begin{array}{r}310.18 \\
99 \\
\end{array}$ & $\begin{array}{r}14.9093 \\
6 \\
\end{array}$ & $\begin{array}{r}89.114 \\
32 \\
\end{array}$ & 70.547 \\
\hline & & & & & 106.19 & 12.6548 & 315.35 & 75.580 \\
\hline 22 & 58 & 97.1 & 57.11285 & NL & 26 & 6 & 62 & 05 \\
\hline & & & & & 108.69 & & 308.43 & 59.047 \\
\hline 26 & 75 & 84.5 & 72.55424 & NL & 25 & 29.4437 & 67 & 44 \\
\hline & & & & & 105.60 & 22.7758 & 270.30 & 66.477 \\
\hline 11 & 68 & 116.7 & 67.23299 & NR & 63 & 2 & 81 & 04 \\
\hline & & & & & 109.91 & 24.9157 & 319.67 & 61.849 \\
\hline 30 & 71 & 84.7 & 67.12517 & NL & 36 & 9 & 34 & 18 \\
\hline & & & & & 297.53 & 14.9778 & 124.44 & 74.917 \\
\hline 209 & 60 & 295 & 59.93945 & NL & 44 & 2 & 86 & 44 \\
\hline & & & & & 303.49 & 12.5684 & & 75.245 \\
\hline 207 & 58 & 313.6 & 56.89384 & NR & 1 & 4 & 91.327 & 2 \\
\hline & & & & & 289.50 & 16.9767 & 115.87 & 72.924 \\
\hline 201 & 62 & 286.7 & 61.933 & NL & 55 & 2 & 32 & 01 \\
\hline 202 & 55 & 292 & 55 & $\mathrm{NL}$ & 292 & 10 & 112 & 80 \\
\hline & & & & & 303.46 & 15.9777 & 116.91 & 73.922 \\
\hline 212 & 61 & 306.1 & 60.9377 & NR & 38 & 6 & 24 & 63 \\
\hline & & & & & 91.858 & 16.3812 & 328.91 & 61.606 \\
\hline 20 & 65 & 62.2 & 55.23166 & NL & 97 & 1 & 59 & 12 \\
\hline & & & & & 97.567 & 25.9742 & 272.79 & 63.947 \\
\hline 6 & 71 & 102.1 & 70.89963 & NR & 25 & 3 & 07 & 21 \\
\hline & & & & & 285.50 & & 26.503 & 48.074 \\
\hline 165 & 66 & 322.8986 & 40.2 & NR & 97 & 9.71813 & 37 & 46 \\
\hline & & & & & 282.14 & 16.9208 & 27.523 & 41.077 \\
\hline 160 & 75 & 325.9889 & 42.1 & NR & 62 & 6 & 65 & 24 \\
\hline & & & & & 282.65 & & 40.347 & 57.144 \\
\hline 171 & 67 & 316.9 & 52.86966 & NR & 5 & 16.7061 & 04 & 31 \\
\hline & & & & & 101.33 & 26.5782 & 262.80 & 62.182 \\
\hline 5 & 72 & 119.5 & 70.34989 & NR & 02 & 4 & 13 & 13 \\
\hline & & & & & 266.35 & 30.9721 & 90.737 & 58.953 \\
\hline 178 & 76 & 259.8 & 75.86116 & $\mathrm{NL}$ & 35 & 6 & 99 & 69 \\
\hline & & & & & 97.768 & 20.8502 & 264.30 & \\
\hline 4 & 66 & 106.1 & 65.51809 & NR & 69 & 1 & 29 & 68.613 \\
\hline & & & & & 282.76 & 14.5613 & 31.728 & 51.369 \\
\hline 166 & 68 & 320.4212 & 46.9 & NR & 02 & 1 & 33 & 62 \\
\hline & & & & & 80.899 & 19.2882 & 324.02 & 52.255 \\
\hline 15 & 71 & 41.6 & 52.43965 & NL & 02 & 2 & 26 & 02 \\
\hline & & & & & 83.560 & 22.5953 & 298.78 & 63.002 \\
\hline 5 & 69 & 58.2 & 64.38732 & NL & 8 & 2 & 85 & 8 \\
\hline & & & & & 275.89 & 32.9918 & 93.620 & 56.987 \\
\hline 185 & 78 & 280.1 & 77.95369 & NR & 62 & 7 & 27 & 48 \\
\hline & & & & & 89.289 & 25.7665 & 283.54 & 63.524 \\
\hline 4 & 71 & 76.1 & 70.10771 & NL & 98 & 3 & 81 & 87 \\
\hline & & & & & 273.91 & 21.6083 & 114.63 & 67.048 \\
\hline 190 & 67 & 260.2 & 65.71766 & NL & 83 & 8 & 14 & 86 \\
\hline
\end{tabular}




\begin{tabular}{|c|c|c|c|c|c|c|c|c|}
\hline 29 & 62 & 94.64102 & 59.72926 & NL & $\begin{array}{r}110.19 \\
44 \\
\end{array}$ & $\begin{array}{r}16.1843 \\
3 \\
\end{array}$ & $\begin{array}{r}325.13 \\
55 \\
\end{array}$ & $\begin{array}{r}70.503 \\
43 \\
\end{array}$ \\
\hline & & & & & 273.97 & 3.66843 & 18.879 & 76.002 \\
\hline 18 & 43 & 81.54201 & 39.85664 & NL & 52 & 1 & 31 & 87 \\
\hline & & & & & 92.529 & 15.9775 & 279.11 & 73.921 \\
\hline 4 & 61 & 89.88011 & 60.9371 & NL & 1 & 5 & 22 & 87 \\
\hline & & & & & 91.157 & 5.92288 & 299.03 & 83.306 \\
\hline 4 & 51 & 87.6596 & 50.82796 & NL & 54 & 6 & 45 & 21 \\
\hline 16 & 48 & 106 & 48 & NR & 106 & 3 & 286 & 87 \\
\hline & & & & & 115.81 & 6.60517 & 9.2927 & 67.847 \\
\hline 44 & 55 & 93.62429 & 47.41286 & NL & 74 & 3 & 25 & 94 \\
\hline & & & & & 255.72 & 29.4193 & 4.2710 & 29.419 \\
\hline 40 & 46 & 40 & 0 & $\mathrm{NL}$ & 9 & 3 & 33 & 33 \\
\hline & & & & & 104.74 & 13.4568 & 318.39 & 73.963 \\
\hline 22 & 59 & 93.10099 & 57.58045 & NL & 68 & 9 & 08 & 84 \\
\hline & & & & & 97.628 & 4.61654 & 334.02 & \\
\hline 14 & 50 & 90.15792 & 49.16652 & NL & 42 & 9 & 01 & 81.7 \\
\hline & & & & & 98.596 & 9.67736 & 333.39 & 73.519 \\
\hline 20 & 56 & 82.85196 & 52.83718 & NL & 42 & 2 & 72 & 85 \\
\hline & & & & & 274.68 & 1.56097 & 11.251 & 76.595 \\
\hline 18 & 45 & 82.0361 & 41.95776 & NL & 54 & 2 & 62 & 9 \\
\hline & & & & & 290.58 & 5.01592 & 96.133 & 84.821 \\
\hline 22 & 40 & 109.3899 & 39.97072 & $\mathrm{NL}$ & 05 & 5 & 58 & 17 \\
\hline & & & & & 112.60 & 13.0844 & 334.33 & 72.700 \\
\hline 32 & 59 & 97.85547 & 56.63648 & NL & 13 & 7 & 7 & 08 \\
\hline & & & & & 108.59 & 9.67736 & 343.39 & 73.519 \\
\hline 30 & 56 & 92.85196 & 52.83718 & NL & 64 & 2 & 72 & 85 \\
\hline & & & & & 90.876 & 2.95868 & 307.93 & 86.294 \\
\hline 3 & 48 & 88.52161 & 47.91287 & NL & 33 & 2 & 25 & 46 \\
\hline & & & & & 68.326 & & 303.31 & 74.811 \\
\hline 349 & 55 & 53.96013 & 52.30155 & NL & 06 & 8.85367 & 1 & 92 \\
\hline 359 & 45 & 89 & 45 & NR & 89 & 0 & $\begin{array}{r}179.00 \\
69\end{array}$ & 90 \\
\hline & & & & & 90.171 & & & 86.496 \\
\hline 3 & 47 & 87.14579 & 46.85054 & NL & 12 & 1.92778 & 326.82 & 52 \\
\hline & & & & & 79.585 & 1.98193 & 296.03 & 87.536 \\
\hline 351 & 47 & 78.06881 & 46.96258 & NL & 08 & 9 & 83 & 49 \\
\hline & & & & & 56.728 & 9.13740 & 286.83 & 75.921 \\
\hline 336 & 55 & 44.0749 & 52.95449 & NL & 74 & 2 & 61 & 22 \\
\hline & & & & & 85.542 & & 272.81 & 75.912 \\
\hline 357 & 59 & 83.12115 & 58.94196 & NL & 77 & 13.9782 & 91 & 82 \\
\hline & & & & & 94.284 & 8.99494 & 279.50 & 80.968 \\
\hline 5 & 54 & 93.29903 & 53.98799 & NL & 11 & 6 & 87 & 14 \\
\hline & & & & & 80.572 & 7.98009 & 272.03 & 81.859 \\
\hline 352 & 53 & 78.67909 & 52.95371 & NL & 1 & 6 & 67 & 6 \\
\hline & & & & & 48.348 & 19.4781 & 301.78 & 38.864 \\
\hline 351 & 78 & 2.352788 & 42.8029 & NL & 48 & 9 & 79 & 41 \\
\hline
\end{tabular}




\begin{tabular}{|c|c|c|c|c|c|c|c|c|}
\hline 29 & 62 & 94.64102 & 59.72926 & $\mathrm{NL}$ & $\begin{array}{r}110.19 \\
44 \\
\end{array}$ & $\begin{array}{r}16.1843 \\
3 \\
\end{array}$ & $\begin{array}{r}325.13 \\
55 \\
\end{array}$ & $\begin{array}{r}70.503 \\
43 \\
\end{array}$ \\
\hline & & & & & 265.31 & 0.93579 & 358.82 & 75.030 \\
\hline 10 & 46 & 71.07522 & 42.1877 & $\mathrm{NL}$ & 89 & 19 & 13 & 48 \\
\hline & & & & & 95.162 & 4.92411 & 307.19 & 84.196 \\
\hline 8 & 50 & 91.79139 & 49.83395 & $\mathrm{NL}$ & 24 & 4 & 84 & 88 \\
\hline & & & & & 108.04 & 3.63999 & 2.6320 & 76.538 \\
\hline 30 & 50 & 94.56272 & 47.10244 & $\mathrm{NL}$ & 43 & 2 & 62 & 38 \\
\hline & & & & & 93.584 & 2.98163 & 300.12 & 86.667 \\
\hline 5 & 48 & 92.01254 & 47.96125 & $\mathrm{NL}$ & 01 & 4 & 39 & 91 \\
\hline & & & & & 102.82 & 10.4806 & 321.95 & 76.586 \\
\hline 20 & 56 & 92.49868 & 54.73026 & $\mathrm{NL}$ & 67 & 3 & 88 & 49 \\
\hline & & & & & 117.92 & 4.52686 & 357.54 & 81.102 \\
\hline 35 & 50 & 109.6602 & 48.97354 & $\mathrm{NL}$ & 48 & 3 & 63 & 07 \\
\hline & & & & & 79.287 & 6.99510 & 265.77 & 82.960 \\
\hline 350 & 52 & 78.376 & 51.98883 & $\mathrm{NL}$ & 61 & 1 & 9 & 21 \\
\hline & & & & & 243.05 & 2.23025 & 343.67 & 78.065 \\
\hline 345 & 44 & 51.97375 & 41.62904 & $\mathrm{NL}$ & 96 & 2 & 74 & 51 \\
\hline & & & & & 46.413 & 9.87178 & 249.38 & 79.297 \\
\hline 320 & 55 & 41.32742 & 54.68982 & $\mathrm{NL}$ & 54 & 9 & 07 & 17 \\
\hline & & & & & 85.652 & 12.8069 & 288.03 & 76.188 \\
\hline 0 & 58 & 78.78154 & 57.50117 & $\mathrm{NL}$ & 9 & 1 & 53 & 18 \\
\hline & & & & & 52.310 & 43.1505 & 252.02 & 45.121 \\
\hline 332 & 89 & 337.6526 & 79.95063 & $\mathrm{NL}$ & 77 & 3 & 14 & 03 \\
\hline & & & & & 225.32 & 11.4674 & 128.73 & 29.527 \\
\hline 174 & 78 & 180.8449 & 29.27972 & $\mathrm{NL}$ & 91 & 7 & 11 & 62 \\
\hline & & & & & 72.656 & 18.2776 & 307.72 & 60.020 \\
\hline 1 & 67 & 40.9605 & 56.53894 & $\mathrm{NL}$ & 43 & 9 & 93 & 02 \\
\hline & & & & & 41.116 & 7.29136 & 293.92 & 66.596 \\
\hline 330 & 56 & 17.66084 & 47.61891 & $\mathrm{NL}$ & 99 & 1 & 16 & 91 \\
\hline & & & & & 49.535 & 6.59088 & 299.82 & 71.090 \\
\hline 335 & 54 & 30.49652 & 48.59969 & $\mathrm{NL}$ & 03 & 8 & 29 & 75 \\
\hline & & & & & 58.803 & 14.9079 & 279.90 & 70.542 \\
\hline 339 & 61 & 41.78414 & 58.06403 & $\mathrm{NL}$ & 59 & 4 & 07 & 89 \\
\hline & & & & & 63.139 & 13.7657 & 288.04 & 70.919 \\
\hline 344 & 60 & 45.81321 & 56.77406 & $\mathrm{NL}$ & 12 & 5 & 52 & 41 \\
\hline & & & & & & 24.9025 & 339.18 & 59.103 \\
\hline 44 & 72 & 87.563 & 64.75717 & $\mathrm{NL}$ & 120.06 & 4 & 42 & 03 \\
\hline & & & & & 103.60 & 6.60415 & 331.00 & 80.294 \\
\hline 20 & 52 & 95.57299 & 51.10601 & $\mathrm{NL}$ & 66 & 5 & 44 & 06 \\
\hline & & & & & 263.87 & 0.03926 & 354.93 & 87.878 \\
\hline 356 & 45 & 81.76123 & 44.92153 & $\mathrm{NL}$ & 92 & 09 & 92 & 8 \\
\hline & & & & & 296.92 & 3.15838 & 32.581 & 60.775 \\
\hline 54 & 49 & 92.02045 & 35.3199 & $\mathrm{NL}$ & 15 & 7 & 96 & 25 \\
\hline & & & & & 99.701 & & 327.36 & 75.150 \\
\hline 19 & 56 & 86.56624 & 53.88051 & $\mathrm{NL}$ & 36 & 10.1243 & 47 & 52 \\
\hline
\end{tabular}




\begin{tabular}{|c|c|c|c|c|c|c|c|c|}
\hline 19 & 54 & 105.6 & 53.95199 & $\mathrm{NL}$ & $\begin{array}{r}107.56 \\
84 \\
\end{array}$ & $\begin{array}{r}8.97978 \\
5 \\
\end{array}$ & $\begin{array}{r}297.95 \\
04 \\
\end{array}$ & $\begin{array}{r}80.873 \\
25 \\
\end{array}$ \\
\hline & & & & & 123.35 & 0.71634 & 26.269 & 84.209 \\
\hline 39 & 46 & 117.5625 & 45.42556 & $\mathrm{NL}$ & 19 & 51 & 53 & 55 \\
\hline & & & & & $\begin{array}{r}58.152 \\
37\end{array}$ & $\begin{array}{r}7.09825 \\
7\end{array}$ & $\begin{array}{r}309.03 \\
21\end{array}$ & $\begin{array}{r}69.184 \\
71\end{array}$ \\
\hline 345 & 55 & 37.18022 & 48.44615 & $\mathrm{NL}$ & $\begin{array}{r}37 \\
246.87\end{array}$ & $\begin{array}{r}7 \\
5.03582\end{array}$ & $\begin{array}{r}21 \\
45.816\end{array}$ & $\begin{array}{r}71 \\
84.605\end{array}$ \\
\hline 339 & 40 & 65.08629 & 39.93414 & $\mathrm{NL}$ & 09 & 7 & 63 & 99 \\
\hline 29 & 60 & 105.2029 & 59.26835 & NL & $\begin{array}{r}113.88 \\
8\end{array}$ & $\begin{array}{r}14.7294 \\
1\end{array}$ & $\begin{array}{r}317.24 \\
21\end{array}$ & $\begin{array}{r}74.020 \\
71\end{array}$ \\
\hline 50 & 70 & 81.67544 & 55.2728 & NL & $\begin{array}{r}118.62 \\
74\end{array}$ & 19.8347 & $\begin{array}{r}357.12 \\
06\end{array}$ & $\begin{array}{r}55.385 \\
96\end{array}$ \\
\hline 348 & 62 & 57.41452 & 60.40449 & NL & $\begin{array}{r}70.644 \\
99\end{array}$ & $\begin{array}{r}16.4325 \\
6\end{array}$ & $\begin{array}{r}280.43 \\
33\end{array}$ & $\begin{array}{r}71.230 \\
32\end{array}$ \\
\hline 294 & 50 & 99.44172 & 16.67636 & NR & $\begin{array}{r}246.64 \\
16 \\
\end{array}$ & $\begin{array}{r}14.5724 \\
7 \\
\end{array}$ & $\begin{array}{r}143.53 \\
17 \\
\end{array}$ & $\begin{array}{r}41.104 \\
51 \\
\end{array}$ \\
\hline 296 & 46 & 97.28323 & 18.38121 & NR & $\begin{array}{r}247.27 \\
83 \\
\end{array}$ & $\begin{array}{r}15.5583 \\
8 \\
\end{array}$ & $\begin{array}{r}140.77 \\
48 \\
\end{array}$ & $\begin{array}{r}45.575 \\
64 \\
\end{array}$ \\
\hline 302 & 51 & 102.032 & 22.86571 & NR & $\begin{array}{r}250.42 \\
16\end{array}$ & $\begin{array}{r}9.80144 \\
6\end{array}$ & $\begin{array}{r}150.10 \\
37\end{array}$ & $\begin{array}{r}46.034 \\
59\end{array}$ \\
\hline 312 & 56 & 59.50132 & 54.73026 & NR & $\begin{array}{r}49.173 \\
31 \\
\end{array}$ & $\begin{array}{r}10.4806 \\
3 \\
\end{array}$ & $\begin{array}{r}190.04 \\
12 \\
\end{array}$ & $\begin{array}{r}76.586 \\
49 \\
\end{array}$ \\
\hline 296 & 70 & 100.5193 & 36.25413 & NR & $\begin{array}{r}59.936 \\
32 \\
\end{array}$ & $\begin{array}{r}10.1552 \\
2 \\
\end{array}$ & $\begin{array}{r}158.99 \\
02 \\
\end{array}$ & $\begin{array}{r}41.300 \\
25 \\
\end{array}$ \\
\hline 334 & 76 & 136.7951 & 49.87173 & NR & $\begin{array}{r}91.937 \\
73\end{array}$ & $\begin{array}{r}21.6904 \\
4\end{array}$ & $\begin{array}{r}205.70 \\
34\end{array}$ & $\begin{array}{r}45.375 \\
11\end{array}$ \\
\hline 346 & 69 & 121.4444 & 61.31579 & $\mathrm{TL}$ & $\begin{array}{r}226.18 \\
44 \\
\end{array}$ & 60.8955 & $\begin{array}{r}91.068 \\
78 \\
\end{array}$ & $\begin{array}{r}21.526 \\
11 \\
\end{array}$ \\
\hline 315 & 80 & 56.37056 & 79.80396 & NR & $\begin{array}{r}46.725 \\
72\end{array}$ & $\begin{array}{r}34.9703 \\
3\end{array}$ & $\begin{array}{r}222.53 \\
67\end{array}$ & $\begin{array}{r}54.957 \\
65\end{array}$ \\
\hline 348 & 25 & 130.7476 & 15.76272 & NR & $\begin{array}{r}295.31 \\
08\end{array}$ & $\begin{array}{r}26.6646 \\
7\end{array}$ & $\begin{array}{r}156.20 \\
64\end{array}$ & $\begin{array}{r}56.402 \\
44\end{array}$ \\
\hline 332 & 89 & 146.3474 & 79.95063 & NR & $\begin{array}{r}71.689 \\
23 \\
\end{array}$ & $\begin{array}{r}43.1505 \\
3 \\
\end{array}$ & $\begin{array}{r}231.97 \\
86 \\
\end{array}$ & $\begin{array}{r}45.121 \\
03 \\
\end{array}$ \\
\hline 348 & 87 & 165.1067 & 43.92422 & NR & $\begin{array}{r}112.80 \\
02\end{array}$ & $\begin{array}{r}26.9695 \\
8\end{array}$ & $\begin{array}{r}221.22 \\
04\end{array}$ & $\begin{array}{r}31.838 \\
82\end{array}$ \\
\hline 320 & 77 & 115.24 & 61.13481 & NR & $\begin{array}{r}70.434 \\
83 \\
\end{array}$ & $\begin{array}{r}27.3993 \\
7 \\
\end{array}$ & $\begin{array}{r}200.41 \\
63 \\
\end{array}$ & $\begin{array}{r}51.106 \\
91 \\
\end{array}$ \\
\hline \multicolumn{9}{|c|}{ Franklin Mountains } \\
\hline 290.7368 & $\begin{array}{r}86.065 \\
38\end{array}$ & 292.6762 & 26.19916 & NL & $\begin{array}{r}339.63 \\
8\end{array}$ & $\begin{array}{r}15.2874 \\
7\end{array}$ & 243.57 & $\begin{array}{r}21.143 \\
36\end{array}$ \\
\hline 300.0875 & $\begin{array}{r}74.177 \\
49\end{array}$ & 305.7657 & 19.24567 & $\mathrm{NL}$ & $\begin{array}{r}348.41 \\
64\end{array}$ & $\begin{array}{r}2.30835 \\
8\end{array}$ & $\begin{array}{r}257.32 \\
92\end{array}$ & $\begin{array}{r}25.206 \\
03\end{array}$ \\
\hline 297.4884 & $\begin{array}{r}84.501 \\
33 \\
\end{array}$ & 299.5093 & 20.11869 & NL & $\begin{array}{r}345.11 \\
15 \\
\end{array}$ & $\begin{array}{r}10.1056 \\
5 \\
\end{array}$ & $\begin{array}{r}251.76 \\
83 \\
\end{array}$ & $\begin{array}{r}18.118 \\
15 \\
\end{array}$ \\
\hline 302.5246 & $\begin{array}{r}85.290 \\
33\end{array}$ & 304.1038 & 18.49555 & NL & $\begin{array}{r}349.69 \\
74\end{array}$ & $\begin{array}{r}9.57031 \\
9\end{array}$ & $\begin{array}{r}256.85 \\
26\end{array}$ & $\begin{array}{r}16.401 \\
97\end{array}$ \\
\hline
\end{tabular}




\begin{tabular}{|c|c|c|c|c|c|c|c|c|}
\hline & 57.930 & & & & 115.12 & 3.43760 & 208.41 & 43.701 \\
\hline 242.1571 & 85 & 260.3573 & 26.49656 & NL & 54 & 2 & 64 & 75 \\
\hline & 46.091 & & & & 120.97 & 17.0468 & 227.85 & 43.441 \\
\hline 253.9718 & 56 & 270.2076 & 16.19613 & NL & 77 & 5 & 86 & 59 \\
\hline & 47.199 & & & & 119.84 & 19.5264 & 226.41 & 38.803 \\
\hline 255.8917 & 24 & 267.1771 & 11.9326 & NL & 95 & 8 & 85 & 13 \\
\hline & 50.909 & & & & 122.86 & 8.01165 & 222.11 & 48.794 \\
\hline 249.192 & 57 & 272.1926 & 25.68612 & NL & 78 & 4 & 79 & 56 \\
\hline & 53.385 & & & & 121.06 & 5.86456 & 217.58 & 47.842 \\
\hline 247.046 & 47 & 269.1596 & 26.86744 & NL & 96 & 5 & 37 & 26 \\
\hline \multicolumn{9}{|c|}{ Hillsboro Mountains } \\
\hline \multirow{3}{*}{346} & & & & & 288.81 & 1.90598 & 196.45 & 51.068 \\
\hline & 55 & 140.2991 & 31.77199 & NR & 82 & 9 & 72 & 69 \\
\hline & & & & & 283.43 & & 26.342 & 31.216 \\
\hline \multirow[t]{2}{*}{157} & 83 & 331.561 & 37.66709 & NR & 22 & 20.2379 & 29 & 15 \\
\hline & & & & & 287.71 & 5.64763 & 18.280 & 5.6476 \\
\hline \multirow[t]{2}{*}{153} & 90 & 333 & 8 & NR & 98 & 3 & 16 & 33 \\
\hline & & & & & 289.00 & 10.5452 & 20.992 & 10.545 \\
\hline \multirow[t]{2}{*}{155} & 90 & 335 & 15 & NR & 7 & 9 & 97 & 29 \\
\hline & & & & & 287.25 & 9.15259 & 18.743 & 9.1525 \\
\hline \multirow[t]{2}{*}{153} & 90 & 333 & 13 & NR & 63 & 6 & 73 & 96 \\
\hline & & & & & 96.685 & 3.59619 & 5.8298 & 13.374 \\
\hline \multirow[t]{2}{*}{142} & 78 & 320.5377 & 6.846293 & NR & 99 & 5 & 16 & 05 \\
\hline & & & & & 304.59 & 15.5466 & 96.433 & 72.486 \\
\hline \multirow[t]{2}{*}{208} & 61 & 316.0919 & 59.75184 & NR & 31 & 7 & 24 & 78 \\
\hline & & & & & 296.32 & 23.9274 & 37.677 & 23.927 \\
\hline \multirow[t]{2}{*}{167} & 90 & 347 & 35 & NR & 27 & 6 & 31 & 46 \\
\hline & & & & & 110.96 & 33.3604 & 244.40 & 46.240 \\
\hline \multirow[t]{2}{*}{0} & 83 & 165.3534 & 64.09928 & NR & 46 & 9 & 06 & 9 \\
\hline & & & & & 248.39 & & 151.35 & 35.436 \\
\hline \multirow[t]{2}{*}{296} & 58 & 105.0831 & 16.86092 & NR & 46 & 9.76535 & 95 & 86 \\
\hline & & & & & 244.28 & 9.02616 & 147.93 & 34.854 \\
\hline \multirow[t]{2}{*}{292} & 59 & 101.3826 & 17.04774 & NR & 31 & 8 & 16 & 07 \\
\hline & & & & & 250.29 & 21.1283 & 145.60 & 33.269 \\
\hline \multirow[t]{2}{*}{292} & 50 & 105.5336 & 7.64427 & NR & 25 & 6 & 49 & 68 \\
\hline & & & & & 15.132 & 29.4497 & 163.64 & 56.489 \\
\hline \multirow[t]{2}{*}{273} & 76 & 50.92223 & 69.59206 & NR & 27 & 3 & 05 & 94 \\
\hline & & & & & 356.78 & 33.5344 & 160.04 & 55.313 \\
\hline \multirow[t]{2}{*}{260} & 79 & 26.37359 & 76.42758 & NR & 02 & 2 & 19 & 94 \\
\hline & & & & & 3.9972 & 29.6181 & 129.59 & 45.680 \\
\hline \multirow[t]{2}{*}{250} & 81 & 54.83958 & 58.79988 & NR & 31 & 5 & 95 & 01 \\
\hline & & & & & 257.57 & 21.4098 & 147.86 & 40.712 \\
\hline \multirow[t]{2}{*}{301} & 44 & 108.5967 & 11.71823 & NR & 97 & 9 & 1 & 41 \\
\hline & & & & & 164.61 & 2.09975 & 254.89 & 7.7753 \\
\hline \multirow[t]{2}{*}{30} & 86 & 209.5093 & 6.982863 & NR & 24 & 5 & 93 & 89 \\
\hline & & & & & 187.72 & 11.9312 & 280.27 & 11.931 \\
\hline 54 & 90 & 234 & 17 & NR & 05 & 6 & 95 & 26 \\
\hline
\end{tabular}




\begin{tabular}{|c|c|c|c|c|c|c|c|c|}
\hline 332 & 80 & 146.2749 & 29.4987 & NR & $\begin{array}{r}100.94 \\
3\end{array}$ & $\begin{array}{r}13.0260 \\
6\end{array}$ & $\begin{array}{r}198.03 \\
79\end{array}$ & $\begin{array}{r}28.097 \\
27\end{array}$ \\
\hline & & & & & 241.55 & 15.7728 & 358.30 & 57.890 \\
\hline 130 & 66 & 274.8357 & 52.29348 & NR & 45 & 4 & 58 & 79 \\
\hline \multicolumn{9}{|c|}{ Indio Mountains } \\
\hline & & & & & 234.01 & 7.75652 & 90.190 & 80.421 \\
\hline 149 & 53 & 227.4686 & 52.43692 & NL & 07 & 4 & 4 & 56 \\
\hline & & & & & 250.40 & 10.8698 & 91.768 & 78.349 \\
\hline 164 & 56 & 245.1079 & 55.6781 & NL & 21 & 2 & 46 & 16 \\
\hline & & & & & 33.427 & 43.0495 & 212.52 & 46.946 \\
\hline 136 & 2 & 212.9923 & 1.94872 & NL & 85 & 7 & 62 & 89 \\
\hline & & & & & 251.60 & 20.7931 & 136.52 & 48.142 \\
\hline 188 & 74 & 208.7759 & 51.04838 & NL & 33 & 8 & 57 & 42 \\
\hline & & & & & 221.10 & 18.5598 & 101.73 & 55.598 \\
\hline 153 & 69 & 184.8283 & 53.95006 & NL & 23 & 2 & 93 & 97 \\
\hline & & & & & 216.98 & 16.2178 & 90.266 & 64.058 \\
\hline 143 & 64 & 190.3347 & 56.44414 & NL & 65 & 5 & 22 & 45 \\
\hline & & & & & & & 63.347 & 52.959 \\
\hline 151 & 82 & 226.9144 & 81.75537 & NL & 239.23 & 36.9694 & 89 & 41 \\
\hline & & & & & 254.20 & 37.9689 & 78.295 & 51.960 \\
\hline 166 & 83 & 240.0107 & 82.72126 & NL & 62 & 2 & 17 & 23 \\
\hline & & & & & 229.41 & 16.7359 & 108.47 & 59.674 \\
\hline 159 & 66 & 197.5992 & 54.48613 & NL & 41 & 2 & 93 & 79 \\
\hline & & & & & 245.77 & 12.4648 & 101.02 & 74.853 \\
\hline 163 & 58 & 234.5955 & 56.63295 & NL & 58 & 6 & 95 & 28 \\
\hline \multicolumn{9}{|c|}{ Robledo Mountains } \\
\hline & & & & & 63.700 & 3.67771 & 161.12 & 63.559 \\
\hline 311 & 54 & 88.85144 & 42.72644 & NR & 41 & 3 & 7 & 6 \\
\hline & & & & & 222.32 & 23.9432 & 34.805 & 65.872 \\
\hline 130 & 69 & 228.32 & 68.79638 & NR & 06 & 7 & 62 & 87 \\
\hline & & & & & 93.924 & 4.52686 & 333.54 & 81.102 \\
\hline 11 & 50 & 85.66019 & 48.97354 & NL & 8 & 3 & 63 & 06 \\
\hline & & & & & 64.377 & 6.88810 & 304.98 & 76.173 \\
\hline 345 & 53 & 50.99969 & 50.48182 & NL & 15 & 4 & 03 & 94 \\
\hline & & & & & 53.230 & 7.24806 & 311.15 & 58.708 \\
\hline 348 & 59 & 23.33241 & 43.90486 & NL & 11 & 1 & 17 & 87 \\
\hline & & & & & 107.00 & 44.9215 & 292.99 & 44.921 \\
\hline 20 & 90 & 20 & 87 & NL & 41 & 3 & 59 & 53 \\
\hline & & & & & 170.29 & 31.1409 & 281.70 & 31.140 \\
\hline 46 & 90 & 226 & 47 & NR & 39 & 5 & 61 & 95 \\
\hline & & & & & 168.83 & 35.3962 & 289.16 & 35.396 \\
\hline 49 & 90 & 229 & 55 & NR & 76 & 6 & 24 & 26 \\
\hline & & & & & 159.68 & 38.1492 & 298.48 & 43.766 \\
\hline 50 & 87 & 222.6192 & 67.80646 & NR & 4 & 7 & 17 & 94 \\
\hline & & & & & 144.45 & 41.9910 & 302.81 & 45.920 \\
\hline 44 & 88 & 213.8214 & 78.82186 & NR & 89 & 7 & 67 & 07 \\
\hline
\end{tabular}




\begin{tabular}{|c|c|c|c|c|c|c|c|c|}
\hline 46 & 89 & 199.4454 & 87.76402 & NR & $\begin{array}{r}137.96 \\
48 \\
\end{array}$ & $\begin{array}{r}43.9657 \\
1 \\
\end{array}$ & $\begin{array}{r}313.96 \\
55 \\
\end{array}$ & $\begin{array}{r}45.964 \\
49 \\
\end{array}$ \\
\hline & & & & & 160.53 & 40.9665 & 299.46 & 40.966 \\
\hline 50 & 90 & 230 & 68 & NR & 63 & 3 & 37 & 53 \\
\hline & & & & & 63.095 & 29.3158 & 221.27 & 58.831 \\
\hline 325 & 75 & 89.26563 & 72.03614 & NR & 44 & 4 & 6 & 5 \\
\hline & & & & & 70.660 & 39.1995 & 221.45 & 46.942 \\
\hline 327 & 86 & 132.4078 & 74.48768 & NR & 05 & 9 & 11 & 95 \\
\hline & & & & & 56.894 & 24.8402 & 224.72 & 64.659 \\
\hline 323 & 70 & 67.34857 & 69.40933 & NR & 03 & 6 & 11 & 37 \\
\hline & & & & & 87.304 & 30.5528 & 219.94 & 48.930 \\
\hline 337 & 80 & 136.5752 & 63.19404 & NR & 89 & 2 & 38 & 06 \\
\hline & & & & & 55.600 & 39.7998 & 225.52 & 49.761 \\
\hline 321 & 85 & 96.10922 & 82.93343 & NR & 95 & 1 & 54 & 66 \\
\hline & & & & & 73.576 & 29.7487 & 216.88 & 54.520 \\
\hline 329 & 77 & 114.3041 & 67.92319 & NR & 77 & 7 & 45 & 84 \\
\hline & & & & & 94.881 & 41.6411 & 237.11 & 41.641 \\
\hline 346 & 90 & 166 & 70 & NR & 72 & 4 & 83 & 14 \\
\hline & & & & & 99.714 & 25.8165 & 206.36 & 30.630 \\
\hline 334 & 87 & 151.302 & 41.92934 & NR & 35 & 6 & 03 & 9 \\
\hline & & & & & 88.561 & 23.6998 & 226.95 & 59.583 \\
\hline 344 & 71 & 120.6041 & 63.38094 & NR & 27 & 7 & 36 & 58 \\
\hline & & & & & 292.45 & & 36.948 & 38.322 \\
\hline 169 & 77 & 337.5498 & 40.69112 & NR & 02 & 17.5751 & 26 & 31 \\
\hline & & & & & 95.674 & 29.0163 & 240.41 & 55.810 \\
\hline 352 & 76 & 133.6458 & 68.10953 & NR & 89 & 1 & 32 & 93 \\
\hline & & & & & 306.89 & 8.26774 & 212.64 & 26.992 \\
\hline 353 & 65 & 166.9849 & 12.66532 & NR & 26 & 1 & 8 & 47 \\
\hline & & & & & 92.656 & 33.3566 & 242.42 & 52.695 \\
\hline 350 & 80 & 137.0542 & 72.03613 & NR & 62 & 1 & 38 & 32 \\
\hline & & & & & 115.58 & 19.9205 & 228.39 & 46.930 \\
\hline 358 & 74 & 158.5672 & 49.24294 & NR & 37 & 9 & 43 & 63 \\
\hline & & & & & 101.50 & 10.1880 & 205.21 & 52.828 \\
\hline 344 & 64 & 136.4161 & 43.51273 & NR & 34 & 2 & 33 & 39 \\
\hline & & & & & 108.54 & & 252.85 & 56.739 \\
\hline 5 & 75 & 144.7501 & 67.47605 & NR & 69 & 28.0444 & 53 & 02 \\
\hline & & & & & 99.213 & 24.5918 & 259.96 & 64.137 \\
\hline 3 & 70 & 115.3384 & 68.52034 & NR & 1 & 7 & 19 & 22 \\
\hline & & & & & 93.117 & 39.2041 & 253.20 & 49.055 \\
\hline 354 & 85 & 147.6975 & 78.83105 & NR & 32 & 9 & 08 & 33 \\
\hline & & & & & 80.143 & 25.8962 & 250.58 & 63.787 \\
\hline 347 & 71 & 89.12205 & 70.59874 & NR & 16 & 2 & 82 & 94 \\
\hline & & & & & 111.47 & & 215.59 & 41.183 \\
\hline 349 & 74 & 154.585 & 40.96356 & NR & 17 & 15.5845 & 6 & 24 \\
\hline & & & & & 99.448 & 28.3711 & 218.79 & 42.221 \\
\hline 342 & 82 & 150.7584 & 54.21139 & NR & 08 & 2 & 24 & 71 \\
\hline
\end{tabular}




\begin{tabular}{|c|c|c|c|c|c|c|c|c|}
\hline & & & & & 122.74 & 18.1343 & 226.27 & 35.527 \\
\hline 358 & 79 & 168.9037 & 39.1223 & NR & 93 & 6 & 31 & 32 \\
\hline & & & & & 96.018 & 28.3257 & 253.87 & 59.802 \\
\hline 358 & 74 & 120.6073 & 71.20155 & NR & 31 & 1 & 04 & 11 \\
\hline & & & & & 96.851 & 27.1113 & 229.50 & 52.925 \\
\hline 348 & 76 & 139.4819 & 62.42542 & NR & 04 & 5 & 55 & 33 \\
\hline & & & & & 118.01 & 18.6243 & 220.52 & 32.724 \\
\hline 352 & 81 & 165.0319 & 37.45092 & NR & 52 & 9 & 21 & 12 \\
\hline & & & & & 176.30 & 27.4344 & 283.05 & 29.039 \\
\hline 50 & 89 & 229.0997 & 41.99214 & NR & 39 & 8 & 53 & 69 \\
\hline & & & & & 173.96 & 30.3131 & 285.35 & 31.965 \\
\hline 50 & 89 & 228.9278 & 46.99064 & NR & 04 & 4 & 85 & 4 \\
\hline & & & & & 171.78 & 31.7007 & 284.21 & 31.700 \\
\hline 48 & 90 & 228 & 48 & NR & 77 & 5 & 23 & 75 \\
\hline & & & & & 328.36 & 36.2010 & 152.59 & 53.724 \\
\hline 47 & 9 & 150.1564 & 8.76749 & NR & 84 & 4 & 52 & 56 \\
\hline & & & & & 192.77 & 37.2270 & 323.88 & 40.868 \\
\hline 79 & 88 & 255.0817 & 62.93158 & NR & 63 & 6 & 02 & 91 \\
\hline & & & & & 217.30 & 27.4344 & 324.05 & 29.039 \\
\hline 91 & 89 & 270.0997 & 41.99214 & NR & 39 & 8 & 53 & 69 \\
\hline & & & & & 158.90 & 24.2461 & 271.96 & 41.013 \\
\hline 39 & 80 & 207.3079 & 48.97354 & NR & 03 & 9 & 05 & 27 \\
\hline & & & & & 159.57 & 3.24735 & 61.497 & 68.021 \\
\hline 89 & 52 & 138.1848 & 44.08877 & $\mathrm{NL}$ & 94 & 8 & 84 & 38 \\
\hline & & & & & 102.00 & 44.9215 & 287.99 & 44.921 \\
\hline 15 & 90 & 15 & 87 & $\mathrm{NL}$ & 41 & 3 & 59 & 53 \\
\hline & & & & & 95.399 & 39.7998 & 285.47 & 49.761 \\
\hline 10 & 85 & 54.89078 & 82.93343 & $\mathrm{NL}$ & 05 & 1 & 46 & 66 \\
\hline & & & & & 106.46 & 36.8777 & 294.68 & 52.837 \\
\hline 20 & 82 & 83.32299 & 81.06155 & $\mathrm{NL}$ & 47 & 3 & 37 & 91 \\
\hline & & & & & 106.46 & 36.8777 & 294.68 & 52.837 \\
\hline 20 & 82 & 83.32299 & 81.06155 & $\mathrm{NL}$ & 47 & 3 & 37 & 91 \\
\hline & & & & & 97.154 & 39.9679 & 281.19 & 49.961 \\
\hline 9 & 85 & 77.16546 & 84.61578 & $\mathrm{NL}$ & 8 & 1 & 85 & 77 \\
\hline & & & & & 102.10 & 42.9241 & 288.10 & 46.918 \\
\hline 15 & 88 & 48.66052 & 86.39496 & $\mathrm{NL}$ & 31 & 7 & 58 & 7 \\
\hline & & & & & 94.412 & 34.9332 & 280.69 & 54.904 \\
\hline 7 & 80 & 80.20596 & 79.56408 & $\mathrm{NL}$ & 76 & 8 & 05 & 78 \\
\hline & & & & & 84.260 & & 267.41 & 72.981 \\
\hline 355 & 62 & 82.87071 & 61.98359 & $\mathrm{NL}$ & 62 & 16.9943 & 65 & 38 \\
\hline & & & & & 85.237 & 21.9938 & 267.88 & 67.984 \\
\hline 356 & 67 & 83.44214 & 66.97945 & $\mathrm{NL}$ & 41 & 7 & 66 & 84 \\
\hline & & & & & 193.49 & 12.5662 & 45.727 & 75.236 \\
\hline 110 & 58 & 183.3594 & 56.8883 & $\mathrm{NL}$ & 26 & 4 & 19 & 79 \\
\hline & & & & & 207.38 & 0.17774 & 297.92 & 71.694 \\
\hline 100 & 48 & 224.8721 & 42.33916 & NR & 78 & 9 & 51 & 6 \\
\hline
\end{tabular}




\begin{tabular}{|c|c|c|c|c|c|c|c|c|}
\hline 89 & 58 & 204.1971 & 55.37186 & NR & $\begin{array}{r}189.07 \\
03 \\
\end{array}$ & $\begin{array}{r}11.9547 \\
2 \\
\end{array}$ & $\begin{array}{r}323.07 \\
29 \\
\end{array}$ & $\begin{array}{r}73.049 \\
61 \\
\end{array}$ \\
\hline & & & & & 222.32 & 23.9432 & 34.805 & 65.872 \\
\hline 130 & 69 & 228.32 & 68.79638 & NR & 06 & 7 & 62 & 87 \\
\hline & & & & & 168.09 & 41.9668 & 352.11 & 47.963 \\
\hline 80 & 87 & 136.2871 & 86.39496 & $\mathrm{NL}$ & 8 & 4 & 21 & 18 \\
\hline & & & & & 126.48 & 12.7929 & 19.072 & 52.810 \\
\hline 63 & 66 & 90.50145 & 46.04488 & $\mathrm{NL}$ & 58 & 4 & 55 & 52 \\
\hline & & & & & 133.08 & 10.5990 & 28.431 & 53.502 \\
\hline 70 & 64 & 98.4286 & 44.30631 & $\mathrm{NL}$ & 16 & 3 & 64 & 73 \\
\hline & & & & & 140.56 & 7.78806 & 38.206 & 57.417 \\
\hline 76 & 60 & 109.5652 & 43.75999 & $\mathrm{NL}$ & 36 & 6 & 4 & 4 \\
\hline & & & & & 9.0193 & 5.16514 & 123.65 & 77.766 \\
\hline 111 & 41 & 178.9473 & 38.858 & $\mathrm{NL}$ & 9 & 9 & 98 & 92 \\
\hline & & & & & 170.06 & 0.70490 & 76.851 & 77.632 \\
\hline 92 & 47 & 157.8539 & 44.37864 & $\mathrm{NL}$ & 78 & 58 & 16 & 51 \\
\hline & & & & & 338.59 & 2.41208 & 75.277 & 70.103 \\
\hline 88 & 46 & 140.5686 & 39.43031 & $\mathrm{NL}$ & 39 & 5 & 59 & 5 \\
\hline & & & & & 159.61 & 0.41769 & 68.509 & 69.243 \\
\hline 89 & 49 & 139.9766 & 41.78743 & $\mathrm{NL}$ & 13 & 92 & 04 & 94 \\
\hline & & & & & 170.99 & 2.15326 & 72.995 & 74.879 \\
\hline 95 & 49 & 155.9792 & 45.16945 & $\mathrm{NL}$ & 44 & 5 & 6 & 71 \\
\hline & & & & & 1.3782 & 0.42644 & 93.247 & 77.149 \\
\hline 104 & 46 & 168.9326 & 43.16744 & $\mathrm{NL}$ & 2 & 09 & 9 & 2 \\
\hline & & & & & 174.43 & 11.0859 & 51.174 & 70.338 \\
\hline 98 & 58 & 154.9852 & 53.30666 & $\mathrm{NL}$ & 26 & 1 & 92 & 97 \\
\hline & & & & & 139.30 & & 37.652 & 55.430 \\
\hline 76 & 61 & 106.9085 & 42.82073 & NL & 22 & 7.92132 & 69 & 39 \\
\hline & & & & & 354.25 & 3.43515 & 95.731 & 73.212 \\
\hline 101 & 44 & 159.2449 & 39.39046 & $\mathrm{NL}$ & 43 & 3 & 13 & 25 \\
\hline & & & & & 358.35 & 3.35384 & 103.51 & 77.366 \\
\hline 101 & 43 & 167.0458 & 40.43756 & $\mathrm{NL}$ & 66 & 6 & 27 & 25 \\
\hline & & & & & 353.31 & 0.93579 & 86.821 & 75.030 \\
\hline 98 & 46 & 159.0752 & 42.18769 & $\mathrm{NL}$ & 89 & 48 & 29 & 47 \\
\hline & & & & & 11.452 & 5.09948 & 159.08 & 83.968 \\
\hline 105 & 40 & 188.4846 & 39.8173 & $\mathrm{NL}$ & 67 & 3 & 67 & 96 \\
\hline & & & & & 345.22 & 4.07082 & 87.251 & 71.139 \\
\hline 94 & 44 & 148.6892 & 38.23916 & $\mathrm{NL}$ & 63 & 8 & 44 & 87 \\
\hline & & & & & 356.25 & 3.43515 & 97.731 & 73.212 \\
\hline 103 & 44 & 161.2449 & 39.39046 & $\mathrm{NL}$ & 43 & 3 & 13 & 25 \\
\hline & & & & & 348.86 & 6.12134 & 100.64 & 73.880 \\
\hline 95 & 41 & 155.6451 & 37.15013 & $\mathrm{NL}$ & 67 & 8 & 99 & 76 \\
\hline & & & & & 14.336 & 4.25934 & 143.26 & 83.240 \\
\hline 110 & 41 & 189.4513 & 40.51705 & $\mathrm{NL}$ & 68 & 5 & 73 & 7 \\
\hline & & & & & 193.35 & 7.87092 & 71.011 & 75.511 \\
\hline 114 & 54 & 179.4935 & 51.39356 & $\mathrm{NL}$ & 32 & 4 & 01 & 01 \\
\hline
\end{tabular}




\begin{tabular}{|c|c|c|c|c|c|c|c|c|}
\hline 110 & 58 & 183.3594 & 56.8883 & $\mathrm{NL}$ & $\begin{array}{r}193.49 \\
26 \\
\end{array}$ & $\begin{array}{r}12.5662 \\
4 \\
\end{array}$ & $\begin{array}{r}45.727 \\
19 \\
\end{array}$ & $\begin{array}{r}75.236 \\
79 \\
\end{array}$ \\
\hline & & & & & 197.86 & 8.49618 & 62.033 & 78.236 \\
\hline 115 & 54 & 188.3015 & 52.8186 & $\mathrm{NL}$ & 83 & 4 & 21 & 49 \\
\hline & & & & & 197.74 & 13.4568 & 51.390 & 73.963 \\
\hline 115 & 59 & 186.101 & 57.58045 & $\mathrm{NL}$ & 68 & 9 & 74 & 85 \\
\hline & & & & & 192.16 & 4.92411 & 44.198 & 84.196 \\
\hline 105 & 50 & 188.7914 & 49.83395 & $\mathrm{NL}$ & 22 & 4 & 38 & 88 \\
\hline & & & & & 182.82 & 10.4806 & 41.958 & 76.586 \\
\hline 100 & 56 & 172.4987 & 54.73026 & $\mathrm{NL}$ & 67 & 3 & 8 & 5 \\
\hline & & & & & 197.15 & 5.92288 & 45.034 & 83.306 \\
\hline 110 & 51 & 193.6596 & 50.82796 & $\mathrm{NL}$ & 75 & 6 & 47 & 21 \\
\hline & & & & & 197.83 & 10.9531 & 30.945 & 78.761 \\
\hline 110 & 56 & 194.6459 & 55.88376 & $\mathrm{NL}$ & 98 & 1 & 74 & 32 \\
\hline & & & & & 193.21 & 5.41863 & 71.127 & 79.874 \\
\hline 111 & 51 & 183.8355 & 49.71766 & $\mathrm{NL}$ & 09 & 9 & 04 & 68 \\
\hline & & & & & 209.57 & 5.98071 & 44.250 & 83.819 \\
\hline 121 & 51 & 207.8239 & 50.95692 & $\mathrm{NL}$ & 82 & 4 & 48 & 22 \\
\hline & & & & & 208.28 & 7.99502 & 34.064 & 81.964 \\
\hline 119 & 53 & 207.3387 & 52.98842 & $\mathrm{NL}$ & 6 & 4 & 78 & 67 \\
\hline & & & & & 193.53 & 14.9778 & 20.441 & 74.917 \\
\hline 105 & 60 & 191.0049 & 59.9396 & $\mathrm{NL}$ & 62 & 7 & 97 & 64 \\
\hline & & & & & 197.17 & & 73.819 & 86.496 \\
\hline 110 & 47 & 194.1458 & 46.85054 & $\mathrm{NL}$ & 11 & 1.92778 & 96 & 52 \\
\hline & & & & & 190.43 & 7.87568 & 37.640 & 81.159 \\
\hline 104 & 53 & 185.7286 & 52.71163 & $\mathrm{NL}$ & 3 & 4 & 18 & 18 \\
\hline & & & & & 193.83 & 10.9531 & 26.945 & 78.761 \\
\hline 106 & 56 & 190.6459 & 55.88376 & $\mathrm{NL}$ & 98 & 1 & 74 & 32 \\
\hline & & & & & 346.27 & 0.28293 & 77.064 & 70.280 \\
\hline 95 & 48 & 147.7117 & 41.46382 & NL & 52 & 65 & 56 & 44 \\
\hline & & & & & 208.29 & 2.99540 & 42.250 & 86.913 \\
\hline 119 & 48 & 207.5057 & 47.99031 & $\mathrm{NL}$ & 19 & 8 & 36 & 62 \\
\hline & & & & & 28.585 & 1.01714 & 154.78 & 88.278 \\
\hline 120 & 44 & 207.2207 & 43.9663 & $\mathrm{NL}$ & 69 & 7 & 59 & 13 \\
\hline & & & & & 203.29 & 1.99548 & 43.436 & 87.874 \\
\hline 114 & 47 & 202.5339 & 46.99064 & $\mathrm{NL}$ & 25 & 4 & 04 & 62 \\
\hline & & & & & 9.7500 & 4.14597 & 146.12 & 84.281 \\
\hline 104 & 41 & 186.0717 & 40.72771 & $\mathrm{NL}$ & 88 & 6 & 02 & 08 \\
\hline & & & & & 13.466 & 0.10901 & 105.23 & 86.465 \\
\hline 107 & 45 & 189.9468 & 44.78239 & $\mathrm{NL}$ & 72 & 31 & 17 & 04 \\
\hline & & & & & 201.16 & & 66.681 & 85.827 \\
\hline 114 & 48 & 198.034 & 47.84522 & $\mathrm{NL}$ & 9 & 2.92656 & 27 & 47 \\
\hline & & & & & 13.638 & 3.33427 & 132.52 & 83.122 \\
\hline 110 & 42 & 187.9687 & 41.36797 & $\mathrm{NL}$ & 36 & 3 & 11 & 43 \\
\hline & & & & & 6.9447 & 1.42766 & 108.52 & 82.924 \\
\hline 104 & 44 & 180.227 & 43.16525 & $\mathrm{NL}$ & 6 & 3 & 84 & 76 \\
\hline
\end{tabular}




\begin{tabular}{|c|c|c|c|c|c|c|c|c|}
\hline 106 & 64 & 153.3347 & 56.44415 & NL & $\begin{array}{r}179.98 \\
65 \\
\end{array}$ & $\begin{array}{r}16.2178 \\
6 \\
\end{array}$ & $\begin{array}{r}53.266 \\
2 \\
\end{array}$ & $\begin{array}{r}64.058 \\
45 \\
\end{array}$ \\
\hline & & & & & 170.92 & 17.6927 & 30.566 & 67.497 \\
\hline 92 & 64 & 150.5651 & 60.24648 & NL & 47 & 5 & 97 & 51 \\
\hline & & & & & 168.21 & 4.45189 & 66.971 & 68.235 \\
\hline 97 & 53 & 146.7471 & 45.36436 & NL & 66 & 5 & 36 & 7 \\
\hline & & & & & 169.06 & 8.31480 & 62.108 & 63.384 \\
\hline 100 & 58 & 142.5472 & 47.25919 & NL & 5 & 4 & 18 & 22 \\
\hline & & & & & 183.35 & 0.71634 & 86.269 & 84.209 \\
\hline 99 & 46 & 177.5625 & 45.42556 & NL & 19 & 51 & 53 & 55 \\
\hline & & & & & & 24.9744 & 6.3406 & 64.945 \\
\hline 93 & 70 & 177.1702 & 69.90432 & NL & 181.44 & 1 & 88 & 18 \\
\hline & & & & & 185.42 & 25.9740 & 10.220 & 63.946 \\
\hline 97 & 71 & 180.8778 & 70.89889 & NL & 7 & 4 & 98 & 82 \\
\hline 99 & 76 & 189 & 76 & NL & 189 & 31 & 9 & 59 \\
\hline & & & & & 150.76 & 15.6615 & 48.233 & 37.740 \\
\hline 95 & 76 & 106.4749 & 38.5864 & NL & 69 & 1 & 78 & 26 \\
\hline & & & & & 168.09 & 41.9668 & 352.11 & 47.963 \\
\hline 80 & 87 & 136.2871 & 86.39496 & NL & 8 & 4 & 21 & 18 \\
\hline & & & & & 211.39 & & 95.241 & 76.795 \\
\hline 132 & 52 & 198.4803 & 49.56657 & NL & 78 & 5.90521 & 73 & 2 \\
\hline & & & & & 171.98 & 34.6377 & 6.5308 & 54.484 \\
\hline 88 & 80 & 142.7363 & 77.8139 & NL & 79 & 4 & 59 & 8 \\
\hline
\end{tabular}




\section{VITA}

Georgina Rodriguez Gonzalez is Mexican born geoscientist whose research has focused on structural geology. After finishing her high school education in Chihuahua city, she began her undergraduate studies at the University of Texas at El Paso in 2012 and received a bachelor's in Geological Sciences in 2017. Within the same year she began working towards a master's degree in Geological Sciences at the University of Texas at El Paso. Her research took place in southern New Mexico and western Texas where she studied faults produced by the Rio Grande rift. Her field word concluded in the summer of 2018 and from thereon she focused on presenting her research at several conferences and writing a master's thesis. She defended her master's thesis, became a master's candidate and concluded a certificate Geographic Information Systems in 2019. She was also awarded "Outstanding Graduate Student" of the Geological Sciences department in that same year.

In the short term, Georgina will focus on teaching at a community college. She enjoys introducing and guiding students into the Earth sciences. Further down the road, she plans on continuing her graduate education and obtaining at $\mathrm{PhD}$.

Contact Information: georginarod94@gmail.com 